\title{
Radiological Status of the \\ Ground-Water Beneath the \\ Hanford Project \\ January-December 1978
}

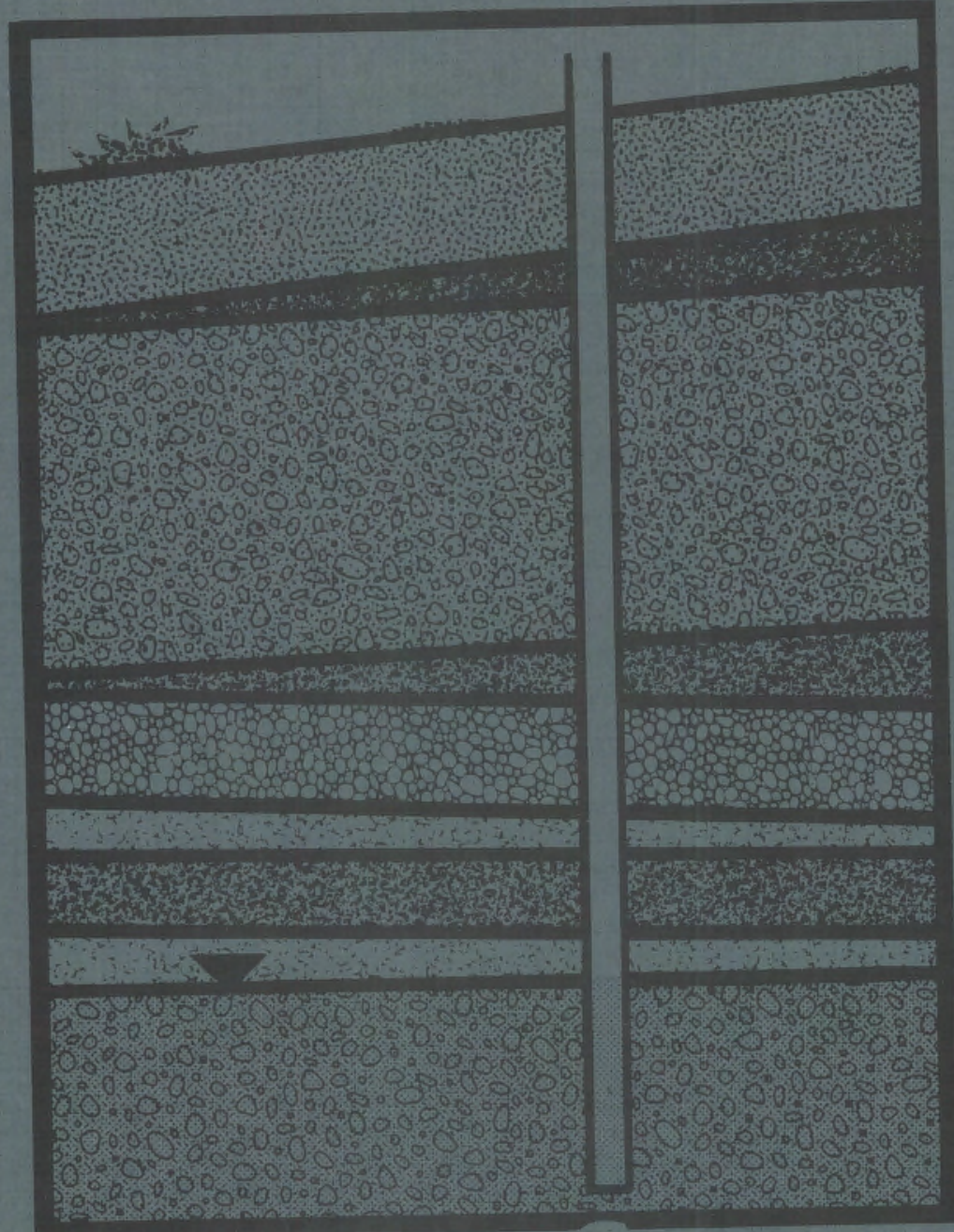

s.

\section{April 1979}

Prepared for the U.S. Department of Energy under Contract EY-76-C-06-1830

Pacific Northwest Laboratory

Operated for the U.S. Department of Energy

by Battelle Memorial Institute 


\title{
NOTICE
}

This report was prepared as an account of work sponsored by the United States Government. Neither the United States nor the Department of Energy, nor any of their employees, nor any of their contractors, or responsibility for their employees, makes any warranty, express or implied, or assumes any legal liability disclosed, or represents that its use would not infingefolness of any information, apparatus, product or process

The views, opinions and conclusions contained in this report are those of the contractor and do not necessarily represent those of the United States Government or the United States Department of Energy.

\author{
PACIFIC NORTHWEST LABORATORY \\ operated by \\ BATTELLE \\ for the \\ UNITED STATES DEPARTMENT OF ENERGY \\ Under Contract EY-76-C-06-1830
}
Printed in the United States of America Available from
National Technical Information Service
United States Department of Commerce
5285 Port Royal Road
Springfield, Virginia 22151

Price: Printed Copy $\mathbf{s}$

*; Microfiche $\$ \mathbf{\$ 3} .00$

$\begin{array}{cc} & \text { NTIS } \\ \text { *Pages } & \text { Selling Price } \\ 001-025 & \$ 4.00 \\ 026-050 & \$ 4.50 \\ 051-075 & \$ 5.25 \\ 076-100 & \$ 6.00 \\ 101-125 & \$ 6.50 \\ 126-150 & \$ 7.25 \\ 151-175 & \$ 8.00 \\ 176-200 & \$ 9.00 \\ 201-225 & \$ 9.25 \\ 226-250 & \$ 9.50 \\ 251-275 & \$ 10.75 \\ 276-300 & \$ 11.00 \\ & \end{array}$




\section{5}

RADIOLOGICAL STATUS OF THE GROUND-WATER BENEATH THE HANFORD PROJECT

JANUARY-DECEMBER 1978

P. A. Eddy

Apri1, 1979

Prepared for U.S. Department of Energy under Contract EY-76-C-06-1830

Pacific Northwest Laboratory

Richland, washington 99352 


.




\section{SUMMARY}

This report is one of a series prepared annually for the Department of Energy, to provide an evaluation of the status of ground-water contamination. resulting from Hanford's onsite discharges.

Data collected during 1978 describe the movement of major plumes $\left(\beta_{t}\right.$, $3_{\mathrm{H}}, \mathrm{NO}_{3}$ ) that respond to the influences of ground-water flow, ionic dispersion and radioactive decay. The total beta piume continues to recede, with the exception of a beta source that is beginning to show up in the 300 Area, a result of minor spilis and leaks which have occurred during the operating i ife of the 300 Area.

The tritium plume continues to expand and is mapped as having reached the Columbia River, although its contribution to the river cannot be distinguished from that attributable to atmospheric fallout. The plume now shows much the same configuration as in 1977. The nitrate plume shows genera? stability relative to its size with concentrations in the vicinity of the 100-H Area continuing to be high as a result of leaks from the evaporation facility.

The results of a study to determine the vertical distribution of contaminants in the Hanford ground-water system indicate that the majority of contaminants are stratified in the upper portions of the unconfined aquifer. 

CONTENTS

\begin{tabular}{|c|c|c|c|c|c|c|c|c|c|c|c|c|}
\hline SUMMARY & - & $\cdot$ & · & $\cdot$ & $\cdot$ & $\cdot$ & . & - & $\cdot$ & . & - & $\mathrm{iii}$ \\
\hline LIST OF FIGURES & - & - & . & . & - & . & . & - & - & $\cdot$ & - & vii \\
\hline LIST OF TABLES . & - & . & $\cdot$ & - & . & . & - & - & . & $\theta^{\circ}$ & - & vii \\
\hline INTRODUCTION & . & . & . & . & . & . & . & . & . & & . & \\
\hline BACKGROUND & . & . & - & . & . & . & . & . & . & 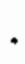 & . & \\
\hline DISPOSITION OF & WAST & & . & $\cdot$ & . & $\cdot$ & · & • & . & & - & \\
\hline MONITORING AND & WELL & & - & . & . & - & - & - & - & & - & \\
\hline SAMPLING AND AN & NALYS & & . & . & - & . & . & . & . & & · & \\
\hline EVALUATION OF GROUND & D-WAT & ER SU & QVEIL: & LANCE & DATA & . & - & - & . & & . & \\
\hline GROSS BETA $\left(\beta_{t}\right)$ & ) $\mathrm{CON}$ & ICENTR & ATION & IN G & ROUND & WATER & & . & . & & $\cdot$ & \\
\hline DEFINITION OF G & GROSS & BETA & CONTI & RIBUT & TORS & . & · & . & $\cdot$ & $\cdot$ & . & 12 \\
\hline TRITIUM $\left({ }^{3} \mathrm{H}\right) \mathrm{CO}$ & ONCEN & ITRATI & ON IN & THE & UNCONF & FINED & GROUN & ND WA & TER & & . & 15 \\
\hline NITRATE $\left(\mathrm{NO}_{3}{ }^{-}\right)$ & CONC & ENTRA & IION & IN TH & HE UNCO & ONF INE & ED GRO & OUND & WATER & 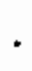 & - & 20 \\
\hline ADDITIONAL CONTAMINA & ANTS & IN TH & GROI & UND $W$ & JATER & $\cdot$ & . & · & • & $\cdot$ & - & 25 \\
\hline SPECIAL ANALYSE & ES FO & $\mathrm{R} I O D$ & {$[N E-1$} & & . & - & . & . & . & $\theta^{*}$ & & 25 \\
\hline THERMAL CONTAM & INAT I & & • & . & · & • & * & · & . & & - & 26 \\
\hline RADIOLOGICAL IMPACT & . & . & . & . & . & . & . & - & . & • & • & 29 \\
\hline GROUND WATER & $\cdot$ & . & $\cdot$ & - & - & . & $\cdot$ & - & . & • & - & 29 \\
\hline COLUMBIA RIVER & - & $\cdot$ & - & . & . & - & . & . & $\cdot$ & $\cdot$ & . & 29 \\
\hline QUAL ITY CONTROL & . & - & - & . & . & . & . & - & . & & & 32 \\
\hline REFERENCES & - & - & . & . & - & - & • & - & $\cdot$ & $\cdot$ & $\cdot$ & 33 \\
\hline APPENDIX A & . & - & - & - & - & . & $\cdot$ & - & - & - & & A- 1 \\
\hline APPENDIX B & . & - & - & - & - & - & . & • & . & & $\theta$ & $B-1$ \\
\hline APPENDIX C & . & . & . & . & . & . & . & . & . & . & & $C-1$ \\
\hline
\end{tabular}




\section{FIGURES}

1. The Hanford Site . . . . . . . . . . 3

2. Gross Beta Distribution in Unconfined Ground Water . . . 9

3. Concentration History for Total Beta Activity in Well 6-34-42 . 10

4. Concentration History for Total Beta Activity in We17 6-38-70 . 11

5. Concentration History for Total Beta Activity in Well 6-26-15 . 12

6. Tritium Distribution in Unconfined Ground Water . . . . 16

7. Concentration History for Tritium in Well 6-15-26 . . . . 17

8. Concentration History for Tritium in We11 6-32-22 . . . . 17

9. Concentration History for Tritium in We11 6-26-15. . . . 18

10. Concentration History for Tritium in We11 6-9-E2 . . . . 19

11. Concentration History for Tritium in Wel1 6-2-3 . . . . 19

12. Concentration History for Tritium in Well 6-87-55 . . . . 20

13. Nitrate Ion Distribution in Unconfined Ground water . . . 21

14. Concentration History for Nitrate in WeTl 1-H3-1 . . . . 22

15. Concentration History for Nitrate in Well 1-H4-3 . . . . 22

16. Concentration History for Nitrate in Well 6-34-42 . . . . 23

17. Concentration History for Nitrate in Well 6-17-5. . . . . 24

18. Location of Sample Points for I-129 Analysis . . . . . 26

19. Distribution of Ground-Water Temperatures Heasuredin
January 1979 . . . . . 27

20. Upstream and Downstream Concentration of Radionuclides

\section{$\underline{\text { TABLES }}$}

1. Lower Analytical Detection Limit and Lowest Applicable Concentration Guides on Drinking Water ReguTations . . . 7

2. Numerical Data on the Routine Ground-Water Monitoring

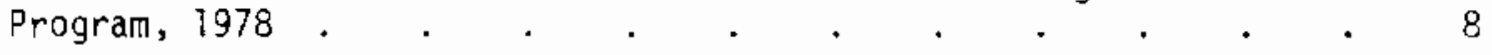

3. Comprehensive Radiochemical Analys is of Three Wells . . . 13

4. ${ }^{129} \mathrm{I},{ }^{60} \mathrm{Co}$, and ${ }^{106} \mathrm{Ru}$ Concentrations . . . . . 25 


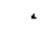

,

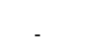




\section{INTRODUCTION}

Surveillance of ground water on the Hanford Site is one facet of the comprehensive Environmental Monitoring Program designed to evaluate existing and potential pathways of exposure to contamination from site operations. The objectives of the ground-water monitoring program conducted by the Pacific Northwest Laboratory (PNL) for the U.S. Department of Energy (DOE), are to measure and report the concentration and distribution of radioactive and other chemical constituents in the ground water, and to determine movement and transport of contaminants with time and the impact of contamination on man's environs.

All routine ground-water samples for 1978 were taken by P:NL's Environmental Evaluations section and were analyzed by the Technical Analysis Section. The U.S. Geological Survey, with the aid of the Geosciences Section of PNL, collected and comprehensively analyzed samples from specific wells. Program overview and coordination was provided by the Environmental Evaluations Section.

RockweII Hanford Operations (RHO) is DOE's prime contractor for chemical processing and waste management activities on the Hanford Site. Rockweli Hanford Operations is responsible for operations within the site's 200 Areas, and conducts a comprehensive sampling and analysis program in these areas. With the exception of a few analyses, data from the RHO program are not inciuded in this report. 


\section{BACKGROUND}

Operations on the Hanford Site since 1944 have resulted in the disposal of large volumes of low-level liquid radioactive wastes and contaminated cooling water to the ground. Figure 1 shows the location and layout of the site. Most of the liquid wastes have been disposed of to the ground at the chemical separation areas (200 Areas) located on a plateau near the center of the site. Smaller amounts of wastes have been released at the reactor sites (100 Areas) located adjacent to the Columbia River, and at the laboratory and fuel fabrication area (300 Area). Only one reactor and its associated disposal facility (in the 100-N Area) are currently in operation. The disposal of liquid waste to the ground has been greatly reduced in the past several years because of the deactivation of all except the iN Reactor at Hanford, the cessation of reactor fuel processing, and the improved treatment of several waste streams.

\section{DISPOSITION OF WASTES}

Liquid wastes disposed of to the ground percolate laterally and downard through 150 to 300 feet $(50$ to $100 \mathrm{~m}$ ) of unconsolidated glaciofluvial and lacustrine sands, silts and gravel overlying the unconfined ground water. As the wastes move through this sedimentary material, adsorption and ion exchange reactions take place between the minerals in the sediments and the materiais in the liquid waste. Some of the longer-lived and more hazardous radionuclides such as strontium-90 ( $\left.{ }^{90} \mathrm{Sr}\right)$, cesium- $137\left({ }^{137} \mathrm{Cs}\right)$, and plutonium-239 ( $\left.{ }^{239} \mathrm{Pu}\right)$ have favorable ion exchange characteristics and are effectively removed from the liquid as it percolates downward through the unsaturated soil column. 0ther radionuclides such as ruthenium-106 $\left({ }^{106} \mathrm{Ru}\right)$, colbalt-60 $\left({ }^{60} \mathrm{Co}\right)$, technetium-99 $\left({ }^{99} \mathrm{TC}\right)$, tritium $\left({ }^{3} \mathrm{H}\right)$, and nonradioactive materials such as nitrate $\left(\mathrm{NO}_{3}{ }^{-}\right)$have poor ion exchange characteristics and move through the unsaturated column at varying rates until they eventually enter the ground water. Once in the ground water, the contaminants move in a general down-gradient direction with the ground water. As the contaminants move in the ground water, their concentration is reduced by radioactive decay, ion exchange, diffusion and hydrodynamic dispersion. 


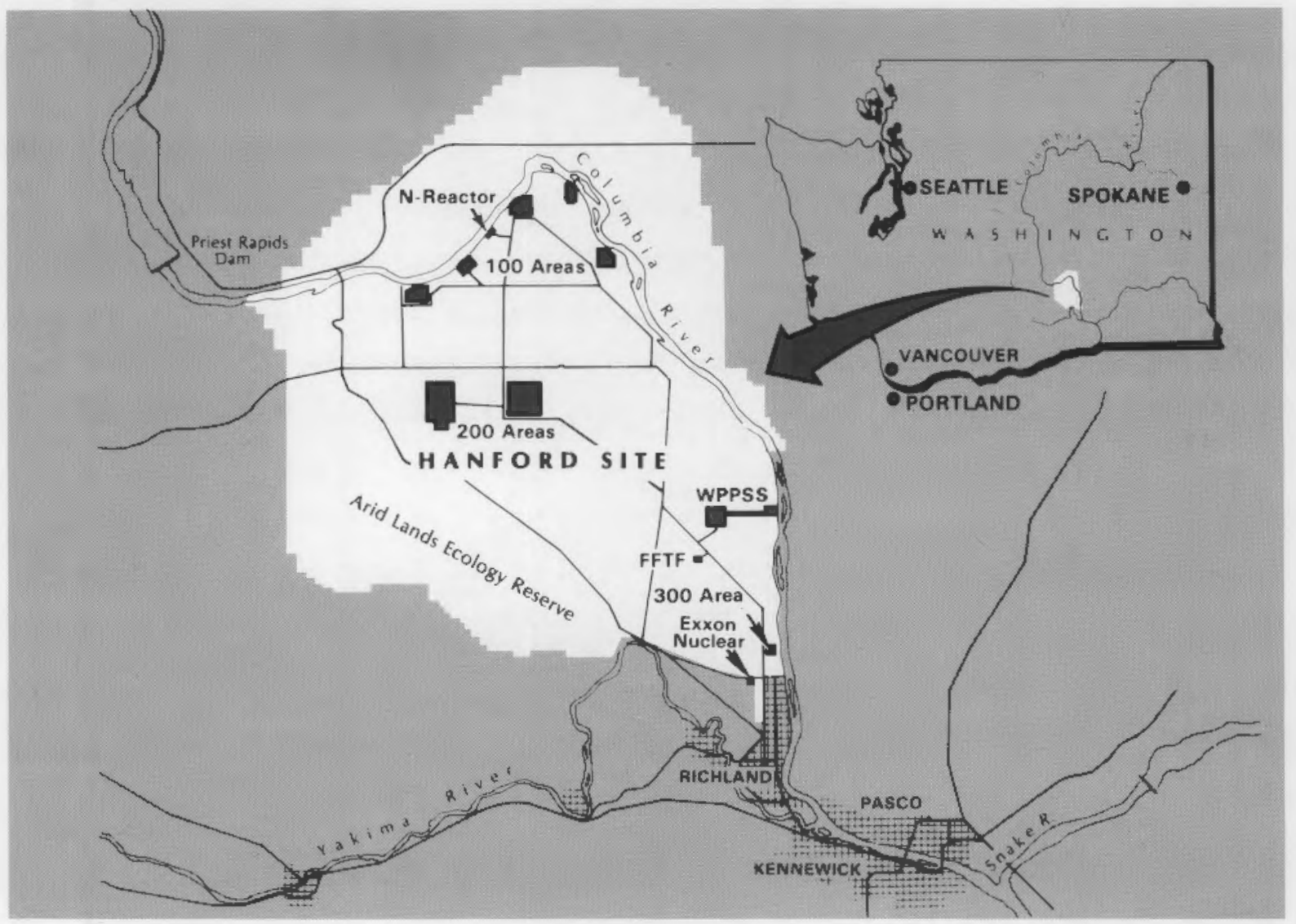

FIGURE 1. The Hanford Site 
During the past thirty-five years, the disposal of more than 160 billion gallons ( $26 \times 10^{11}$ liters) of process cooling water and about eight billion gallons ( $\sim 3 \times 10^{10}$ liters) of other liquid waste has changed the water table configuration. Ground-water mounds, created by the discharge of waste water, now exist near each of the chemical processing areas and in the $100-\mathrm{N}$ reactor area. Ground-water levels have changed continuously over the years, depending upon variations in the volume and location of waste water discharged to the ground. The movement of the ground water and its associated contaminants has also changed with time, reflecting the variation in waste water discharge.

\section{MONITORING AND WELLS}

Over 700 cased monitoring wells (McGhan and Damschen 1977) have been drilled to water since the beginning of the disposal operations at the Hanford Site. These structures provide a means of obtaining water samples and conducting in-well investigations.

There are basically three aquifers which are monitored at the Hanford Site. The first or lowest is an aquifer in the consolidated basalt. When a well is drilled into this aquifer an artesian flow (water under greater than atmospheric pressure) is generally encountered, which causes the water level in the well to rise. The second aquifer is encountered by wells drilled into a semiconsolidated material overlying the basalt. This aquifer is also generally artesian. The third and probably the most important aquifer at the Hanford Site is the unconfined aquifer under atmospheric pressure which covers the artesian aquifers and the unconsolidated material near the surface. This aquifer appears to have most of the contaminates in it and is monitored far more heavily than the deeper aquifers. Wells are generally drilled a few tens of feet below the top of the aquifer and samples are taken from this bottom zone. Most of the wells drilled at Hanford are multipurpose structures; that is, they are used to obtain geological and hydrologic information before they become sampling structures.

In order to be a structure that will be useful in monitoring, a well should be perforated along its entire length below the water table to allow 
the water in the aquifer to flow through the casing in a direction normal to the well at all depths. However, since the heterogeneity of the sediments beneath the Hanford Site prevents this, each well structure on the site must be evaluated individually as a monitoring facility.

For the 1978 routine ground-water monitoring program, 289 wells were used. From these, 1746 well-water samples were taken to provide 5250 analytical results for use in evaluating the effects of site operations on ground water. (These figures do not include other contractor monitoring efforts in the Hanford Site.)

\section{SAMPLING AND ANALYSIS}

Well-water samples are obtained routinely from throughout the Hanford Site. The frequency of sampling may be monthly, quarterly, semi-annually, or annually depending on the well location and constituents to be analyzed. Some ground-water samples are collected just under the water surface of the unconfined aquifer by lowering a glass bottle enclosed in a steel bail. When contamination appears in a project well, the highest concentration is usually observed at the surface of the water table (Eddy et al. 1978). Submersible sampling pumps have been installed in most key wells to obtain a more representative sample of the water in the aquifer adjacent to the wel1 than is provided by a small-volume dipped sample. The submersible pump method prevents the possibility of cross contamination that may result from using a single bailer to sample several wel1s. At a few locations where appropriate well structures are available, samples are obtained from the confined aquifer zones. Some small diameter wells and piezometer tubes are sampled by the airlift method (Trescott and Pinder 1970).

Three substances, the radionuclides represented by total beta measurement (calculated as ${ }^{106} \mathrm{Ru},{ }^{3} \mathrm{H}, \mathrm{NO}_{3}{ }^{-}$), are readily transported in ground water with little decrease in concentration from adsorption or ion exchange. They can also be detected in ground water in concentrations that are low relative to guidelines published in the Concentration Guides ( $C G$ ) in Manual Chapter 0524 (U.S. Department Energy 1977), or in the State of Washington's drinking water regulations (40 CFR 141). Therefore, these substances are 
used as primary tracers to monitor the movement of contaminated ground water. In addition, samples from selected wells are routinely analyzed at less frequent intervals for the radionuclides ${ }^{90} \mathrm{Sr},{ }^{137} \mathrm{Cs}$, and ${ }^{60} \mathrm{Co}$. Total alpha emission is also determined. Selected samples are analyzed by gamma spectrometry to identify the mixture of radionuclides present. Standard radiometric and chemical methods are used to analyze the routine ground-water samples.

Other radionuclides such as ${ }^{129} \mathrm{I}$ and ${ }^{99}$ TC have been detected in the ground water beneath the Hanford Site. These radionuclides also make excellent tracers of ground-water contamination and are used for this purpose to a limited extent, but they generally occur in very low concentrations. Groundwater from several wells is analyzed for chemical parameters in order to monitor broader changes in water quality. Analyses for uranium $\left({ }^{238} U\right)$, fluoride $\left(F^{-}\right)$and total chromium $(\mathrm{Cr})$ are made on selected ground-water samples in and adjacent to the 300 Area, because the fuel fabrication waste water disposed of at this site contains these contaminants. 


\section{EVALUATION OF GROUND-WATER SURVEILLANCE DATA}

Radionuclide concentrations in the ground water beneath Hanford are evaluated in terms of their respective Concentration Guides (CGS) (U.S. Department of Energy 1977); radioactive materials are compared with drinking water regulations (DWR) promulgated by the EPA ( 40 CFR 141) as adopted by the State of Washington. The comparison between the actual concentration and the guidelines provides a conservative method of evaluating the potential significance of most waterborne materials. The CGs used in this report are those that apply to uncontrolled areas. Table 1 shows the detection 7 imit and applicable CG or DWR for various materials analyzed under the routine ground-water monitoring program.

TABLE 1. Lower Analytical Detection Limit and Lowest Applicable Concentration Guides or Drinking Water Regulations

\begin{tabular}{|c|c|c|}
\hline Analysis & Detection Limit ${ }^{(a)}$ & $\operatorname{CGs}^{(a)}$ \\
\hline$\beta_{t}\left(\right.$ as $\left.{ }^{106} \mathrm{Ru}\right)$ & 0.08 & ${ }_{N A}(b)$ \\
\hline Gross Alpha (as ${ }^{239} \mathrm{Pu}$ ) & 0.017 & NA \\
\hline${ }^{3} \mathrm{H}$ & 1.0 & 3,000 \\
\hline${ }^{60} \mathrm{Co}$ & 0.02 & 30 \\
\hline${ }^{90} \mathrm{Sr}$ & 0.03 & 0.3 \\
\hline $106_{\mathrm{Ru}}$ & 0.06 & 10 \\
\hline${ }^{125} \mathrm{Sb}$ & 0.06 & 100 \\
\hline${ }^{129} \mathrm{I}$ & $1 \times 10^{-8}$ & 0.06 \\
\hline $131 \mathrm{I}$ & 0.01 & 0.8 \\
\hline${ }^{137} C_{s}$ & 0.02 & 20 \\
\hline U (Natural) & 3.4 & $\begin{array}{c}20,000 \mathrm{pCi} / \mathrm{e} \\
\text { DWR }\end{array}$ \\
\hline $\mathrm{NO}_{3}^{-}$ & $0.5 \mathrm{mg} / \mathrm{l}$ & $45 \mathrm{mg} / \mathrm{l}$ \\
\hline $\mathrm{F}^{-3}$ & $0.08 \mathrm{mg} / \mathrm{l}$ & $1.8 \mathrm{mg} / \mathrm{l}$ \\
\hline $\mathrm{Cr}^{6+}$ & $3 \mathrm{mg} / \mathrm{h}$ & $0 \mu \mathrm{g} / \mathrm{l}$ \\
\hline
\end{tabular}

(a) $\mathrm{pCi} / \mathrm{ml}$ except where otherwise noted

(b) NA--Not Applicable. Significance of contaminations determined by specific radionuclide analysis. 
At the beginning of each report section dealing with a major contaminant, a map shows the distribution of that contaminant. The isopleths on the maps show concentration zones rather than discrete contours because the data do not justify the additional detail. Data from waste disposal operations and resultant ground-water contamination in the 200 Areas are not included in this report. However, data from the 200 Areas were used to provide continuity in the maps.

Appendix A contains tabular analytical data for 1978 on the average, maximum and minimum concentrations of the primary tracers (gross beta activity, tritium and nitrate ion). The data on the average concentrations of the primary tracers were used to generate the isopleth maps.

Table 2 shows the number of wells sampled, the number of samples taken, and the number of analyses made as part of the 1978 ground-water monitoring program for each area of the Hanford Site. The data shown in Appendices A (the primary tracers) and $B$ (other materials) were derived from analysis of the samples. The table does not account for any special samples taken.

TABLE 2. Numerical Data on the Routine Ground-Water Monitoring Program, 1978

\begin{tabular}{|c|c|c|c|}
\hline Area & $\begin{array}{c}\text { Number of } \\
\text { Wells Sampled }\end{array}$ & $\begin{array}{c}\text { Number of } \\
\text { Samples Taken }\end{array}$ & $\begin{array}{c}\text { Number of } \\
\text { AnaTyses Made }\end{array}$ \\
\hline 100 & 28 & 128 & 344 \\
\hline 200 & 21 & 84 & 252 \\
\hline 300 & 28 & 112 & 672 \\
\hline & 212 & 852 & 1908 \\
\hline & 289 & 1176 & 4352 \\
\hline
\end{tabular}

GROSS BETA $\left(\beta_{t}\right)$ CONCENTRATION IN THE GROUND WATER

Figure 2 shows the concentration and distribution of $\beta_{t}$ contamination in Hanford's unconfined ground water. Appendix A contains data on the primary tracers for ground-water samples collected during 1978. The configuration of the $\beta_{t}$ plume is static but the plume's general size has continued to recede slightiy since the last reporting period. The plume now extends southeasterly from the 200-E Area for about $12.5 \mathrm{~km}$ (7.8 miles). 


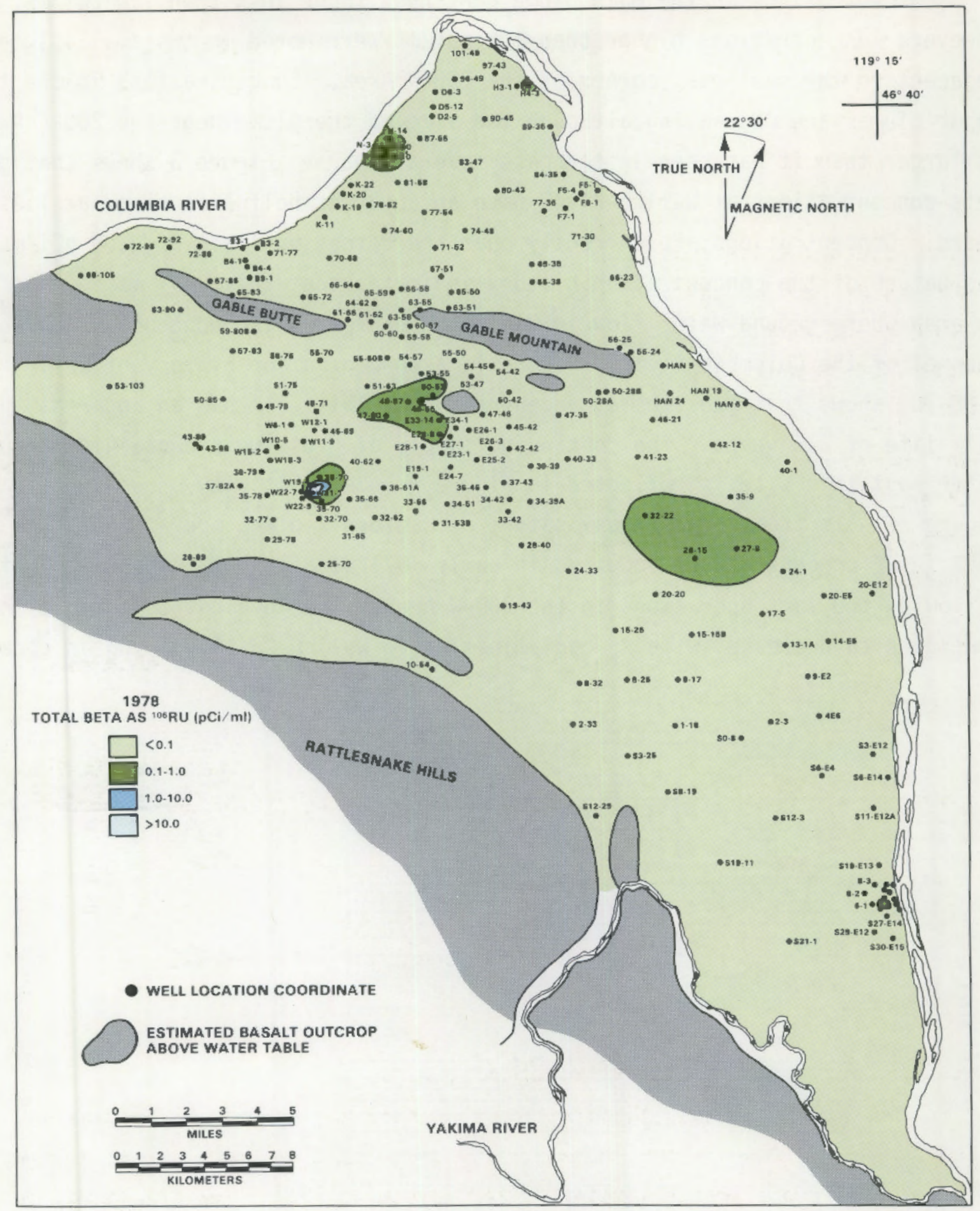

FIGURE 2. Gross Beta Distribution in Unconfined Ground Water 
Concentrations in the main plume continued to be less than $1.0 \mathrm{pCi} / \mathrm{ml}$. However, concentrations higher than $1.0 \mathrm{pCi} / \mathrm{ml}$ were noted in two small plumes adjacent to the southeast corner of the 200-W Area. Concentrations in the three major plumes are decreasing although the size of the plume near the 200-E Area is larger than it has been in the past several years. Figure 3 shows that gross beta concentrations at Well 6-34-42 have an apparent half life of about 1.3 years. Concentrations are currently near the detection 1 imit of $0.08 \mathrm{pCi} / \mathrm{ml}$. The nature of the concentration history indicates that this well is located in an area where ground-water flow is minimal, perhaps on the edge of an ancient channel of the Columbia River. Figure 4, a concentration history of Well 6-38-70, shows that gross beta concentration at this well has an apparent half life of 3.6 years. The continuing supply of gross beta-containing ground water past this site is reflected in Figure 4. Beta activity shown in this figure results from the cyclical nature of Hanford's plant operations. The peak in $\beta_{t}$ concentrations occurred in early 1971 at a level of about $1.5 \mathrm{pCi} / \ell$, following the last operations in the 200-W Area. The level of contamination continues to decrease, with $\beta_{t}$ contamination in Well 6-26-15 showing an apparent

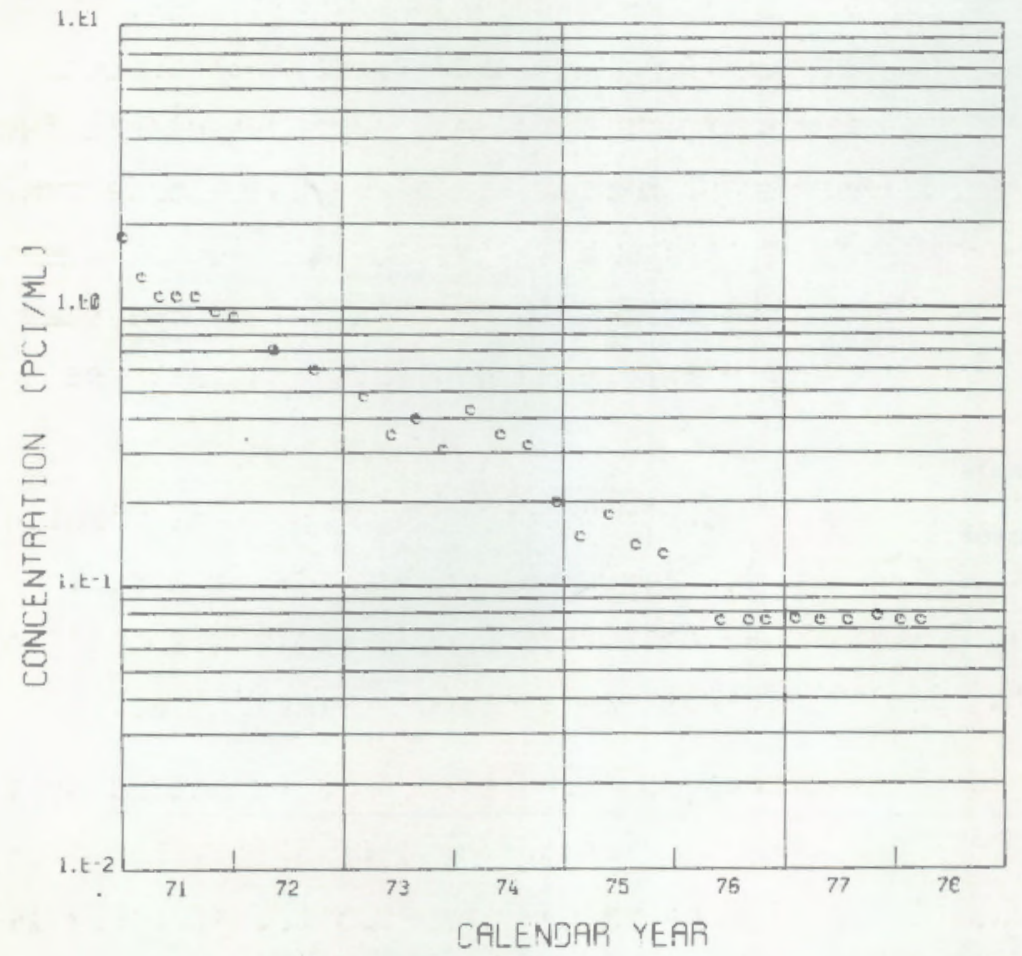

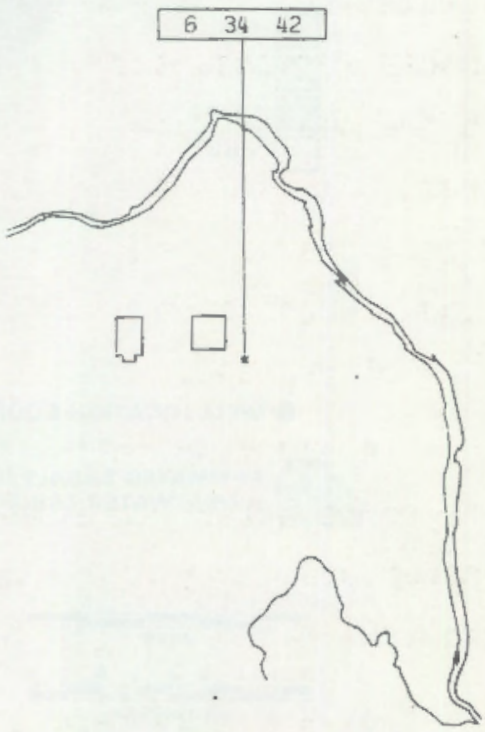

HANFORS RESERVATION

FIGURE 3. Concentration History for Total Beta Activity in Well 6-34-42 

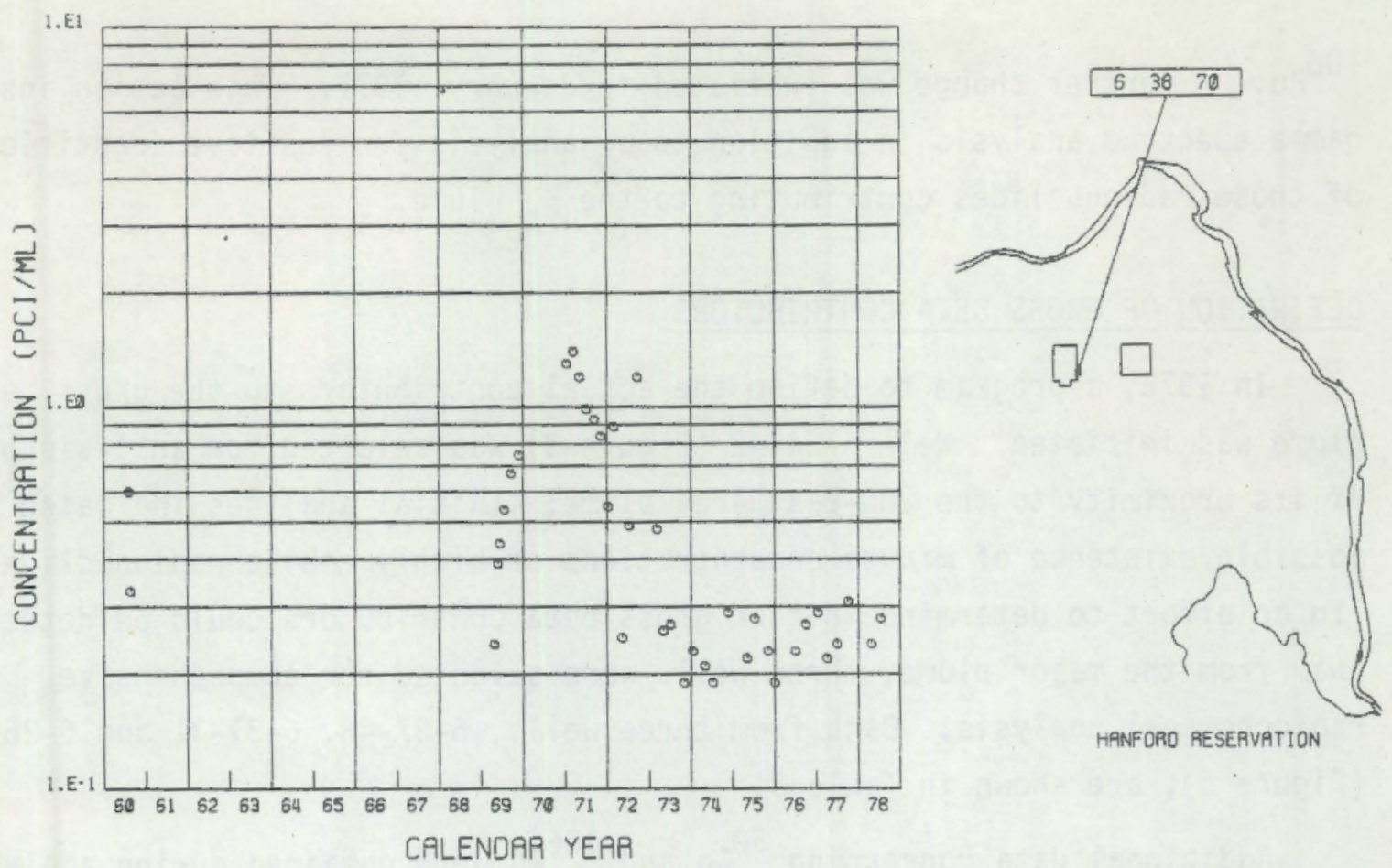

HANFORO RESERVATION

FIGURE 4. Concentration History for Total Beta Activity in Well 6-38-70

half life midway between those of Wel1s $6-34-42$ and $6-38-70$. Well $6-26-15$ is located near the extreme eastern edge of the gross beta plume. Gross beta concentrations at this site are expected to drop to less than detectable levels in the near future. Peaks in concentration histories can be used to determine travel times in the ground-water flow system. However, correlation of peaks and discharges is sometimes difficult because dispersion within the flow system tends to coalesce minor plumes from different release points and mask the true time of release.

In addition to the 200 Area plumes, contributors to the $\beta_{t}$ contamination of ground water are evident in the 100-B, 100-D and 100-H Areas from past operations; they are evident in the $100-\mathrm{N}$ Area from liquid waste disposal to the 1301-N trench; and in the 300 Area, from waste disposal facilities.

In 1973, the reporting of $\beta_{t}$ was changed. The change is reflected by a lowering of the apparent detection level. Prior to 1973, all analyses for $\beta_{t}$ were reported as ${ }^{106} \mathrm{Ru} /{ }^{106} \mathrm{Rd}^{h}$. Currently the values are reported strictly as 
${ }^{106} \mathrm{Ru}$. A further change was initiated in January, 1977. This action instituted gamma spectrum analysis in addition to $\beta_{t}$ analysis for positive identification of those radionuclides contributing to the $\beta_{t}$ plume.

\section{DEFINITION OF GROSS BETA CONTRIBUTORS}

In 1976, a program to define the actual contributors to the gross beta plume was initiated. Well 6-34-42 (Figure 3) was selected for analysis because of its proximity to the 200-East Area plume. Initial analyses indicated the possible existence of minute concentrations of highly mobile radionuclides.

In an effort to determine whether gross beta contributors could be detected away from the major plume, three wells were selected for comprehensive radiochemical analysis. Data from three wel1s, 6-37-43, 6-31-31 and 6-26-15 (Figure 5), are shown in Table 3.

Additional data concerning ${ }^{60} \mathrm{Co}$ and ${ }^{106} \mathrm{Ru}$ were obtained during analysis for ${ }^{129} \mathrm{I}$; these data are presented in a later section of this report. The low
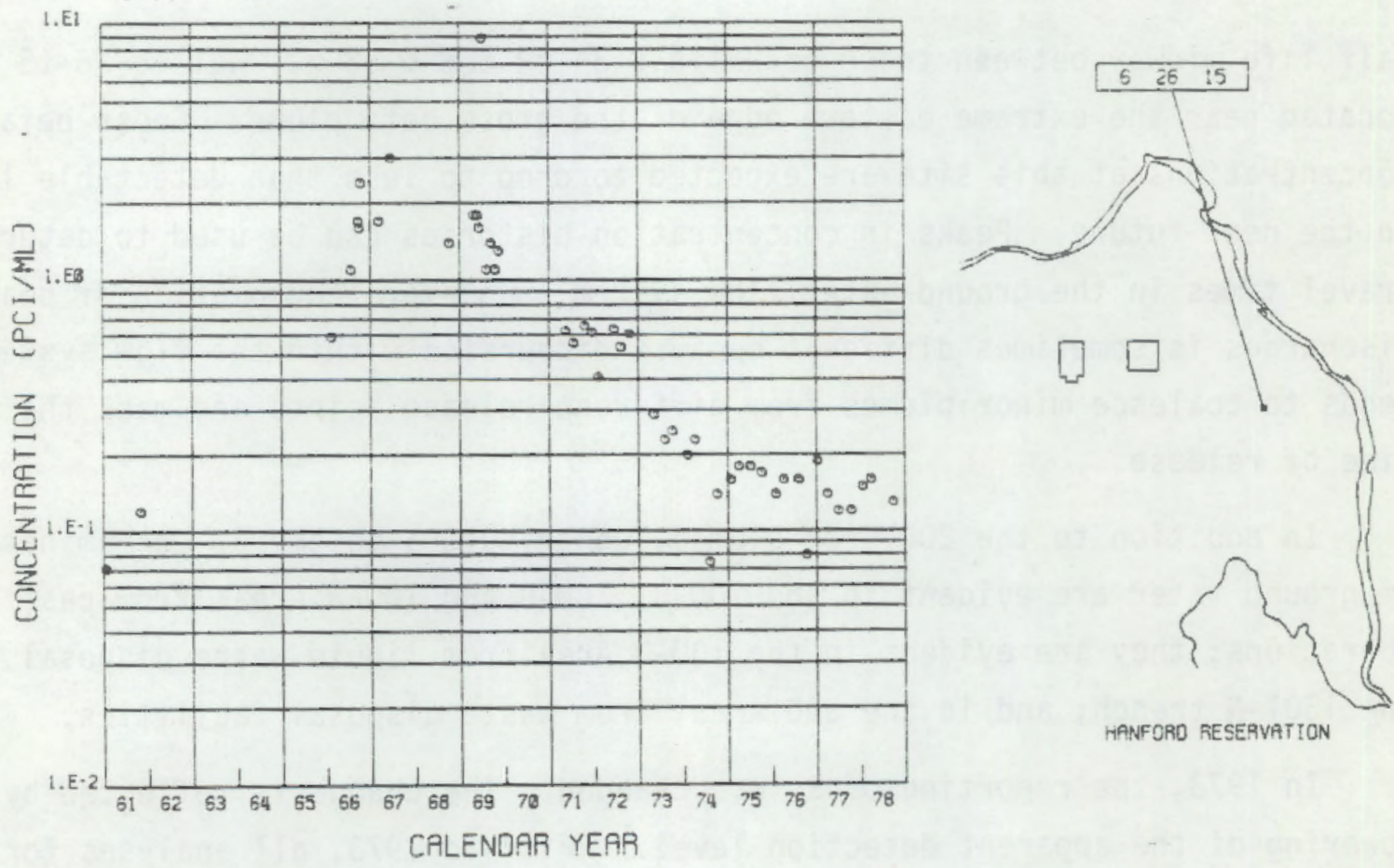

HANFORD RESERVATION

FIGURE 5. Concentration History for Total Beta Activity in Well 6-26-15 
TABLE 3. Comprehensive Radiochemical Analys is of Three Wells

\begin{tabular}{|c|c|c|c|c|c|c|c|c|c|c|}
\hline Well No. & ${ }^{22} \mathrm{Na}$ & ${ }^{54} \mathrm{Mn}$ & ${ }^{60} \mathrm{Co}$ & ${ }^{65} \mathrm{Zn}$ & ${ }^{95} z_{p}^{\prime}$ & ${ }^{95} \mathrm{Nb}$ & $106 \mathrm{Ru}$ & $108 \mathrm{~m}_{\mathrm{Ag}}$ & $110 \mathrm{~m}_{\mathrm{Ag}}$ & ${ }^{125} \mathrm{Sb}$ \\
\hline \multicolumn{11}{|l|}{$699-26-15$} \\
\hline Filters & $<0.0016$ & $<0.0014$ & 0.019 & $<0.0035$ & 0.0030 & 0.0032 & 0.019 & $<0.0011$ & $<0.0019$ & $<0.0042$ \\
\hline Ist Anion Bed & $<0.024$ & 0.042 & 53. - & $0.15 e$ & 0.060 & 0.037 . & 1.57. & $<0.019$. & $<0.050$. & $<0.057^{\circ}$ \\
\hline 2nd Anion Bed & $<0.0063$ & $<0.0066$ & 1.7 & 0.027 & $<0.017$ & $<0.012$ & 0.24 & $<0.0080^{\circ}$ & $<0.0096$ & $<0.014$ \\
\hline 1st Cation Bed & $<0.0047$ & $<0.0045$ & 0.15 & $<0.017$ & $<0.011$ & $<0.0040$ & 0.065 & $<0.0034$ & $<0.0055$ & $<0.010$ \\
\hline 2nd Cation Bed & $<0.0059$ & $<0.0070$ & 0.075 & $<0.011$ & $<0.0069$ & $<0.0099$ & 0.039 & $<0.0033$ & $<0.0051$ & $<0.0098$ \\
\hline Ist $\mathrm{Al}_{2} \mathrm{O}_{3}$ & $<0.0014$ & $<0.0016$ & 0.014 & $<0.0045$ & $<0.0039$ & $<0.0031$ & 0.027 & $<0.0016$ & $<0.0013$ & $<0.0064$ \\
\hline 2nd $\mathrm{Al}_{2} \mathrm{O}_{3}$ & $<0.0014$ & $<0.0029$ & 0.012 & $<0.0025$ & $<0.0039$ & $<0.0015$ & 0.022 & $<0.00097$ & $<0.0014$ & $<0.0030$ \\
\hline 3 rd $\mathrm{Al}_{2} \mathrm{O}_{3}$ & $<0.00091$ & $<0.0014$ & 0.0090 & $<0.0037$ & $<0.0021$ & $<0.0030$ & 0.016 & $<0.00094$ & $<0.0019$ & $<0.0042$ \\
\hline \multicolumn{11}{|l|}{$699-37-31$} \\
\hline Filters & $<0.0018$ & $<0.0028$ & 0.074 & $<0.0037$ & $<0.0017$ & $<0.0020$ & 0.011 & $<0.00091$ & $<0.0019$ & $<0.0056$ \\
\hline 1st Anion Bed & $<0.015$ & $<0.017$ & 20. & 0.094 & 0.038 & 0.024 & 2.77 & $<0.014$ & $<0.028$ & $<0.033$ \\
\hline 2nd Anion Bed & $<0.0056$ & $<0.013$ & 1.74 & $<0.033$ & $<0.011$ & $<0.0062$ & 0.44 & 0.0080 & $<0.014$ & $<0.015$ \\
\hline Ist Cation Bed & $<0.0036$ & 0.0029 & 0.14 & 0.014 & $<0.0094$ & $<0.0058$ & 0.036 & $<0.0025$ & $<0.0041$ & $<0.0076$ \\
\hline 2nd Cation Bed & $<0.0079$ & $<0.0050$ & 0.064 & -0.0090 & $<0.0052$ & $<0.0055$ & 0.037 & $<0.0028$ & 0.0038 & $<0.0080$ \\
\hline Ist $\mathrm{Al}_{2} \mathrm{O}_{3}$ & $<0.0019$ & $<0.0027$ & 0.011 & 0.0022 & $<0.0039$ & $<0.0026$ & 0.043 & $<0.0018$ & $<0.0014$ & $<0.0031$ \\
\hline 2nd $\mathrm{Al}_{2} \mathrm{O}_{3}$ & $<0.0011$ & $<0.0018$ & 0.012 & $<0.0054$ & $<0.0029$ & $<0.0021$ & 0.034 & $<0.0009$ ? & 0.0012 & $<0.0025$ \\
\hline $3 \mathrm{rd} \mathrm{Al} \mathrm{O}_{3}$ & $<0.0017$ & 0.0011 & 0.017 & $<0.0030$ & $<0.0019$ & $<0.0020$ & 0.039 & $<0.00093$ & $<0.0012$ & $<0.0025$ \\
\hline \multicolumn{11}{|l|}{$699-37-43$} \\
\hline Filters & $<0.0014$ & $<0.0018$ & 0.020 & $<0.0024$ & $<0.0017$ & $<0.0026$ & $<0.0093$ & $<0.0017$ & $<0.0021$ & $<0.0039$ \\
\hline Ist Anion Bed & $<0.0074$ & $<0.0034$ & 0.020 & $<0.019$ & $<0.0072$ & $<0.0069$ & 0.15 & $<0.0060$ & $<0.0060$ & $<0.014$ \\
\hline 2nd Anion Bed & $<0.0087$ & 0.0032 & 0.016 & 0.0080 & $<0.0069$ & $<0.0039$ & $<0.033$ & $<0.0032$ & $<0.0043$ & $<0.011$ \\
\hline Tst Cation Bed & $<0.0046$ & $<0.0035$ & $<0.0038$ & $<0.0086$ & $<0.0070$ & $<0.0075$ & $<0.031$ & $<0.0042$ & $<0.0044$ & $<0.012$ \\
\hline 2nd Cation Bed & $<0.0038$ & $<0.0051$ & $<0.0057$ & $<0.011$ & $<0.0056$ & $<0.0040$ & $<0.033$ & $<0.0041$ & $<0.0058$ & $<0.011$ \\
\hline 1st $\mathrm{Al}_{2} \mathrm{O}_{3}$ & $<0.0018$ & $<0.00092$ & $<0.0043$ & $<0.0025$ & $<0.0031$ & $<0.0024$ & $<0.0094$ & $<0.00088$ & $<0.0015$ & $<0.0028$ \\
\hline 2nd $\mathrm{Al}_{2} \mathrm{O}_{3}$ & $<0.0013$ & $<0.0022$ & $<0.0039$ & $<0.0031$ & $<0.0020$ & $<0.0011$ & $<0.0084$ & $<0.0011$ & $<0.0029$ & $<0.0036$ \\
\hline 3 rd $\mathrm{Al}_{2} \mathrm{O}_{3}$ & $<0.0013$ & $<0.0017$ & $<0.0059$ & $<0.0039$ & $<0.0044$ & $<0.0016$ & $<0.0093$ & $<0.00088$ & $<0.0016$ & $<0.0027$ \\
\hline
\end{tabular}


TABLE 3. Comprehensive Radiochemical Analysis of Three Wells (contd)

\begin{tabular}{|c|c|c|c|c|c|c|c|c|c|}
\hline Well No. & ${ }^{126} \mathrm{Sn} \cdot{ }^{126} \mathrm{Sb}$ & ${ }^{134} \mathrm{Cs}$ & ${ }^{137} \mathrm{Cs}$ & ${ }^{144} \mathrm{Ce}$ & ${ }^{152} \mathrm{Eu}$ & ${ }^{154} \mathrm{Eu}$ & ${ }^{155_{\mathrm{EU}}}$ & ${ }^{212} \mathrm{~Pb}\left({ }^{228} \mathrm{Th}\right)$ & ${ }^{214} \mathrm{~Pb}\left({ }^{226} \mathrm{Ra}\right)$ \\
\hline \multicolumn{10}{|l|}{$699-26-15$} \\
\hline Filters & $<0.0020$ & $<0.0016$ & 0.0034 & $<0.011$ & $<0.0036$ & 0.011 & $<0.0068$ & 0.029 & 0.0060 \\
\hline ist Anion Bed & $<0.025^{\circ}$ & $<0.035$ & 0.053 . & $0.19^{\circ}$ & $<0.058$ & $<0.24^{\circ}$ & $<0.059$ & $<0.0062$ & $<0.0012$ \\
\hline 2nd Anion Bed & $<0.0066$ & $<0.018<$ ? & $<0.0078$ & $<0.036$ & $<0.015$ & $<0.047$ & $<0.034$ & $<0.0050$ & $<0.0012$ \\
\hline Ist Cation Bed & $<0.0070$ & $<0.0091$ & $<0.0036$ & $<0.033$ & $<0.011$ & $<0.024$ & $<0.019$ & 0.022 • & 0.042 \\
\hline 2nd Cation Bed & $<0.0078$ & $<0.0069$ & $<0.0090$ & $<0.029$ & $<0.010$ & $<0.048$ & $<0.016$ & $<0.0047$ & 0.011 \\
\hline Ist $\mathrm{Al}_{2} \mathrm{O}_{3}$ & $<0.0018$ & $<0.0012$ & $<0.0022$ & $<0.015$ & $<0.0032$ & $<0.0064$ & $<0.0044$ & $<0.0014$ & $<0.0018$ \\
\hline 2nd $\mathrm{Al}_{2} \mathrm{O}_{3}$ & $<0.0020$ & $<0.0024$ & $<0.0017$ & $<0.0085$ & $<0.0031$ & $<0.0090$ & $<0.0040$ & $<0.0014$ & $<0.0025$ \\
\hline 3 d $\mathrm{Al}_{2} \mathrm{O}_{3}$ & $<0.0014$ & $<0.0017$ & $<0.00094$ & $<0.012$ & $<0.0052$ & $<0.013$ & $<0.0039$ & $<0.0031$ & $<0.0023$ \\
\hline \multicolumn{10}{|l|}{$699-31-31$} \\
\hline Filters & $<0.0019$ & $<0.0016$ & 0.0069 & $<0.0084$ & $<0.0031$ & $<0.0073$ & $<0.0052$ & 0.010 & 0.0038 \\
\hline Ist Anion Bed & $<0.020$ & $<0.034$ & 0.031 & 0.074 & $<0.063$ & $<0.14$ & $<0.035$ & 0.024 & $<0.0012$ \\
\hline 2nd Anion Bed & $<0.0050$ & $<0.0068$ & $<0.0092$ & $<0.033$ & $<0.014$ & $<0.045$ & $<0.017$ & $<0.0061$ & $<0.0044$ \\
\hline Ist Cation Bed & $<0.0057$ & $<0.0069$ & 0.0058 & $<0.024$ & $<0.0087$ & $<0.034$ & $<0.015$ & 0.0081 & 0.023 \\
\hline 2nd Cation Bed & $<0.0028$ & $<0.0055$ & $<0.0074$ & 0.024 & $<0.0076$ & $<0.022$ & $<0.018$ & $<0.0050$ & 0.0090 \\
\hline Ist $\mathrm{Al}_{2} \mathrm{O}_{3}$ & $<0.0011$ & 0.0007 & $<0.0013$ & $<0.0072$ & $<0.0027$ & $<0.0047$ & $<0.0046$ & $<0.0013$ & $<0.0022$ \\
\hline 2nd $\mathrm{Al}_{2} \mathrm{O}_{3}$ & $<0.0012$ & 0.0018 & $<0.0013$ & $<0.0088$ & $<0.0027$ & $<0.011$ & $<0.0041$ & $<0.00078$ & $<0.00051$ \\
\hline 3 rd $\mathrm{Al}_{2} \mathrm{O}_{3}$ & 0.0012 & 0.0018 & $<0.0011$ & $<0.0074$ & $<0.0028$ & $<0.0081$ & 0.0036 & $<0.000091$ & $<0.0014$ \\
\hline \multicolumn{10}{|l|}{$699-37-43$} \\
\hline Filters & $<0.0013$ & $<0.0030$ & 0.014 & $<0.0080$ & $<0.0034$ & $<0.0067$ & $<0.0063$ & 0.017 & 0.0094 \\
\hline Ist Anion Bed & 0.0066 & $<0.0053$ & $<0.0077$ & $<0.035$ & $<0.011$ & $<0.069$ & $<0.019$ & $<0.0062$ & $<0.0012$ \\
\hline 2nd Anion Bed & $<0.0065$ & $<0.0057$ & $<0.0053$ & $<0.0054$ & $<0.010$ & $<0.054$ & $<0.017$ & $<0.0084$ & $<0.0078$ \\
\hline Ist Cation Bed & $<0.0031$ & $<0.0058$ & $<0.0063$ & $<0.032$ & $<0.011$ & $<0.028$ & $<0.024$ & $<0.0064$ & 0.033 \\
\hline 2nd Cation Bed & $<0.0027$ & $<0.0031$ & $<0.0043$ & $<0.030$ & $<0.013$ & $<0.024$ & $<0.018$ & $<0.0090$ & 0.0054 \\
\hline Ist $\mathrm{Al}_{2} \mathrm{O}_{3}$ & $<0.0016$ & $<0.0009$ & $<0.00091$ & $<0.0077$ & $<0.0049$ & $<0.012$ & $<0.0062$ & $<0.0050$ & $<0.0012$ \\
\hline 2nd $\mathrm{Al}_{2} \mathrm{O}_{3}$ & $<0.0011$ & $<0.0012$ & $<0.0013$ & $<0.0077$ & $<0.0051$ & $<0.012$ & $<0.0057$ & $<0.0049$ & $<0.0034$ \\
\hline $3 \mathrm{rd} \mathrm{Al}{ }_{2} \mathrm{O}_{3}$ & $<0.0016$ & $<0.0017$ & $<0.00095$ & $<0.0082$ & $<0.0029$ & $<0.0082$ & $<0.0037$ & $<0.0026$ & $<0.00055$ \\
\hline
\end{tabular}


levels shown for these radionuclides were attainable only through special analytical techniques, and corroborate the data obtained to define the gross beta contributors.

\section{TRITIUM $\left({ }^{3} H\right)$ CONCENTRATION IN THE UNCONFINED GROUND WATER}

Because tritium enters the ground-water system as a part of the water molecule, it is carried along with the ground-water flow and remains almost unaffected by the geologic conditions that affect other radionuclides. Tritium, therefore, provides the most accurate and extensive overview of Hanford operations. Figure 6 shows the distribution of ${ }^{3} \mathrm{H}$ in the unconfined aquifer. Appendix A contains data concerning maximum, average and minimum concentrations for samples collected in 1978.

The configuration of the ${ }^{3} \mathrm{H}$ plume has changed somewhat in the past year. Concentrations of ${ }^{3} \mathrm{H}$ in we11 6-40-1 remain high and continue to indicate that the plume is nearing the Columbia River.

Tritium concentrations in wells within the plume show different responses dependent upon the geohydrology of the locale being monitored. Figure 7 shows a concentration history for Well 6-15-26. The apparent half life for ${ }^{3} \mathrm{H}$ in this well is about 10 years, slightly less than the actual half life. This rate of decay indicates that uncontaminated or at least less-contaminated water is reaching this we11. Figure 8 , a concentration history for We11-6-32-22, shows essentially the same thing; however, ground water containing slightly more elevated concentrations of ${ }^{3} \mathrm{H}$ is indicated by the apparent half 1 ife, which is greater than 12.3 years. The concentration history of ${ }^{3} \mathrm{H}$ in Wel1 6-26-15 (Figure 9) shows that, after peaking in 1969, concentrations of ${ }^{3} \mathrm{H}$ declined and reached an apparent equilibrium in about 1975. Ground-water flow in the vicinity of this well is such that concentrations are maintained near $1000 \mathrm{pCi} / \mathrm{ml}$.

Figure 10 shows that the tritium concentration in Well 6-9-E2 dropped through mid-1972 and has been increasing since then. The increase in ${ }^{3} \mathrm{H}$ concentration in 6-9-E2 matches closely that shown in Well 6-2-3 (Figure 11), which has rising ${ }^{3} \mathrm{H}$ concentrations starting about 1966 . These two wells 


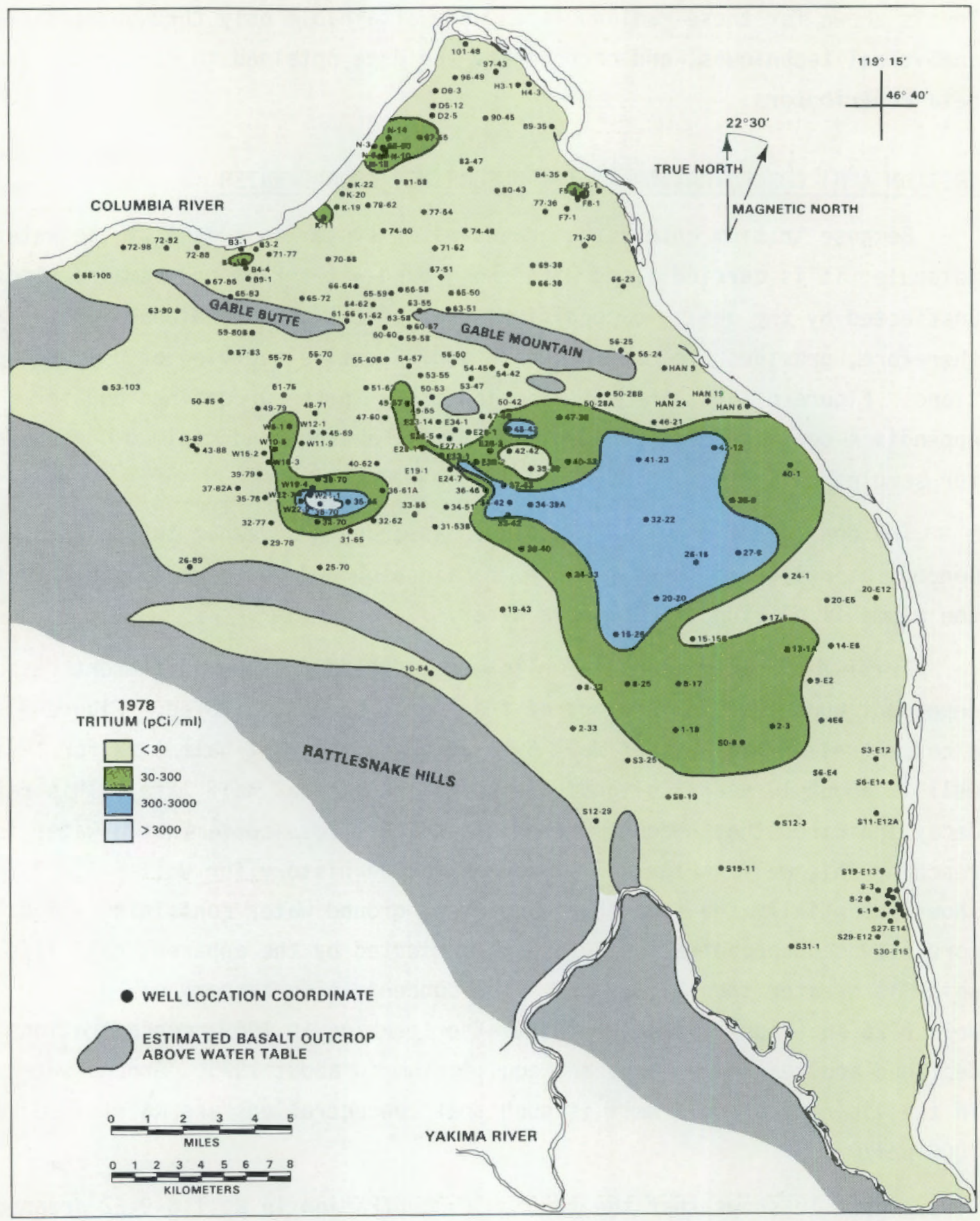

FIGURE 6. Tritium Distribution in Unconfined Ground Water 

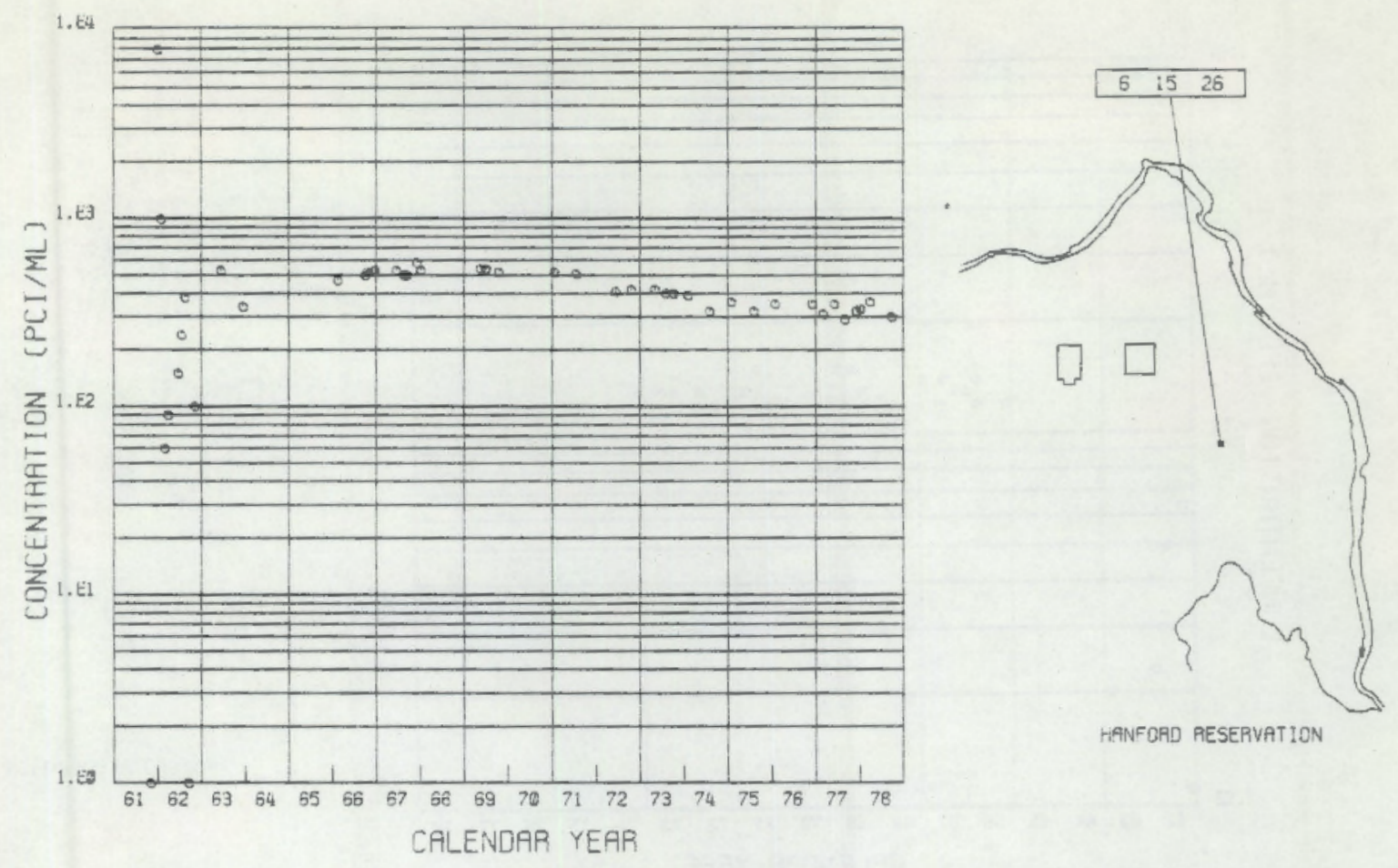

FIGURE 7. Concentration History for Tritium in We11 6-15-26
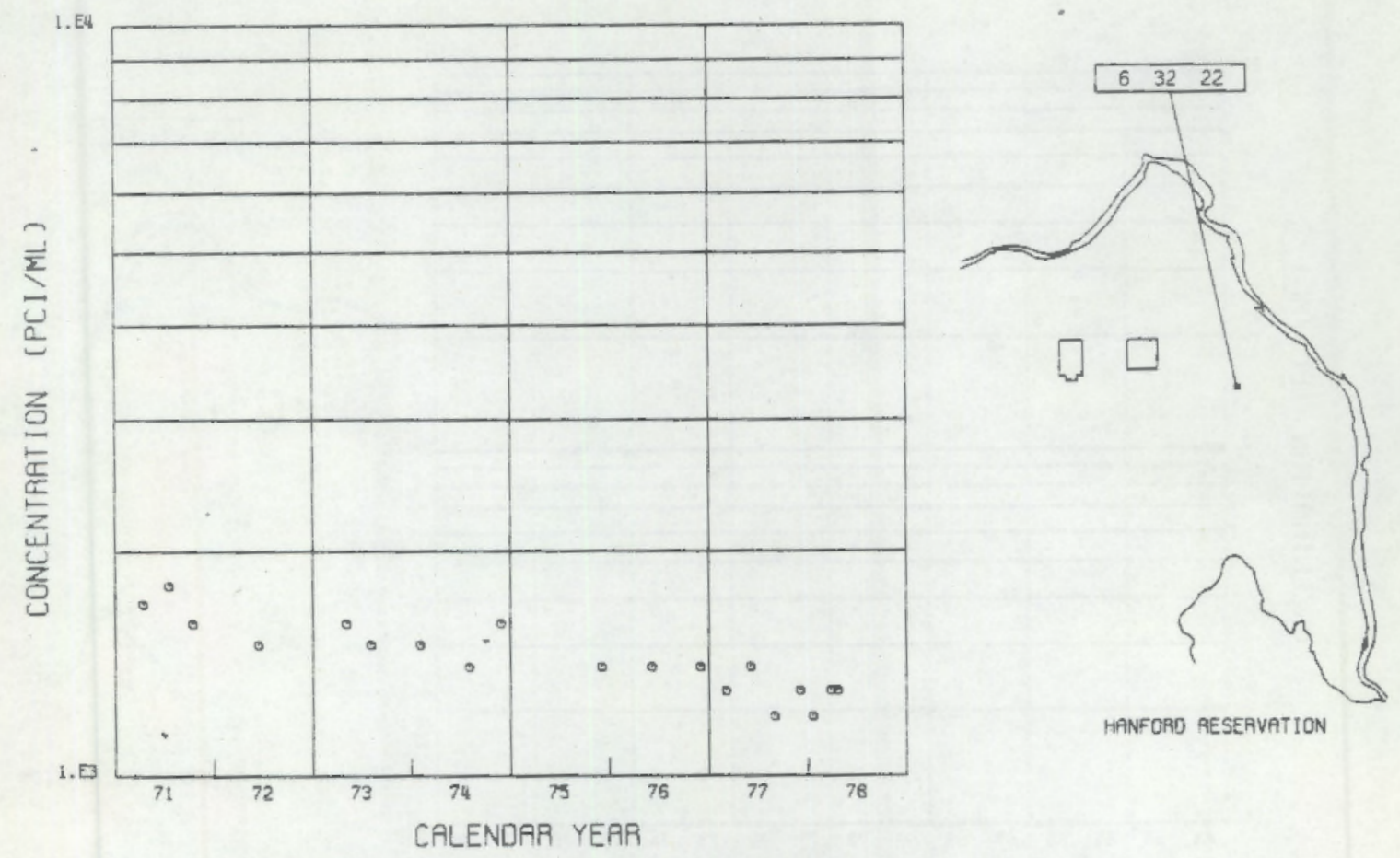

HANFORD RESEAVATION

FIGURE 8. Concentration History for Tritium in We11 6-32-22 

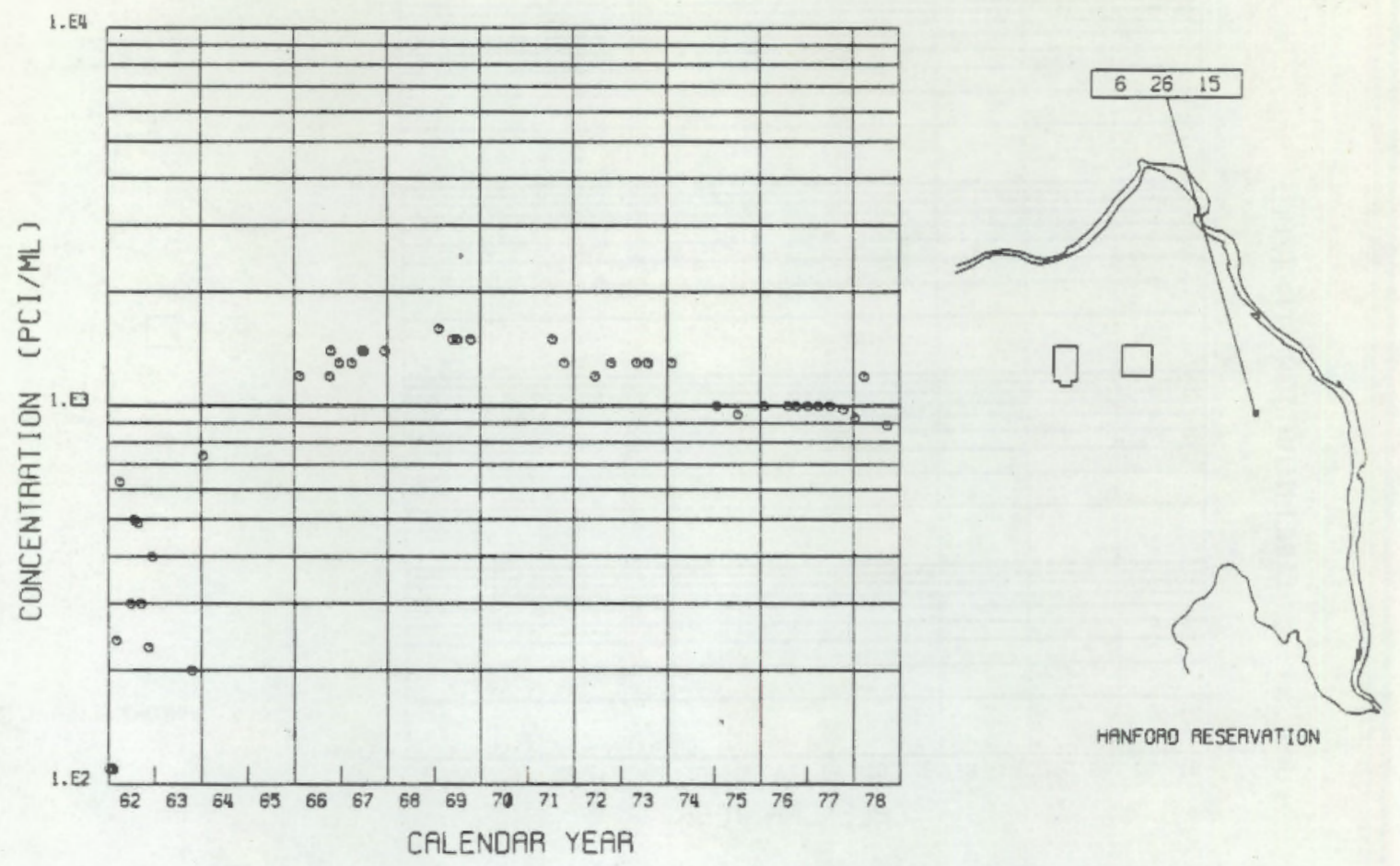

HANFORD RESEAVATION

FIGURE 9. Concentration History for Tritium in Wel1 6-26-15
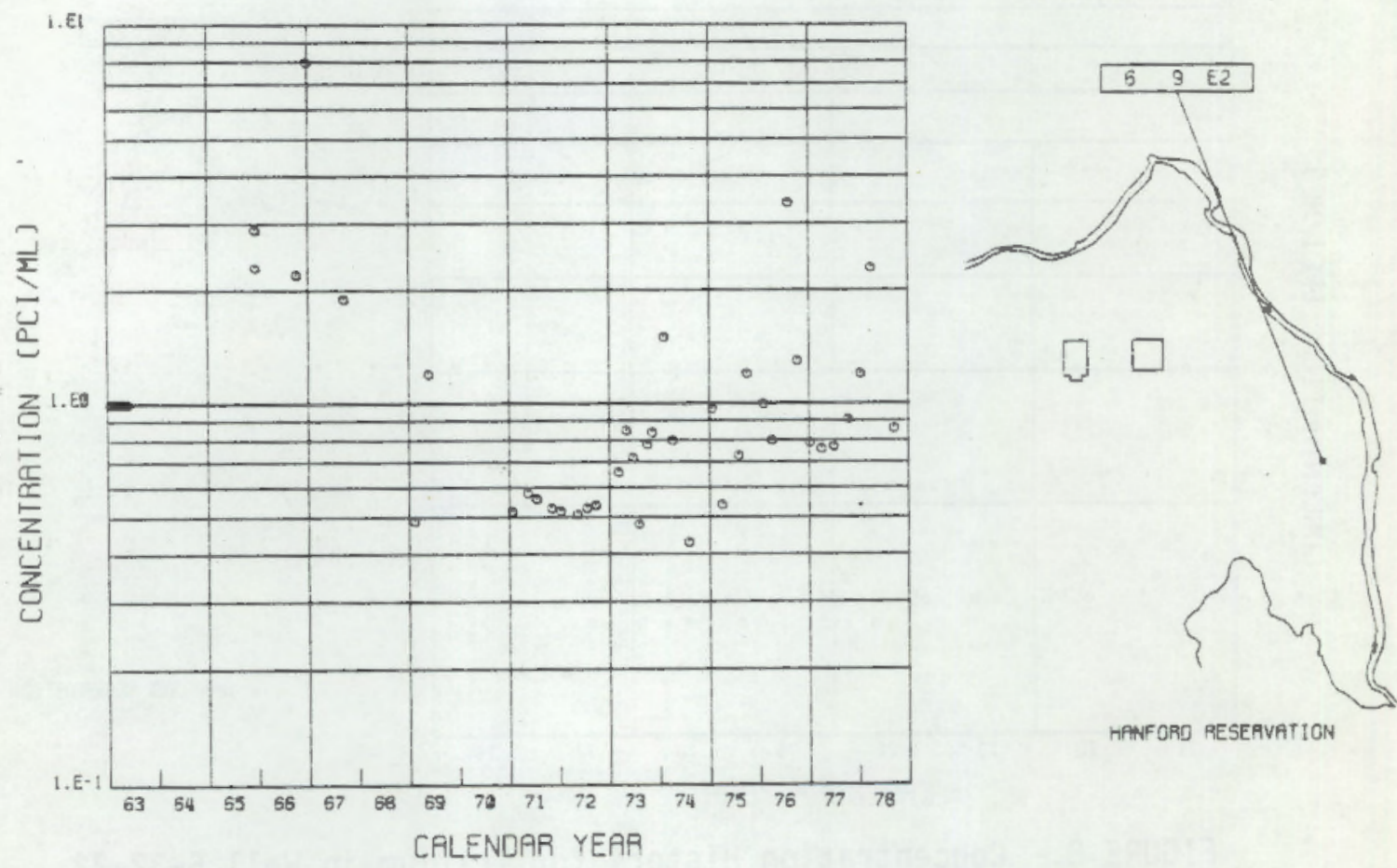

MANFORD RESERVATION

FIGURE 10. Concentration History for Tritium in Well 6-9-E2 

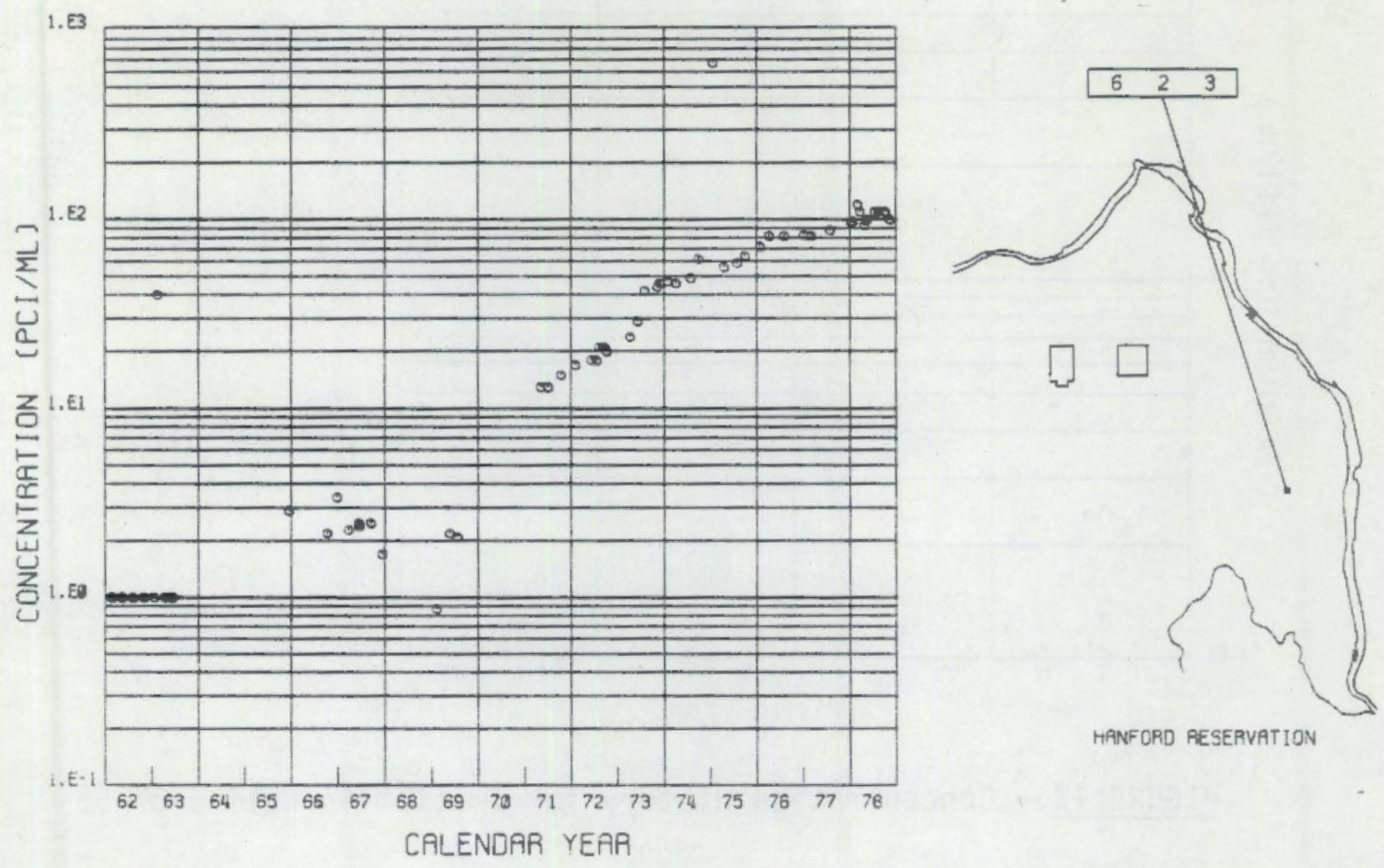

MANFORD RESERVATION

FIGURE 11. Concentration History for Tritium in Well 6-2-3

are used to monitor the southernmost lobe of ${ }^{3} \mathrm{H}$ plume. Well 6-2-3 also illustrates the arrival of the plume at the well's location, beginning in the mid-1960's.

The combination of operational effects and hydrological events can be seen in Figure 12, which shows a concentration history for well 6-87-55. This wel1 is located about 1 mile $(1.8 \mathrm{~km})$ from $N$ Reactor. The graph with its sinusoidal pattern illustrates a dynamic system which combines river flow, precipitation, reactor operations and geohydrology. 

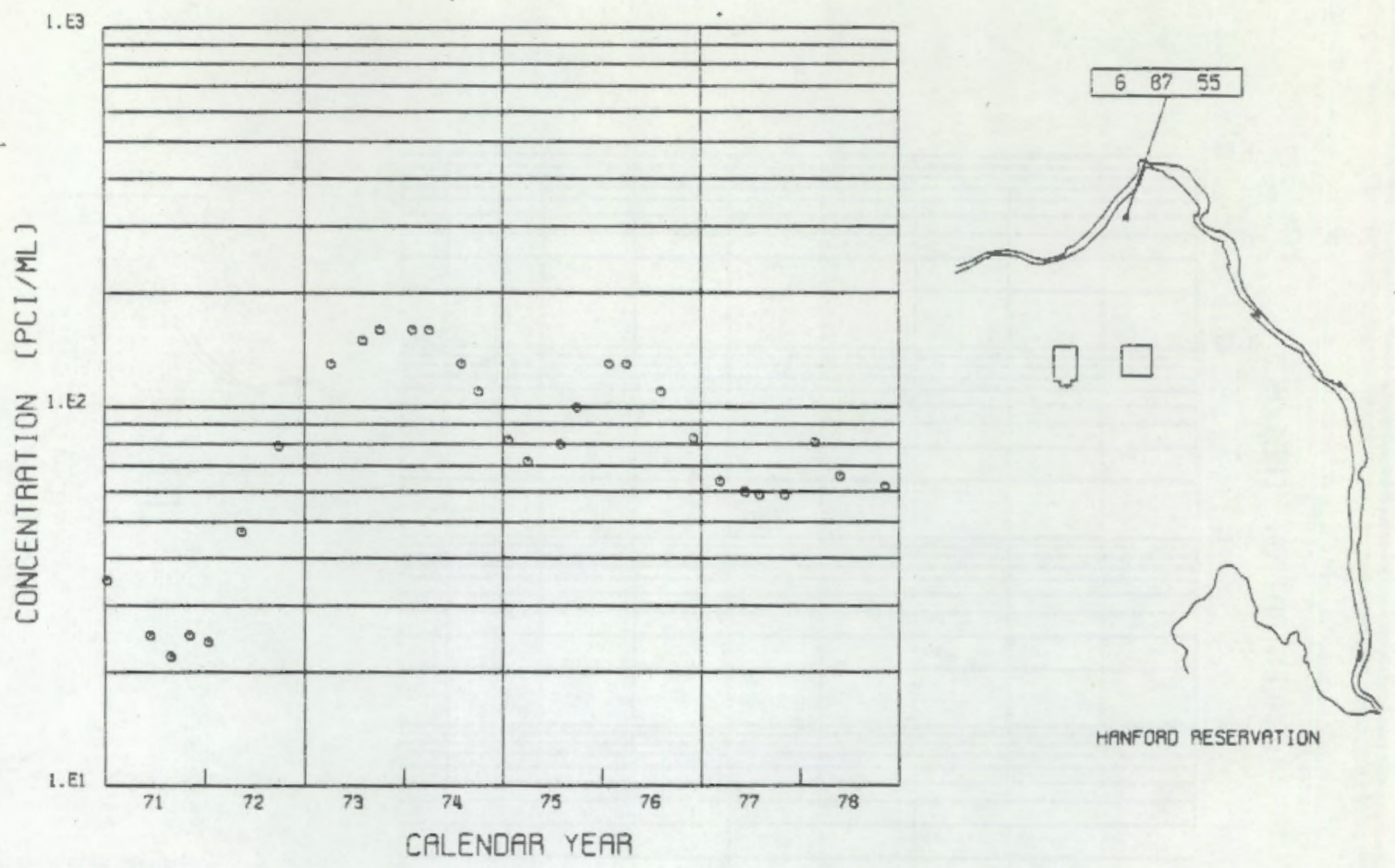

HFNFORD RESERVATION

FIGURE 12. Concentration History for Tritium in Well 6-87-55

NITRATE $\left(\right.$ NO3 $\left.{ }^{-}\right)$CONCENTRATION IN THE UNCONFINED GROUND WATER

Figure 13 shows the concentration and distribution of $\mathrm{NO}_{3}{ }^{-}$in the ground water at Hanford. Appendix A contains data on the maximum, minimum and average concentrations. Data collected in 1978 indicate 1 ittle aerial change in the nitrate plume. Zones of elevated nitrate concentration persist in the vicinity of the 200-E, 200-W, 100-D, 100-F, 100-H, 100-K, and 100-N Areas, and in the central portion of the main plume.

The concentration histories for Wel1s $1-\mathrm{H3}-1$ and 1-H4-3 (Figures 14 and 15) show marked increases in the level of $\mathrm{NO}_{3}{ }^{-}$concentration. Well 1-H4-3 was drilled specifically to monitor a solar evaporation facility used by United Nuclear Industries (UNI). The facility consists of a concrete structure previously used as a retention basin for the 100-H Reactor. The pond is currently used as a concentrator for wastes generated by UNI fuel fabrication activities in the 300 Area. Wastes placed in the basin normally contain copper, sodium, nitrate, and sulphate, with small amounts of other constituents such as chromium. The wastes do not contain radioactive materials other than 


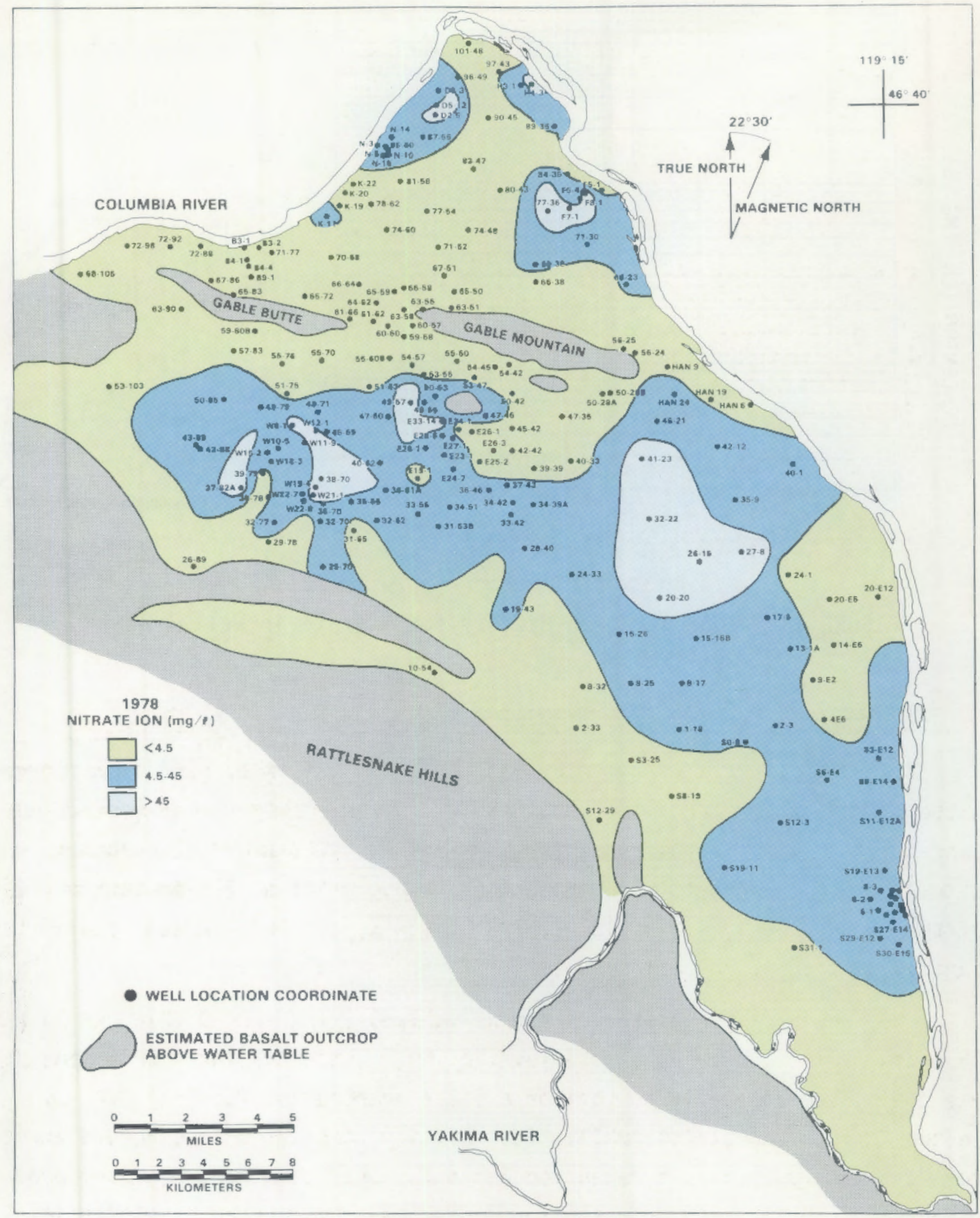

FIGURE 13. Nitrate Ion Distribution in Unconfined Ground Water 

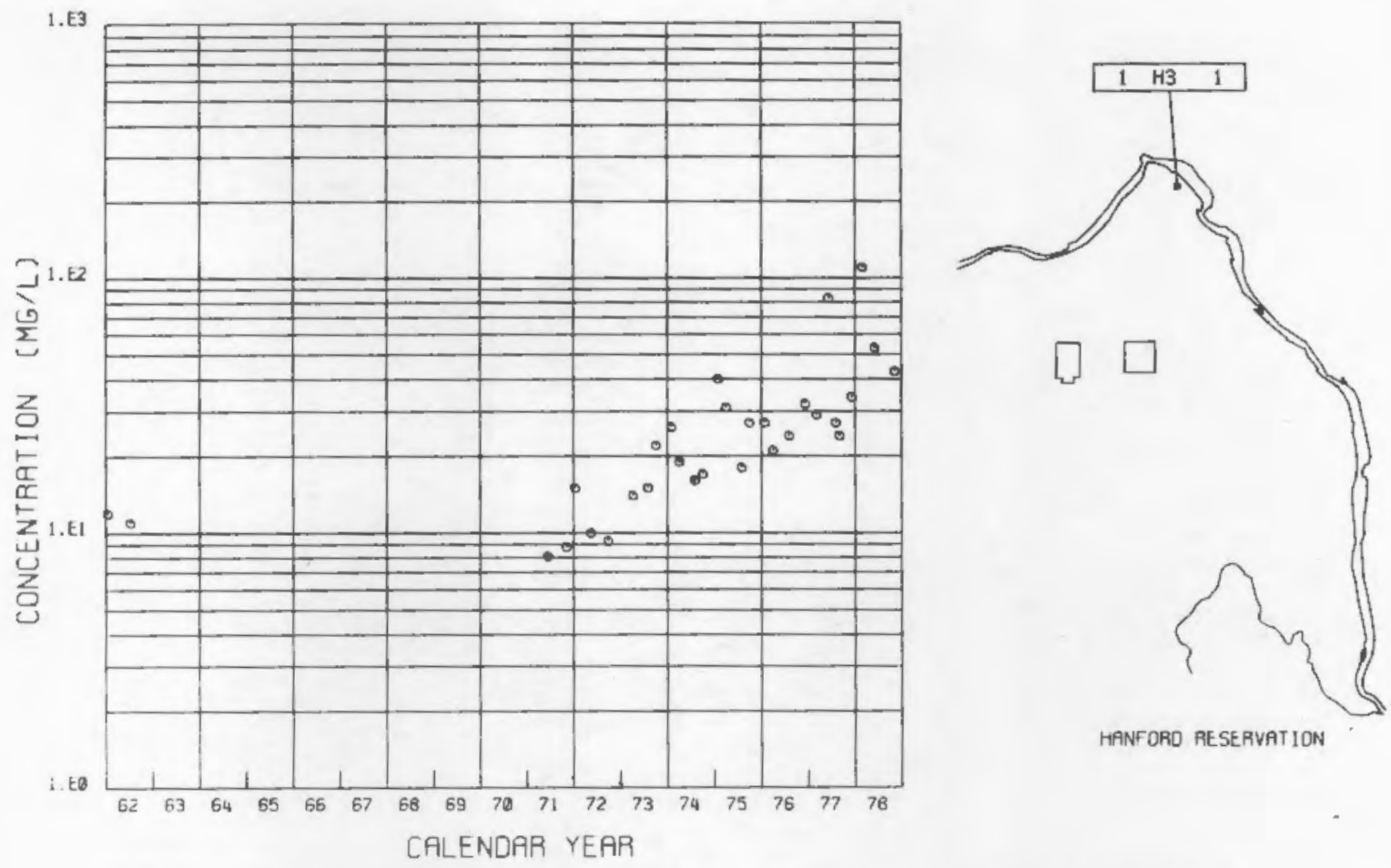

HANFORD RESERVATION

FIGURE 14. Concentration History for Nitrate in We11 1-H3-1
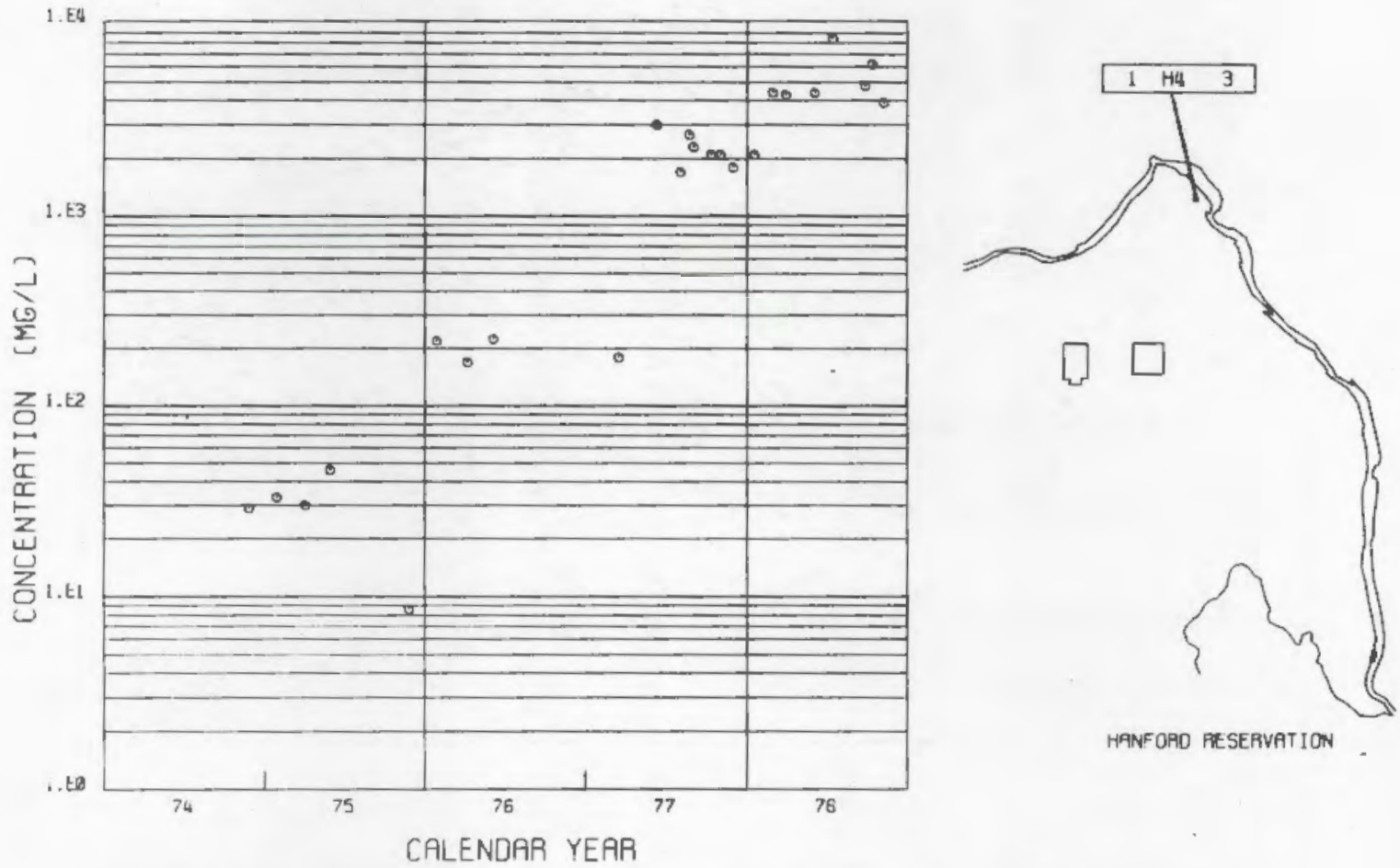

HANFORD FESERVATION

FIGURE 15. Concentration History for Nitrate in Well 1-H4-3 
trace amounts of uranium. The concentrated wastes eventually precipitate out of solution and form a recoverable crystalline coating on the bottom. An unknown quantity of this brine leaked from the pond through a joint or other fracture in the concrete basin and reached the ground-water table eventually. Mobilization of the brine was enhanced by water from a leaking valve in a fresh-water line servicing the facility. Upon realization of the problem, corrective action was initiated by UNI.

A decrease of nitrate concentration continues in We11 6-34-42 (Figure 16), where a cyclical pattern has developed. This pattern is the operational history of the 200-E Area. The very definite trend of increasing nitrate concentration observed in We11 6-17-5 (Figure 17), located north of the Washington Public Power Supply System projects, has reversed and decreasing concentrations of nitrate are now being observed. Maintenance work on this well and the installation of a sampling pump have eliminated much of the data scatter. The graph indicates the previous rapid increase in nitrate
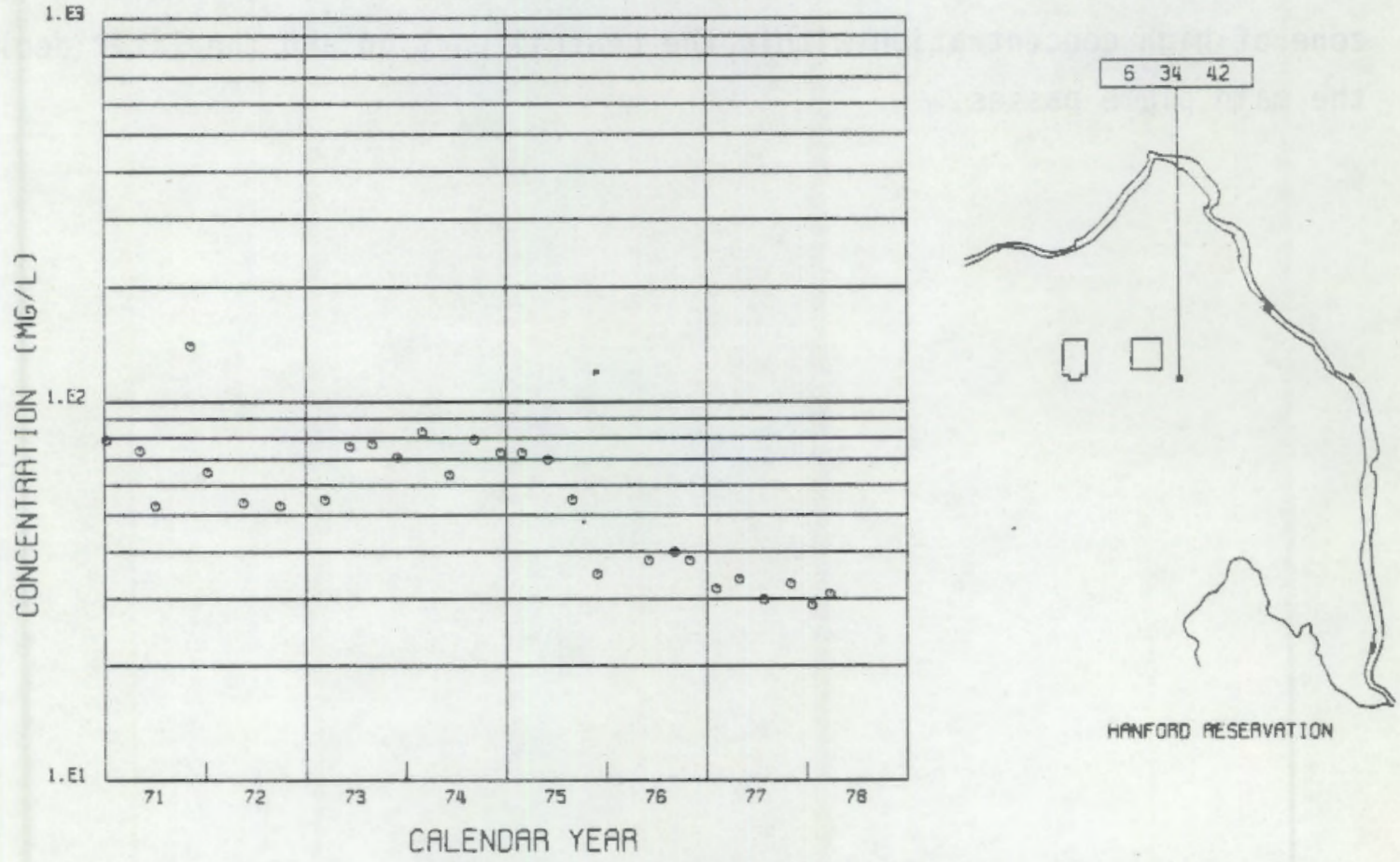

HANFORD RESERVATION

FIGURE 16. Concentration History for Nitrate in Well 6-34-42 

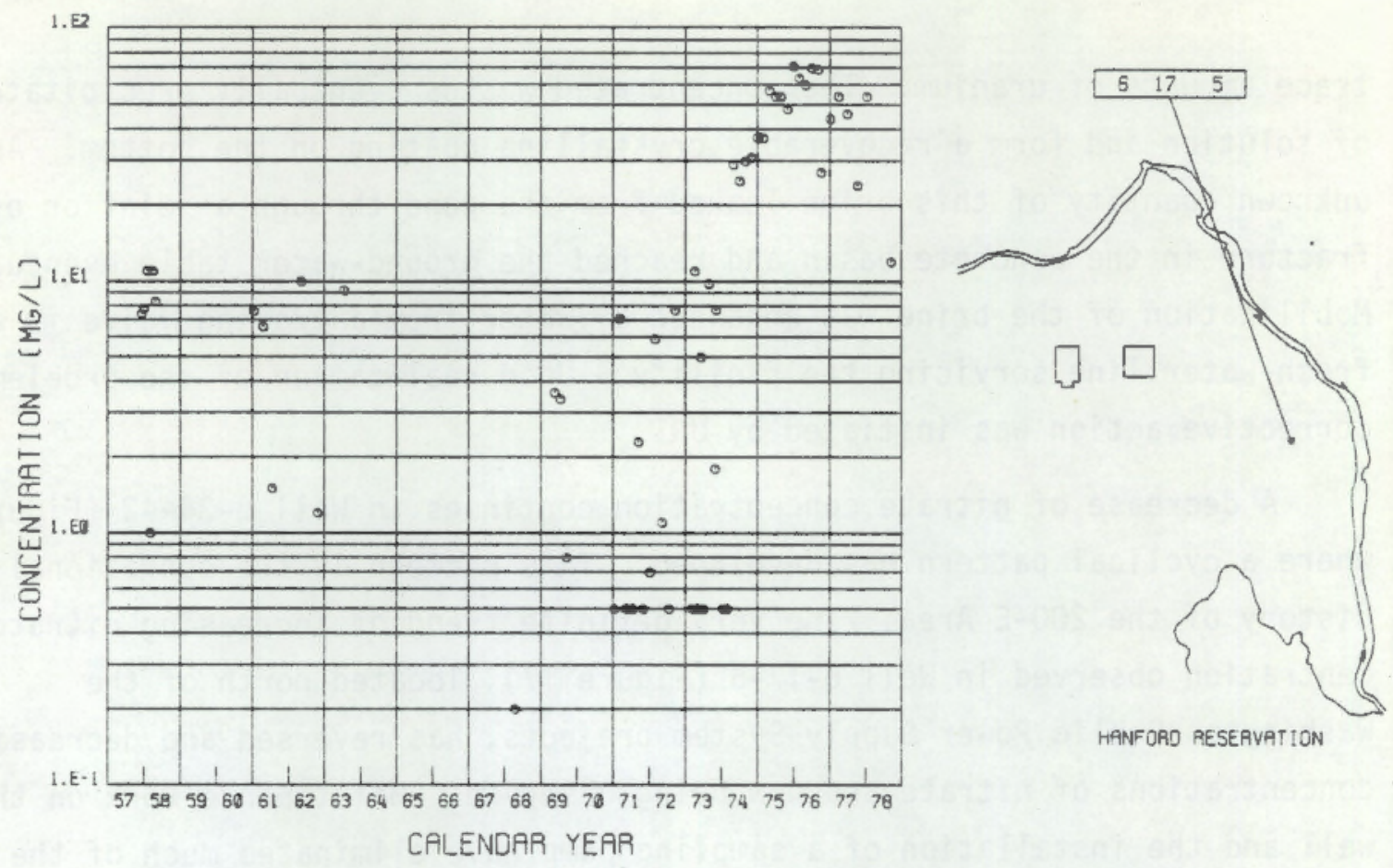

HANFORD RESERVATION

\section{FIGURE 17. Concentration History for Nitrate in Well 16-17-5}

concentration at this site, indicative of the movement or expansion of the zone of high concentration within the central portion and the later decline as the main plume passes. 


\section{ADDITIONAL CONTAMINANTS IN THE GROUND WATER}

Appendix $B$ contains data from the routine analysis of materials other than the primary tracers. These materials include uranium, gross alpha emitters, and fluoride ion, all found primarily in the fuel fabrications area (300 Area). A special analysis was performed for iodine-129 (see next section). In addition, water samples from the first aquifer were analyzed and the temperature distribution of water in the unconfined third aquifer was mapped.

\section{SPECIAL ANALYSES FOR IODINE-129}

During 1978, samples were collected from ten wells for iodine-129 analysis. Selection of these wells was based on location, with preference given to those, away from a source of contamination, so that the degree and direction of movement of this radionuclide could be ascertained. Existing data were complemented by the additional information.

Analyses were performed using neutron activation techniques (ASTM 1978). This analytical technique allows a detection level of approximately $1 \times 10^{-5}$ pico curies per liter $\left(1.7 \times 10^{-5} \%\right.$ of the Concentration Guides). Table 4 shows the results of the analyses for 1976, 1977 and 1978. Figure 18 shows the locations of the sampling points.

TABLE 4. ${ }^{129}$ I, ${ }^{60} \mathrm{Co}$, and ${ }^{106} \mathrm{Ru}$ Concentrations

\begin{tabular}{|c|c|c|c|}
\hline \multirow[b]{2}{*}{ Well No. } & \multicolumn{3}{|c|}{ Concentration, $\mathrm{pCi} / 2$} \\
\hline & 7291 & $50 \mathrm{Co}$ & T06Ru \\
\hline $699-8-17$ & 0.12 & 12.0 & 0.4 \\
\hline $699-15-26$ & 0.52 & 11.0 & 0.37 \\
\hline $699-20-20$ & 2.8 & 27.0 & 0.52 \\
\hline $699-32-72$ & $1.6 \times 10^{-3}$ & $4.6 \times 10^{-3}$ & $1.9 \times 10^{-3}$ \\
\hline $699-34-51$ & $1.8 \times 10^{-5}$ & $6.6 \times 10^{-4}$ & 0.00 \\
\hline $699-40-33$ & $2.2 \times 10^{-5}$ & 0.00 & 0.00 \\
\hline $699-41-23$ & 3.0 & 14.0 & 0.86 \\
\hline $699-42-12$ & 0.49 & 15.0 & 0.34 \\
\hline $699-45-42$ & 15.0 & $9.0 \times 10-5$ & $3.7 \times 10^{-3}$ \\
\hline $699-54-57$ & $1.6 \times 10^{-3}$ & $9.6 \times 10^{-5}$ & 0.00 \\
\hline
\end{tabular}




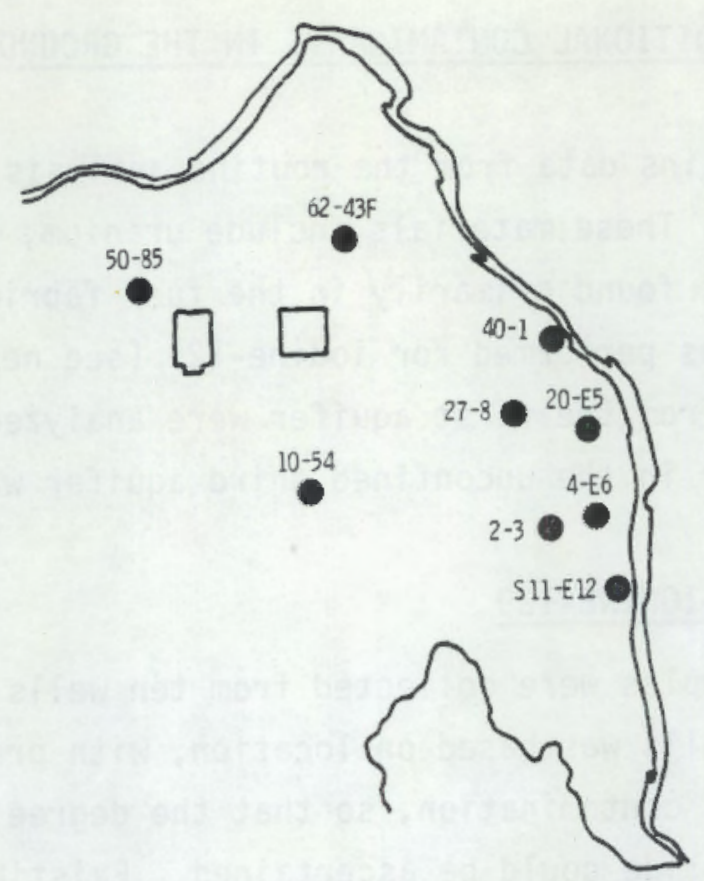

FIGURE 18. Location of Sample Points for I-129 Analysis

Iodine-129 is of interest because of its long half life (10 $0^{7}$ years) and its mobility in the ground-water environment. Analyses made during 1975-1978 verify that ${ }^{129}$ I follows the flow paths of the other major contaminants and its levels of concentration are reduced by diffusion and dispersion within the ground-water flow system. Past studies have shown that the majority of the 129 I is contained in the upper portions of the aquifer (Eddy et al. 1978). During 1978, no increase in ${ }^{129}$ I concentrations attributable to ground-water transport was observed in Columbia River water. Iodine-129 concentrations attributable to worldwide fallout were determined to be about $5 \times 10^{-4} \mathrm{pCi} / 2$ in the Columbia River (Houston and BTumer 1978).

\section{THERMAL CONTAMINATION}

Thermal features of aquifers are unique since warmer water tends to flow more rapidly than cooler water, displaying an apparent higher hydraulic conductivity.

Figure 19 shows the distribution of ground-water temperatures measured in January, 1979. The temperature ranges shown are the result of: 1) the natura? 


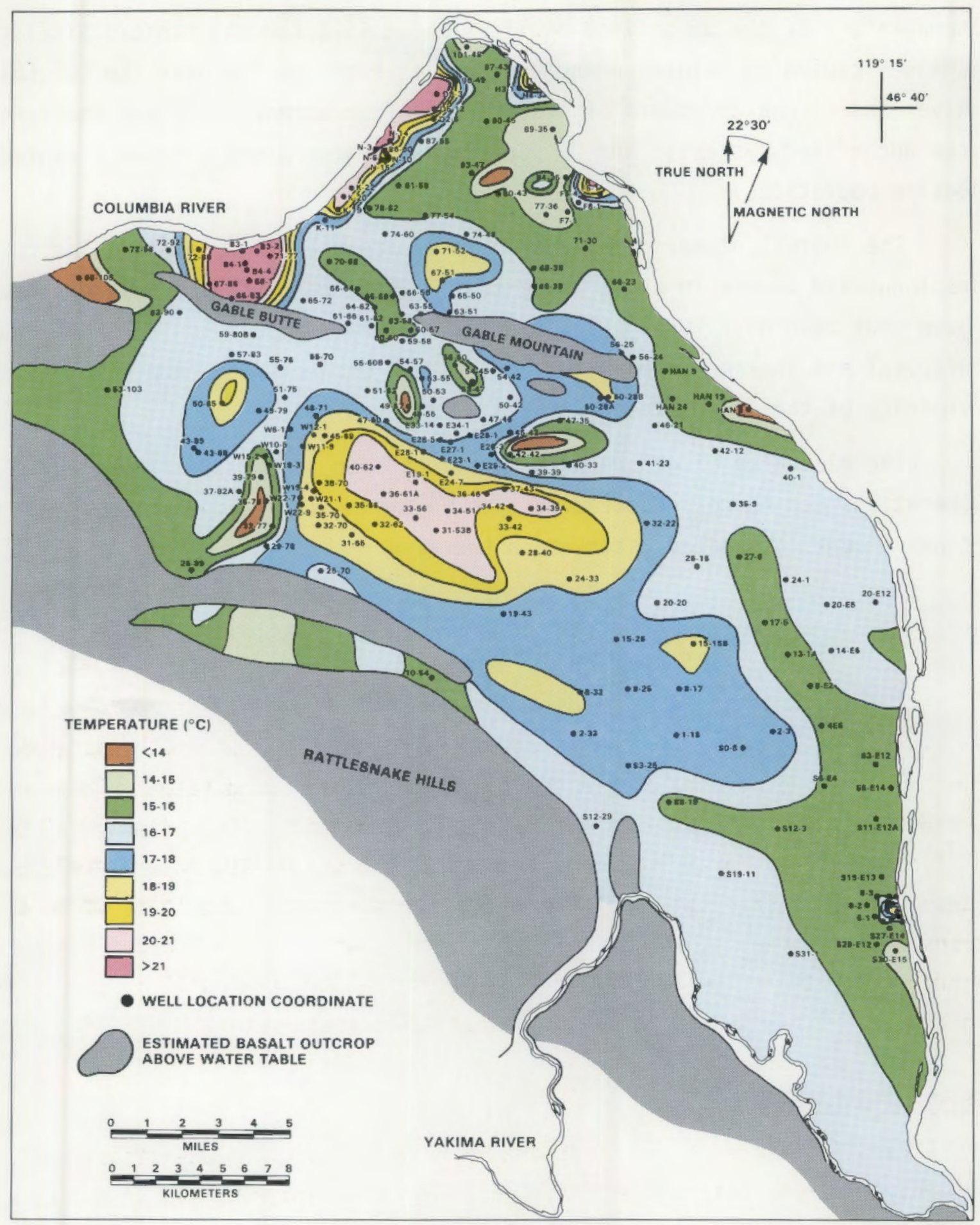

FIGURE 19. Distribution of Ground-Water Temperature Measured in January 1979 
temperature of the unconfined aquifer (about $15^{\circ} \mathrm{C}$ for the Hanford Site); 2) changes caused by natural phenomena such as bank storage near the Columbia River and discharge upward of ground water from warmer, confined aquifers into the unconfined systems; and 3) superimposed temperature gradients caused by onsite operations.

The thermal plumes attributable to onsite operations are similar to the radionuclide plumes in shape and extent. The areas in which reactors have been shut down have large quantities of hot water resulting from both ground disposal and leakage from retention basins. Ground-water temperatures in the vicinity of the $100-\mathrm{B}$ exceed $33^{\circ} \mathrm{C}$.

The discharge of ground-water that has been thermally affected by plant operations has no noticeable effect on Columbia River temperatures since only minor amounts of heated water reach the river. 


\section{RADIOLOGICAL IMPACT}

Ground-water transport of contaminants on the Hanford Site represents a potential pathway for exposure to radiation via water obtained from either 1) wells that tap the unconfined aquifer, or 2) the Columbia River, into which the unconfined aquifer discharges. The following discussion examines these potential pathways.

\section{GROUND WATER}

During 1978, drinking water on the Hanford Site was obtained from the unconfined aquifer at the Arid Lands Ecology (ALE) facility and the Fast Flux Test Facility (FFTF). Only the drinking water at ALE contains concentrations of radionuclides resulting solely from naturally-occurring radioactivity. The drinking water at FFTF contains elevated concentrations of ${ }^{3} \mathrm{H}$ from past waste disposal in the 200-East Area, as shown in Figure 6.

The impact on the total-body dose attributable to the ${ }^{3} \mathrm{H}$ in drinking water at FFTF (average $48,000 \mathrm{pCi} / \ell$ ) is estimated to be $0.6 \mathrm{mrem}$, based on an ingestion rate of 2201 iters/year at $40 \mathrm{hrs} /$ week. The 50 -year dose commitment from ${ }^{3} \mathrm{H}$ is the same as the annual dose because of the relatively short biological half life of this radionuclide.

The concentrations of ${ }^{3} \mathrm{H}$ in FFTF drinking water are low compared to the guidelines in MC-0524.

\section{COLUMBIA RIVER}

Ground-water entering the Columbia River from the Hanford Site is diluted by a factor of about 1000 because of the difference between the river and ground-water flow rates. During 1978, the average Columbia River flow rate reported by the U.S. Geological Survey (Houston and Blumer 1978) was 117,500 cfs $\left(3328 \mathrm{~m}^{3} / \mathrm{sec}\right)$. The flow rate from the unconfined aquifer (Myers 1978) was calculated to be about $100 \mathrm{cfs}\left(2.8 \mathrm{~m}^{3} \mathrm{sec}\right)$.

Tritium $\left({ }^{3} \mathrm{H}\right)$ may be observed at the farthest extreme boundaries of the contamination plume shown in Figure 6 ; this radionuclide would reach the river 
in the greatest concentrations at the earliest time. Figure 20 provides a comparison of identical analyses performed on samples taken upstream and downstream from the Hanford Site. The figure reveals no apparent significant difference between upstream and downstream concentrations of ${ }^{3} \mathrm{H}$. The columbia River transports approximately $42,000 \mathrm{Ci}$ of ${ }^{3} \mathrm{H}$ attributable to worldwide fallout (annual flow of $10^{14} \ell \times \sim 420 \mathrm{pCi} / \mathrm{l}$ ). Tritium discharges from $\mathrm{N}$ Reactor during 1978 contributed an additional $20.7 \%$ (330 pCi/l), (Greager 1979) but this contribution is not distinguishable from the variability resulting in fallout levels.

Looking at the distributions of other radionuclides shown in Figure 20, no difference between upstream and downstream concentrations is apparent except for those observed for ${ }^{60} \mathrm{Co}$. The ${ }^{60} \mathrm{Co}$ is attributable to routine past reactor operations (i.e., for 1978 , the $0.96 \mathrm{~m}^{3} \mathrm{sec}$ released into the Columbia River's average flow of $117,500 \mathrm{cfs}\left(3328 \mathrm{~m}^{3} / \mathrm{sec}\right)$ would resuit in an average annual concentration of $0.009 \mathrm{pCi} / \ell$ ). The other radionuclides shown in Figure 20 are from worldwide fallout $\left({ }^{90} \mathrm{Sr}\right.$ and $\left.{ }^{106} \mathrm{Ru}\right)$ and natural causes $\left({ }^{40} \mathrm{~K}\right.$ and $\left.U\right)$ (Greager 1979). 


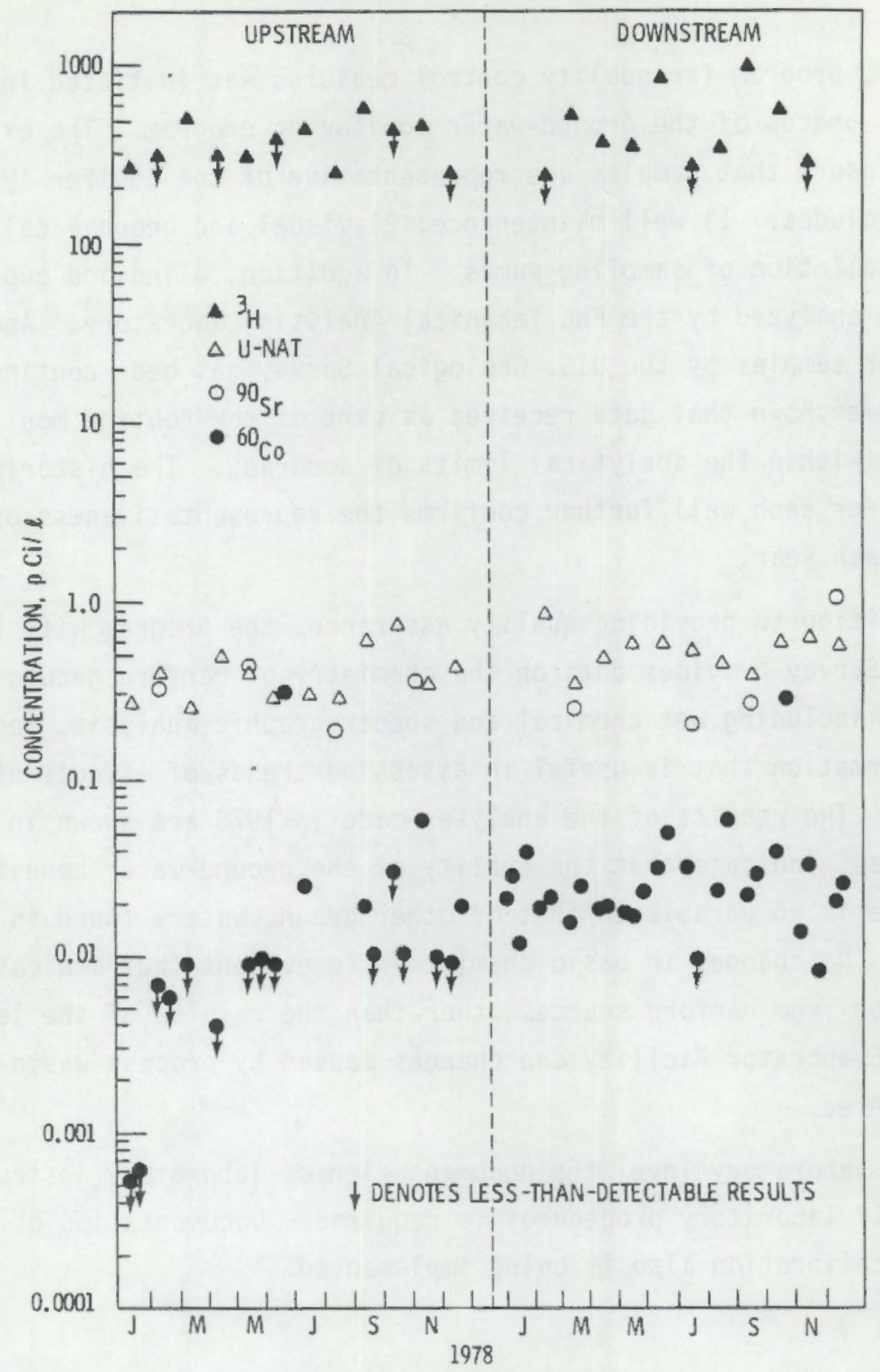

FIGURE 20. Upstream and Downstream Concentration of Radionuclides in Columbia River Water 


\section{QUALITY CONTROL}

The PNL program for quality control measures was initiated in 1974 and reaches all phases of the ground-water monitoring program. The extensive effort to insure that samples are representative of the aquifer system beneath the site includes: 1) well maintenance; 2) visual and geophysical inspection; and 3) installation of sampling pumps. In addition, blind and duplicate samples are analyzed by the PNL Technical Analysis Laboratory. Analysis of ground-water samples by the U.S. Geological Survey has been continued. These programs have shown that data received as part of the routine monitoring program are within the analytical limits of accuracy. The historical analytical record for each well further confirms the representativeness of the data collected each year.

In addition to providing quality assurance, the program with the U.S. Geological Survey provides data on the chemistry of Hanford ground-water. These data, including wet chemical and spectrographic analysis, represent background information that is useful in assessing trends of effects of plant operations. The results of the analyses made in 1978 are shown in Appendix $C$. These analyses indicate that the quality of the ground-water beneath the Hanford Site is comparable to that of other ground-waters found in eastern Washington. No changes in basic chemistry are evident that indicate chemical contamination from Hanford sources other than the results of the leak at the $183 \mathrm{H}$ Solar Evaporator Facility and changes caused by process waste disposal in the 300 Area.

At the laboratory level the documentation of laboratory instrument calibrations and all laboratory procedures is required. Documentation of field instrument calibration also is being implemented. 


\section{REFERENCES}

American Society for Testing and Materials (ASTM). 1978. 1978 Annual Book of ASTM Standards. Part 31: Water. American Society for Testing and Materials, 1916 Race St., Philadelphia, PA. 19103.

Code of Federal Regulations. Title 40, part 141. (Cited in text as 40 CFR 141.)

Greager, E. M. March 1979. United Nuclear Industries, Inc., Reactor and Fuels Production Facilities, 1978 Effluent Release Report. United Nuclear Industries, Richland, WA 99352.

Eddy, P. A., D. A. Myer and J. R. Raymond. August 1978. Vertical Contamination in the Unconfined Ground-Water at the Hanford Site, Washington. PNL2724, Pacific Northwest Laboratory, Richland, WA. 99352.

Houston, J. R. and P. J. Blumer. April 1978. Environmental Surveillance at Hanford for $\mathrm{CY}-1978$, PNL-2932. Pacific Northwest Laboratory, Richland, WA. 99352.

McGhan, V. L. and D. W. Damschen. June 1977. Hanford Wells. BNWL-2296, Pacific Northwest Laboratory. Richland, WA. 99352.

Myers, D. A. April 1978. Environmental Monitoring Report on the Status of Ground Water Beneath the Hanford Site January-December 1977. PNL-2624, Pacific Northwest Laboratory, Richland, WA. 99352.

Trescott, P. C., and G. F. Pinder. 1970. "Air Pump for Sma11-Diameter Piezometers," Ground Water, Vo1. 8, No. 3, May-June.

U.S. Department of Energy. March 1977. "Standards for Radiation Protection," Chapter 0524 (Appendix) Annex A, Table II, Column 2, U.S. Department of Energy, Washington, D. C. 

APPENDIX A

A-1 


\section{APPENDIX A}

Total Beta, Tritium, Nitrate Concentrations in the Ground-Water (unconfined aquifer), Taken March 22, 1979 at $6: 26: 32$

(PNL We11s)(Calendar Year 1978)

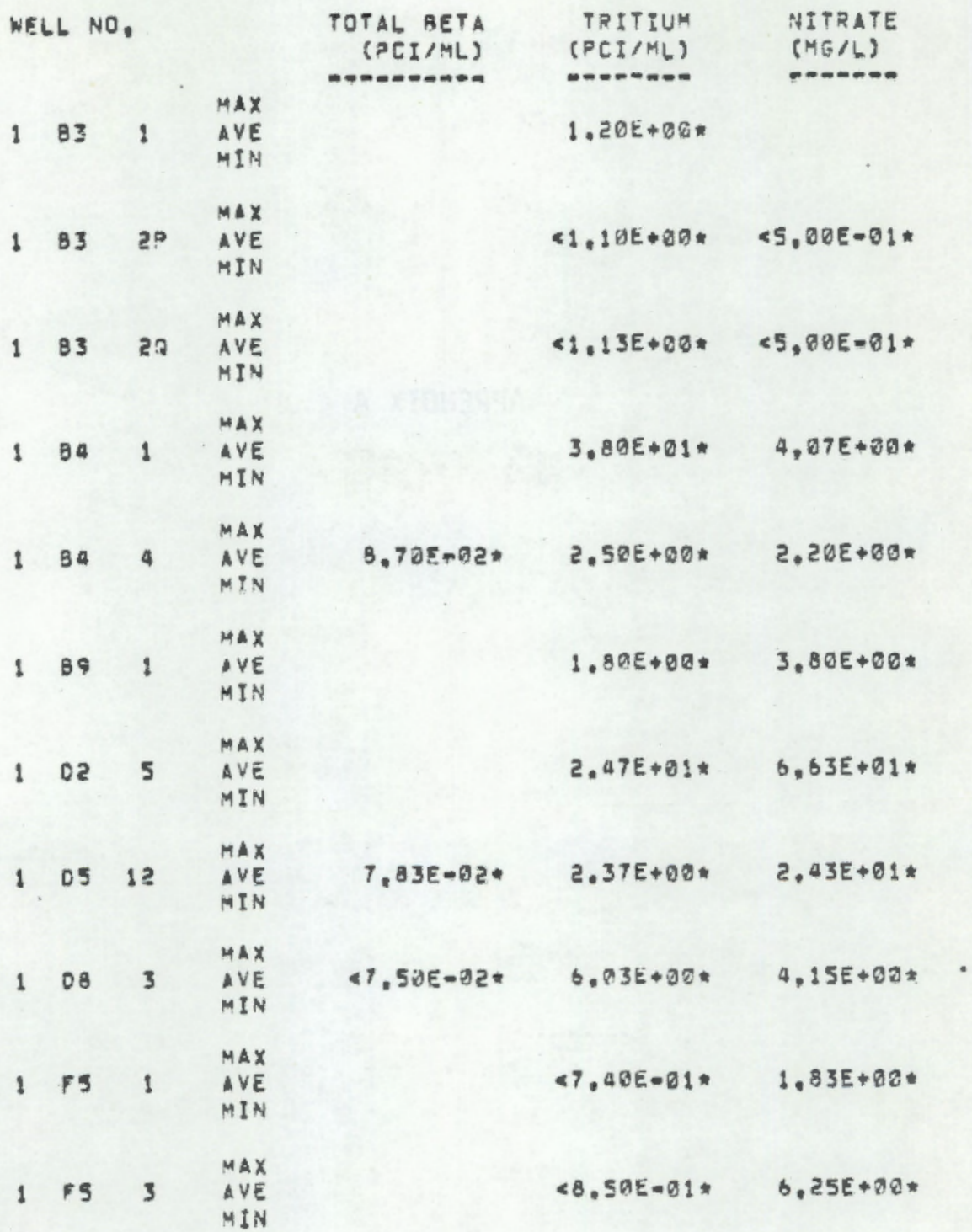




\begin{tabular}{|c|c|c|c|c|c|c|}
\hline \multicolumn{4}{|c|}{ WELL NO, } & \multirow{2}{*}{$\begin{array}{r}\text { TOTAL AETA } \\
\text { (FCI/ALJ) } \\
\text { OOA }\end{array}$} & \multirow{2}{*}{$\begin{array}{l}\text { IRITIUM } \\
\text { (PCIIML) } \\
1.08 E+07 \text { * }\end{array}$} & \multirow{2}{*}{$\begin{array}{c}\text { NITRATE } \\
\text { (MG/L) } \\
-0-00- \\
\text { Z,ZZE+30 }\end{array}$} \\
\hline 1 & $F 5$ & 4 & $\begin{array}{l}\text { MAX } \\
\text { IVE } \\
\text { MIN }\end{array}$ & & & \\
\hline 1 & $F 5$ & $b$ & $\begin{array}{l}\text { MAX } \\
A \cup E \\
M ! N\end{array}$ & & $<7.40 E=05 \%$ & $<5,00 E-01$ \\
\hline 1 & $F 7$ & 1 & $\begin{array}{l}H A X \\
A \cup E \\
M ? N\end{array}$ & & $1.01 E+80 \circ$ & $5,77 E+01$ \\
\hline 1 & 53 & 1 & $\begin{array}{l}\text { HAX } \\
\text { AVE } \\
\text { HIV }\end{array}$ & & $2,53 t+01 *$ & $7,57 E+2: *$ \\
\hline 1 & 58 & 2 & $\begin{array}{l}\text { MAX } \\
\text { AVE } \\
\text { MIV }\end{array}$ & & $1.10 E+01 *$ & $3.73 E+0$. \\
\hline 1 & 143 & 1 & $\begin{array}{l}\text { MAX } \\
\text { AVE } \\
\text { MIN }\end{array}$ & & $1.10 E+91=$ & $6.87 E+61 *$ \\
\hline 1 & 14 & 3 & $\begin{array}{l}\text { MAX } \\
\text { AVE } \\
\text { MIN }\end{array}$ & $\begin{array}{l}1.5 \forall E+00 \\
7.63 E-01 \\
5.96 E-9 !\end{array}$ & $\begin{array}{l}6.70 E+00 \\
5.65 E+209 \\
4.80 E+200\end{array}$ & $\begin{array}{l}8,40 E+83 \\
4,81 E+03 \\
2,12 E+93\end{array}$ \\
\hline 1 & $x$ & 11 & $\begin{array}{l}M A X \\
A V E \\
M I N\end{array}$ & & $\Delta, 2 \leq \varepsilon+01 *$ & $6.33 E+00$. \\
\hline 1 & k & 19 & $\begin{array}{l}\text { MAX } \\
\text { AYE } \\
\text { MIN }\end{array}$ & & $4.75 E+00$ & $2.93 E+00 *$ \\
\hline 1 & $k$ & 27 & $\begin{array}{l}\operatorname{MAX} \\
\text { MVE } \\
\text { MIN }\end{array}$ & & $2.10 E+00 *$ & $1,05 E+020$ \\
\hline$\$$ & K & 22 & $\begin{array}{l}\text { MAX } \\
\text { AVE } \\
H I N\end{array}$ & . & $3.77 E+001$ & $3.00 E-x I *$ \\
\hline 1 & $\mathbf{N}$ & 3 & $\begin{array}{l}\text { MAX } \\
\text { AVE } \\
\text { MIN }\end{array}$ & $7,775=9: 9$ & $5,385+01$ & \\
\hline 1 & $N$ & 4 & $\begin{array}{l}\text { MAX } \\
\text { MVE } \\
\text { MIN }\end{array}$ & $1.22 E-01$. & $5.47 E+D: 1$ & $4,20 E+00$ \\
\hline 1 & Hi & 6 & $\begin{array}{l}\text { MAX } \\
\text { AVE } \\
\text { MIN }\end{array}$ & $3,57 E-0 ! *$ & $5,67 E+Q 1$ & \\
\hline 1 & iv & 14 & $\begin{array}{l}\text { YAX } \\
\text { AVE } \\
\text { MIV }\end{array}$ & $5,50 \varepsilon-0: \%$ & $5.33 E+01 *$ & $1.20 E+01 *$ \\
\hline ! & $N$ & 15 & $\begin{array}{l}M \leq X \\
A V E \\
M I V\end{array}$ & $2,23 E-01$ & $5.53 E+01 *$ & $1,095+0:$ \\
\hline
\end{tabular}


WetL NO.

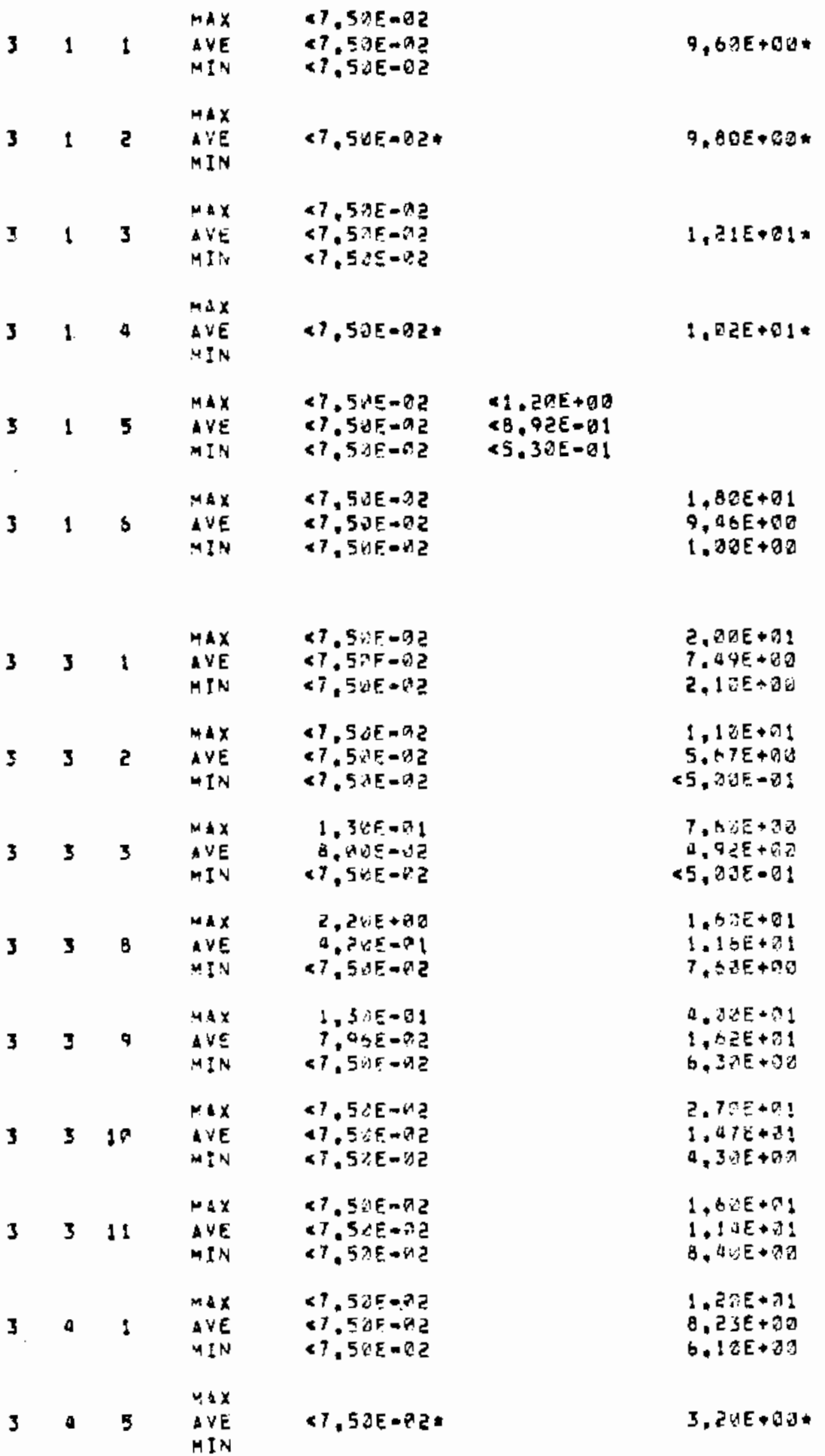

NITAATE

(PCI/NL) (MG/L)

(PCI/ML)

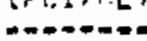

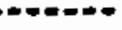

$1,82 E+01$

$9.46 E+00$ 


\begin{tabular}{|c|c|c|c|c|c|c|}
\hline WEL & $=N O$. & & & $\begin{array}{l}\text { TOTAL BETA } \\
\text { (PCI IML) }\end{array}$ & $\begin{array}{l}\text { TR!TILM } \\
\text { [PEITML] } \\
M=0-0=0\end{array}$ & $\begin{array}{l}\text { NITRATE } \\
\text { (MGLL) } \\
\text { Mama-an }\end{array}$ \\
\hline 3 & a & 7 & $\begin{array}{l}\operatorname{MAX} \\
\operatorname{LVE} \\
\text { MIN }\end{array}$ & $\begin{array}{l}67,50 E-9.2 \\
<7,50 E-02 \\
17,50 E-02\end{array}$ & & $\begin{array}{l}1,50 E+01 \\
1,16 E+01 \\
0.70 E-00\end{array}$ \\
\hline 3 & 4 & 9 & $\begin{array}{l}M A X \\
M V E \\
M I N\end{array}$ & $\begin{array}{l}\times 7.59 E-02 \\
77,57 E-\Delta 2 \\
\times 7.5 \Delta E-02\end{array}$ & & $\begin{array}{l}1.70 E+Q 1 \\
1.12 E+71 \\
3.30 E+0 Q\end{array}$ \\
\hline 3 & 4 & .0 & $\begin{array}{l}\text { MAX } \\
\text { MVE } \\
\text { MIN }\end{array}$ & $\begin{array}{l}<7.5 \partial E-82 \\
47.54 E-82 \\
<7.56 E-02\end{array}$ & & $\begin{array}{l}1,67 E+0 ! \\
1,27 E+91 \\
9,60 E+09\end{array}$ \\
\hline 3 & 5 & $\mathbf{i}$ & $\begin{array}{l}\text { MAX } \\
\text { IVE } \\
\text { MIN }\end{array}$ & $47.50 E=82 t$ & & $1.37 \varepsilon+01 \%$ \\
\hline 3 & $b$ & 1 & $\begin{array}{l}\text { MAX } \\
\text { AVE } \\
\text { MIN }\end{array}$ & $.7 .50 E=024$ & & $1,27 E+01 *$ \\
\hline 3 & 8 & 1 & $\begin{array}{l}\text { MAX } \\
\text { MVE } \\
M I N\end{array}$ & $-1.5 \partial E-02 \%$ & & $3,73 E+60 *$ \\
\hline 3 & 8 & 2 & $\begin{array}{l}M A X \\
A \cup E \\
M I N\end{array}$ & $4.50 E-02 t$ & & $8,77 E+90 *$ \\
\hline 3 & 8 & $\mathbf{3}$ & $\begin{array}{l}\text { MAL } \\
\text { AVE } \\
\text { MIN }\end{array}$ & $4.500-02$. & & $2,73 E+09 \neq$ \\
\hline 6 & 331 & 10 & $\begin{array}{l}\text { MAX } \\
\text { AVE } \\
\text { MIN }\end{array}$ & & $<1,11 \varepsilon+00 *$ & $6,67 E-D i *$ \\
\hline b & & & $\begin{array}{l}\text { MAX } \\
\text { AVE } \\
M I N\end{array}$ & & & $9,13 E+00 *$ \\
\hline b & 529 & $E: 2$ & $\begin{array}{l}N A X \\
A \cup E \\
M I N\end{array}$ & & & $1,30 \varepsilon+E 1 *$ \\
\hline$b$ & SET & $E: a$ & $\begin{array}{l}\text { MAX } \\
\text { AVE } \\
\text { MIN }\end{array}$ & $47.50 E-02$. & & $\begin{array}{l}1,48 E+31 \\
1.25 E+01 \\
8,92 E+03\end{array}$ \\
\hline b & 519 & $\varepsilon \downarrow 3$ & $\begin{array}{l}\text { MAX } \\
\text { MVE } \\
\text { MIN }\end{array}$ & & & $9.83 \varepsilon+00 *$ \\
\hline 6 & 519 & 11 & $\begin{array}{l}\text { MAX } \\
\text { AYE } \\
M ! N\end{array}$ & & & $3.31 \varepsilon+\theta 1 *$ \\
\hline Dise & $\begin{array}{l}\text { NAME } \\
\text { S!A }\end{array}$ & $\begin{array}{l}6518 \\
20\end{array}$ & $\begin{array}{l}E Z A P \\
M A X \\
A V E \\
Y I N\end{array}$ & DOES NOT MATCH & INPUT NAME 6 & $\begin{array}{l}5: 8 E 2 B \\
5,20 E=3 !\end{array}$ \\
\hline
\end{tabular}


NELL NO.

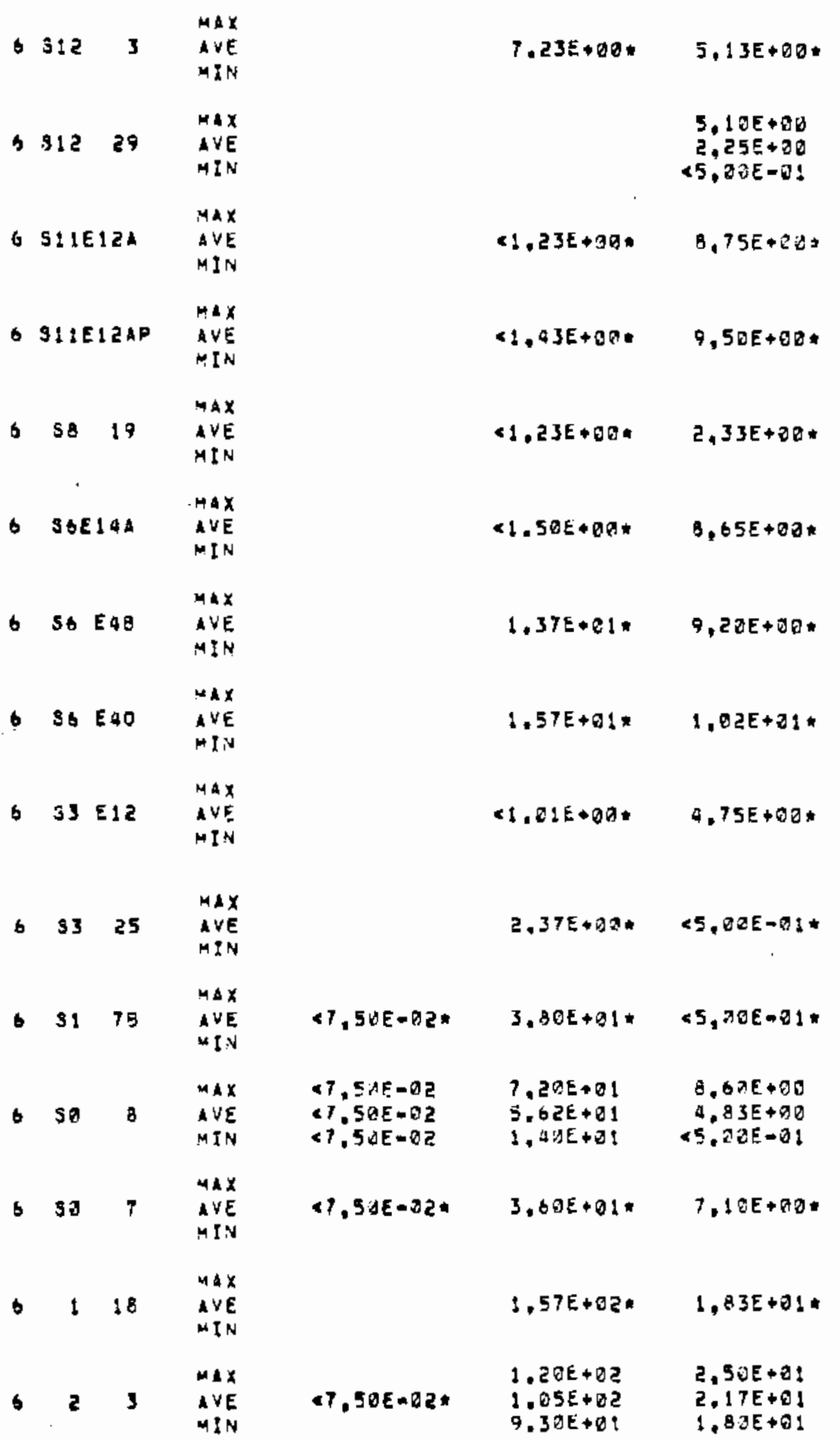

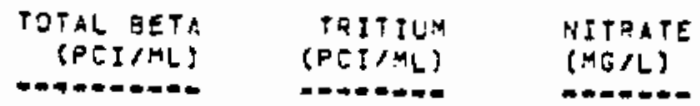

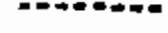


NELL NO.

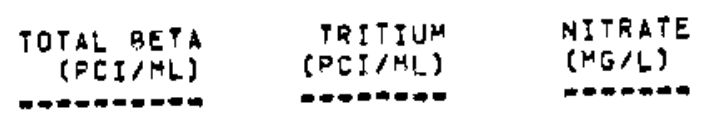

\begin{tabular}{|c|c|c|c|c|c|c|}
\hline 6 & 2 & $33 k$ & $\begin{array}{l}\text { MAX } \\
\text { AVE } \\
\text { MIN }\end{array}$ & & $0.55 E+60$ & $1,20 E+00 *$ \\
\hline 6 & 3 & 45 & $\begin{array}{l}\text { MAX } \\
\text { AYE } \\
\text { MIN }\end{array}$ & & $1,39 E+00$ & $\begin{array}{l}5,90 E+00 \\
3,0 B E+00 \\
8, \nabla \cup E-0 !\end{array}$ \\
\hline 6 & $a$ & E6 & $\begin{array}{l}\text { MAX } \\
\text { AVE } \\
M I N\end{array}$ & & $41,00 \varepsilon+00=$ & $a, 30 E+00 *$ \\
\hline$b$ & 8 & 17 & $\begin{array}{l}\text { HAX } \\
\text { AVE } \\
\text { MIN }\end{array}$ & $47,50 E=02 *$ & $1.97 E+02 \%$ & $1,94 E+81 *$ \\
\hline b & $\theta$ & 25 & $\begin{array}{l}M \triangle X \\
A V E \\
M I N\end{array}$ & $<7,5 Q E-02$. & $1.27 E+\square 2 *$ & $2.10 E+01 *$ \\
\hline 6 & 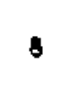 & 32 & $\begin{array}{l}\text { MAX } \\
\text { AVE } \\
\text { MIN }\end{array}$ & & $2.90 E+80 *$ & $7,53 E-0 ! *$ \\
\hline 6 & 9 & E2 & $\begin{array}{l}\text { MAX } \\
\text { MVE } \\
\text { YIN }\end{array}$ & & $1,05 E+90$ & $45,00 E-01 *$ \\
\hline b & 10 & E12 & $\begin{array}{l}M A X \\
\text { MVE } \\
\text { IIN }\end{array}$ & & $1.36 E+00 \omega$ & 1.07E*9!* \\
\hline 6 & 13 & 14 & $\begin{array}{l}\text { MAX } \\
\text { AVE } \\
\text { MIN }\end{array}$ & $47.50 E-82 \pi$ & $\begin{array}{l}6,80 E+\theta 2 \\
3.01 E+02 \\
1.20 E+21\end{array}$ & $\begin{array}{r}1,0 D E+D ! \\
6,75 E+\partial \theta \\
<5,00 E-0 !\end{array}$ \\
\hline 3 & 23 & 18 & $\begin{array}{l}\text { MAX } \\
\text { AVE } \\
\text { MIN }\end{array}$ & & $2.67 E+02 *$ & $7.07 E+20 *$ \\
\hline 6 & 10 & EbP & $\begin{array}{l}\text { MAX } \\
\text { AVE } \\
M ! N\end{array}$ & & $<1,20 E+O B *$ & $<5,20 E-91=$ \\
\hline 6 & 34 & 560 & $\begin{array}{l}\text { MAX } \\
\text { AVE } \\
\text { MIN }\end{array}$ & & $<1,23 E+09$ & $<5,8 g E-7 i *$ \\
\hline s & 14 & E68 & $\begin{array}{l}M A X \\
\text { AVE } \\
\text { MIN }\end{array}$ & & $<1,26 E+00 *$ & $<5,00 E-01 *$ \\
\hline b & da & $E \in S$ & $\begin{array}{l}\text { MAX } \\
\text { AVE } \\
\text { MIN }\end{array}$ & & $<1.37 E+00 *$ & $<5.025-91 *$ \\
\hline 6 & 10 & EGT & $\begin{array}{l}\text { MAX } \\
\text { AVE } \\
\text { MIN }\end{array}$ & & $1.04 E+01 *$ & $5,25 E+80$ \\
\hline
\end{tabular}


WEL $\mathrm{NO}$

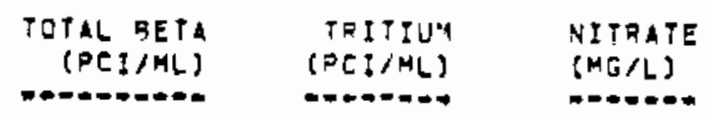

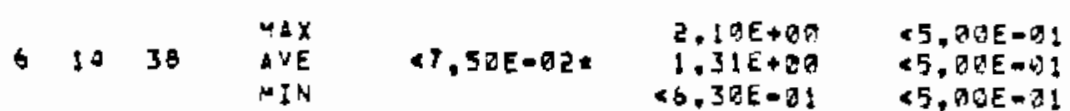

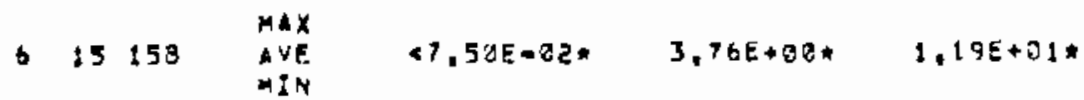

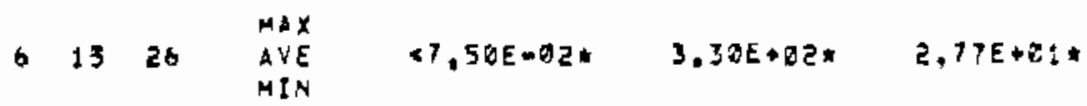

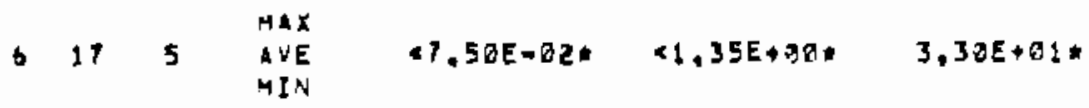

6.9903 MVE

6.19474 Mix

b 58 MAX
AVE

$\begin{array}{lll}\text { MAX } & \text { MVE } & 1.10 E+00 \\ 98,53 E-21\end{array}$

MIN
7, OOE-OI

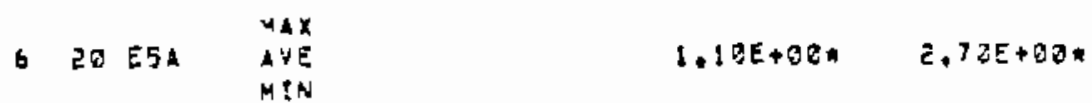

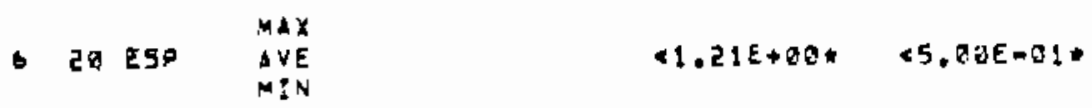

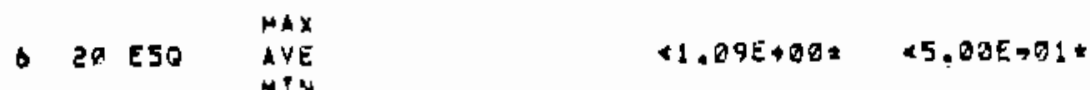

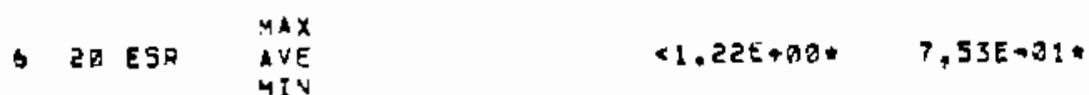

- 20 El2 MVE MIN

- 29 ELEP MHE

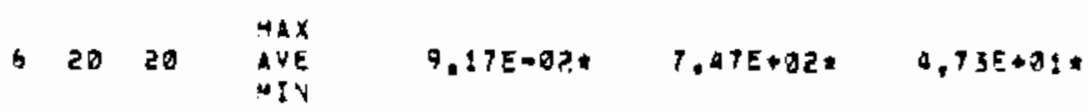


HELL $\$ 0$.

\begin{tabular}{rrr} 
POTAL FETA & TRITIUM & NITRATE \\
(PEI/ML) & $(P C I / M L)$ & $(M G / L)$ \\
\hline
\end{tabular}

\begin{tabular}{|c|c|c|c|c|c|c|}
\hline 6 & 20 & 39 & $\begin{array}{l}\text { MAX } \\
\text { AVE } \\
\text { YIN }\end{array}$ & & $\angle \$, 2 Z E \& D Q$ & $45,00 E-0: 1$ \\
\hline 6 & 22 & 70 & $\begin{array}{l}\text { MAX } \\
\text { AVE } \\
\text { MIN }\end{array}$ & & $1,03 E+01 *$ & $9,10 E+00$ \\
\hline 6 & 24 & IP & $\begin{array}{l}M A X \\
A \forall E \\
\text { MIN }\end{array}$ & & $<1.18 E+0 \%$ & $\angle 5,80 E-01+$ \\
\hline 6 & 24 & 10 & $\begin{array}{l}M \backsim X \\
\text { AVE } \\
M I N\end{array}$ & & $41,07 E 480$ & $45,00 E-05$ \\
\hline 6 & 24 & 12 & $\begin{array}{l}\text { HAX } \\
\text { IVE } \\
\text { MIN }\end{array}$ & & $41.12 E+60$ & $45,905=01$ \\
\hline 6 & 24 & 15 & $\begin{array}{l}M A X \\
\text { AVE } \\
M I N\end{array}$ & & $<1,37 E+08 *$ & $<5,00 E-01$ \\
\hline 6 & 20 & 17 & $\begin{array}{l}\operatorname{MAX} \\
A V E \\
M ! N\end{array}$ & & $9.23 E+80 *$ & $<5,00 E-0, *$ \\
\hline b & 20 & 33 & $\begin{array}{l}\text { MAX } \\
\text { AVE } \\
\text { MIN }\end{array}$ & $47.58 E-02 t$ & $2.38 E+92 k$ & $2,17 E+01 *$ \\
\hline 6 & 20 & 46 & $\begin{array}{l}\operatorname{MAX} \\
\text { MVE } \\
M \in N\end{array}$ & & $<9,23 E-81 *$ & $25.00 E-61 *$ \\
\hline 6 & 25 & 55 & $\begin{array}{l}\text { MAX } \\
\text { AVE } \\
\text { HIN }\end{array}$ & & $1.83 E+00 *$ & $1.25 E+01 *$ \\
\hline 6 & 25 & 70 & $\begin{array}{l}\text { HXX } \\
A V E \\
M I N\end{array}$ & & $7.25 E+a y *$ & $3,40 E+81 \div$ \\
\hline 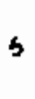 & 26 & 15 & $\begin{array}{l}\text { MAX } \\
\text { AVE } \\
\text { MIN }\end{array}$ & $1.47 E-0 \%$ & $1,8 ! E+83$ & $5, a \cap \varepsilon+a,=$ \\
\hline 6 & 26 & 89 & $\begin{array}{l}\text { MAX } \\
\text { IVE } \\
M I N\end{array}$ & & & $45.00 E-01 *$ \\
\hline 6 & 27 & 3 & $\begin{array}{l}M A X \\
A \cup E \\
\text { MIN }\end{array}$ & $\begin{array}{l}2.30 E-9 ! \\
1.75 E-91 \\
1.30 E-0 !\end{array}$ & $\begin{array}{l}9.40 E+02 \\
9.1 \partial E+92 \\
3.80 E+02\end{array}$ & $\begin{array}{l}5.0 Q E+0 ! \\
5.025+01 \\
4,62 E+0 !\end{array}$ \\
\hline 6 & 23 & 48 & $\begin{array}{l}M A X \\
A V E \\
M I N\end{array}$ & $4.50 E=02$ & $\begin{array}{l}3,50 E+01 \\
3,47 \varepsilon+121 \\
9,59 E+00\end{array}$ & $\begin{array}{l}1.30 E+01 \\
1.14 E+81 \\
9.50 E+00\end{array}$ \\
\hline
\end{tabular}


WELL NO.

$\begin{aligned} \text { TOTAL SETA } & \text { TRITIUN } \\ \text { (PCIAML) } & \text { NITRATE } \\ \text { (PCIML) } & \text { (MGAL) }\end{aligned}$

\begin{tabular}{|c|c|c|c|c|c|c|}
\hline$B$ & 28 & $40 P$ & $\begin{array}{l}M A X \\
A V E \\
M I N\end{array}$ & & $2,10 E+\theta 0 *$ & $<5,0 D E=01$ \\
\hline 6 & 29 & 78 & $\begin{array}{l}\text { MAX } \\
\text { AVE } \\
M E N\end{array}$ & & $\begin{array}{l}<1.29 E+00 \\
<1.82 E+00 \\
<7.70 E-01\end{array}$ & $\begin{array}{l}2,30 E+00 \\
2,88 E+00 \\
1,90 E+80\end{array}$ \\
\hline 6 & $3 !$ & 31 & $\begin{array}{l}M A X \\
\text { MVE } \\
M I N\end{array}$ & $4.5 \mathrm{~d} \varepsilon-\partial{ }^{2}$ & $\begin{array}{l}1.33 E+a 3 \\
1.15 E+03 \\
1.62 E+d 3\end{array}$ & $4.33 E+05 *$ \\
\hline 6 & 31 & $3 ! P$ & $\begin{array}{l}M A X \\
\text { AVE } \\
\text { MIN }\end{array}$ & & $\begin{array}{l}1.22 E+03 \\
0.25 E+22 \\
1.12 E+08\end{array}$ & $\begin{array}{r}0.70 E+7 ! \\
3.33 E+01 \\
\times 5,00 E=01\end{array}$ \\
\hline 6 & 31 & 310 & $\begin{array}{l}\text { MAX } \\
\text { AVE } \\
\text { MIN }\end{array}$ & & $5,90 E+00 *$ & $<5,00 E-21 *$ \\
\hline 6 & 31 & 539 & $\begin{array}{l}\text { MAX } \\
\text { AVE } \\
\text { HIN }\end{array}$ & & $<1,10 E+00 *$ & $5.20 E+00$ \\
\hline 6 & 31 & 65 & $\begin{array}{l}\text { MAX } \\
\text { IVE } \\
\text { MIN }\end{array}$ & & $\begin{array}{r}1.12 E+09 \\
8.18 E-01 \\
\times 5.70 E-21\end{array}$ & $\begin{array}{r}3,2 \partial E+20 \\
9,25 E-21 \\
<5,2 J E-71\end{array}$ \\
\hline b & 32 & 23 & $\begin{array}{l}M A X \\
M V E \\
M I N\end{array}$ & $1.335=01$ & $1.27 E+33 *$ & $6.62 E+01 *$ \\
\hline 6 & 32 & 42 & $\begin{array}{l}M A X \\
A V E \\
M ! N\end{array}$ & & $4.87 E+82 \hbar$ & $5,75 E+00 *$ \\
\hline 6 & 32 & 03 & $\begin{array}{l}\text { MAX } \\
A V E \\
M I N\end{array}$ & & $1,33 \varepsilon+a z *$ & $1,70 E+91 \%$ \\
\hline$b$ & 32 & 62 & $\begin{array}{l}\text { MAX } \\
\text { AVE } \\
M I N\end{array}$ & & $1.96 E+70 \%$ & $2,60 E+01+$ \\
\hline$\Delta$ & 32 & 70 & $\begin{array}{l}\text { PAX } \\
\text { AVE } \\
\text { UIN }\end{array}$ & $47,5 \partial E-0 E$ & $\begin{array}{l}4,42 E+C ? \\
2,52 E+E^{2} Z \\
1,00 E+62\end{array}$ & $\begin{array}{l}1.95 E+9: \\
1.585+2 ! \\
1.45 E+0 !\end{array}$ \\
\hline 6 & 32 & 72 & $\begin{array}{l}\operatorname{MAX} \\
\text { AVE } \\
\text { MIN }\end{array}$ & & $\begin{array}{l}1,50 E+92 \\
1.4 A E+12 \\
1,32 E+02\end{array}$ & $\begin{array}{r}5,80 E+92 \\
3.23 E+90 \\
\times 5,22 E=29\end{array}$ \\
\hline 6 & 32 & 77 & $\begin{array}{l}\text { MAX } \\
M V E \\
M I N\end{array}$ & $\begin{array}{l}<7.50 E-92 \\
<7.50 E-92 \\
<7.50 E=02\end{array}$ & $\begin{array}{r}2.90 E+87 \\
1.45 E+3 a \\
<6.10 E-81\end{array}$ & $\begin{array}{l}4.80 E+3 ! \\
3.14 E+9 ! \\
2.23 E+3 !\end{array}$ \\
\hline b & 33 & 42 & $\begin{array}{l}A A X \\
E V E \\
M I N\end{array}$ & $27,5 J E-02$ & $2.83 t+32 *$ & $1.53 E+01 \%$ \\
\hline
\end{tabular}




\begin{tabular}{|c|c|c|c|c|c|c|}
\hline \multicolumn{4}{|c|}{ WELL NO, } & \multirow{2}{*}{ 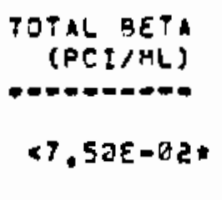 } & \multirow{2}{*}{$\begin{array}{l}\text { PRITIUM } \\
\text { \{PEIIML) } \\
0=0-0= \\
\text { Q,70E-21: }\end{array}$} & \multirow{2}{*}{ 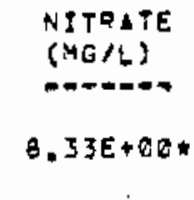 } \\
\hline 6 & 33 & 56 & $\begin{array}{l}M A X \\
M V E \\
M I N\end{array}$ & & & \\
\hline 6 & 36 & $39 \mathrm{~A}$ & $\begin{array}{l}M \perp X \\
A \cup E \\
H I N\end{array}$ & $<7.505-02 *$ & $5.97 E+02 *$ & $3.83 E+01 \leqslant$ \\
\hline 6 & 36 & 42 & $\begin{array}{l}\text { MAX } \\
\text { AVE } \\
\text { MIN }\end{array}$ & $c 7.50 E-22$. & $4,55 E+22 *$ & $3,00 E+91 *$ \\
\hline 6 & 34 & 51 & $\begin{array}{l}\text { MAX } \\
\text { AVE } \\
\text { MIN }\end{array}$ & $<7.58 E-02 *$ & $1.88 E+00$ & $8.20 E+\nabla \theta *$ \\
\hline 6 & 35 & 9 & $\begin{array}{l}\text { MAX } \\
\text { AVE } \\
M I N\end{array}$ & $<7.508-02 *$ & $1.19 E+\nabla 2=$ & $1.95 E+01 *$ \\
\hline 6 & 35 & 66 & $\begin{array}{l}M \triangle X \\
M V E \\
M I N\end{array}$ & $\begin{array}{l}\angle 7,50 E-0 Z \\
\angle 7,50 E=02 \\
<7,50 E-0 Z\end{array}$ & $\begin{array}{l}5.60 E+02 \\
7.56 E+02 \\
5.09 E+02\end{array}$ & $\begin{array}{l}2.305+91 \\
2,16 E+01 \\
2,10 E+01\end{array}$ \\
\hline 6 & 35 & 78 & $\begin{array}{l}\text { MAX } \\
\text { AVE } \\
\text { MIN }\end{array}$ & $\begin{array}{r}1,29 E=0 ! \\
8.88 E-02 \\
<7,50 E-02\end{array}$ & $\begin{array}{l}7.80 E+83 \\
7.33 t+83 \\
6.90 t+83\end{array}$ & $\begin{array}{l}3,605+21 \\
2,75 E+01 \\
2,18 E+01\end{array}$ \\
\hline 6 & 35 & 78 & $\begin{array}{l}\text { MAX } \\
\text { AVE } \\
\text { MIN }\end{array}$ & $\begin{array}{l}<7,5 \Delta E-02 \\
<7,50 E-12 \\
<7,50 E-02\end{array}$ & $\begin{array}{r}1,2 D E+00 \\
3,4 D E=01 \\
+7,6 D E=81\end{array}$ & $\begin{array}{r}1,90 E+00 \\
1,23 E+20 \\
<5,20 E-01\end{array}$ \\
\hline b & 36 & 968 & $\begin{array}{l}\text { MAX } \\
\text { IVE } \\
\text { MIN }\end{array}$ & & $\angle B, B O \bar{E}-\partial i \hbar$ & $<5, a \partial E-01 \div$ \\
\hline$b$ & 36 & 960 & $\begin{array}{l}\text { MAX } \\
\text { AVE } \\
M I N\end{array}$ & & $1.36 E+00$ & $7,20 E-91 *$ \\
\hline 6 & 36 & 611 & $\begin{array}{l}\text { MAX } \\
\text { IVE } \\
\text { MIN }\end{array}$ & & & $\begin{array}{l}2,60 \varepsilon+01 \\
1,715+01 \\
1,3 \Delta E+01\end{array}$ \\
\hline s & 36 & 93 & $\begin{array}{l}\text { HAX } \\
\text { AVE } \\
\text { MIN }\end{array}$ & & $<1,28 E+80$. & 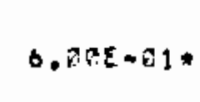 \\
\hline 6 & 37 & 43 & $\begin{array}{l}\text { MAX } \\
\text { AVE } \\
\text { MIN }\end{array}$ & $<.50 E-02 t$ & $6.90 E+011$ & $1,20 E+31$. \\
\hline$\$$ & 37 & $82 \mathrm{~A}$ & $\begin{array}{l}\text { WAX } \\
\text { VVE } \\
M I N\end{array}$ & & $\begin{array}{l}67,28 E=01 \\
<6,45 E-3 ! \\
45,90 E-91\end{array}$ & $\begin{array}{l}5,3 \partial E+91 \\
4,8 \Delta E+9 ! \\
9,4 J E+5 !\end{array}$ \\
\hline 6 & 30 & 65 & $\begin{array}{l}\text { MAX } \\
\text { AVE } \\
\text { MIN }\end{array}$ & & $5,30 E+99 *$ & $5,77 E+01 *$ \\
\hline
\end{tabular}


WELL ND.

- 3870 Max

iा IN

(1) $\$$

$63939 \quad 4$

(2) $M$

63970

AVE

MIN

- ab 1

MAX

AVE

$M I N$

640332

$M A X$

AVE

- a $6 a$ MAX

M!

4423

$\max$

AYE

- $42 \pm 2 A$ AVE

AIN

- 43 BA AVE

$\operatorname{mix}$

MAX

34460

AVE

$M I N$

645 Qz UVE

4 !

$45 \quad 69 \quad M A X$

D 4569 AVE

846 21 $1 V$

MIN

64735 MAE

MIN

$H A X$

647 ab $\triangle V E$
TOTAL BETA

(PCI/ML)

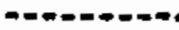

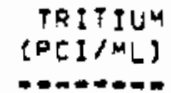

NITEATE

(MG/L)

- $-\infty-\infty$

$2.02 E-01 . \quad 3.20 E+01 * \quad 2.97 E+22 *$

$<7,50 E-02 *<9,20 E-01 * \quad<5,00 E-01 *$

$4.59 E-22 \quad<1.29 E+0, \quad 1.225+90$

$4.505-22 \quad 9,55 E-01 \quad 1,0,1]+70$

$<, 50 E-6 t 2$

$<5.7 \mathrm{ZE}=91$

6. $20 E-5 !$

$1.70 E+02 * \quad 2,405+8 ! *$

$3.77 E+91 * 1,325+90 *$

$1.90 E+81$

$B .55 E+00$

3. 9 i) $E+20$

$1.72 E+91$

$1.60 E+91$

$1.5 A E+01$

8,33E+32* T,90E+82* 7, 27E+01*

$.7,5 a E-82$.

3. $27 E+92=$

$2.83 E+21 *$

$41,40 \varepsilon+90$

$<8,7$ AE -21

$2.30 E+01$

CS. Bat-a 1

1. . WE + B I

<1, $12 E+23$

$<9.05 t-01$

$7,5 A E-\pi:$

$<8.30 t-101$

$1+8+5 E+01$

$1.58 E+01$

$1.70 E+3 !$

$47.50 E-02$
$47.50 E-92$
$47.50 E-92$

$3.2 a E+02$

$3.17 t+6 z$

$5,30 E+20$

$3,42 E+42$

$3,75 E+02$

C. $74 E-21$

$47.50 E-020$

$Q 9,03 E-E ! *$

$2,73 E+21 *$

$\checkmark 7.52 E-02 *$

$1.935+01 *$

$8.67 E+82$.

<9, 8तE-O I

$47,93 E-01$

4. ควE-Z:

$<5,99 E-61$

<5, RUE $=61$

$45.20 \mathrm{DE}=1$

$<1$, त2E+

$<8,35 \mathrm{E}-\theta$ !

$1.6 D E+01$

$1,11 E+01$

$.7 .506-02$.

1. $20 \mathrm{E}+0 \mathrm{O}$ 
WELL NO.

\begin{tabular}{|c|c|}
\hline $\begin{array}{l}\text { TOTAL BETA } \\
\text { (PCI/AL) }\end{array}$ & $\begin{array}{l}\text { TRITIUM } \\
\text { (PCI/ML) }\end{array}$ \\
\hline
\end{tabular}

\begin{tabular}{|c|c|c|c|c|c|c|}
\hline 6 & 47. & 60 & $\begin{array}{l}\text { MAX } \\
\text { IVE } \\
M ! N\end{array}$ & $\begin{array}{r}2,305-01 \\
1.14 E-01 \\
<7.50 E-02\end{array}$ & $\begin{array}{r}5.70 E+00 \\
3.02 E+00 \\
<0.09 E-01\end{array}$ & $\begin{array}{l}2 . \Delta E E+\theta 1 \\
2,28 E+91 \\
1.78 E+81\end{array}$ \\
\hline$b$ & 08 & $7 !$ & $\begin{array}{l}M A X \\
\text { AVE } \\
M I N\end{array}$ & & $\begin{array}{l}\angle .3 Q E+09 \\
\angle 9.25 E-01 \\
<6.72 E-09\end{array}$ & $\begin{array}{l}2.30 E+81 \\
1.25 E+01 \\
0,6 E E-01\end{array}$ \\
\hline b & 49 & 55 & $\begin{array}{l}M A X \\
M V E \\
M: N\end{array}$ & $\begin{array}{l}<7,30 E-22 \\
<7,50 E=82 \\
<7,5 J E-82\end{array}$ & $\begin{array}{l}<1.09 t+30 \\
<8,58 E-a 1 \\
<6,72 E-91\end{array}$ & $\begin{array}{l}1.00 E+01 \\
6.50 E+00 \\
4.50 \varepsilon+20\end{array}$ \\
\hline$b$ & 49 & 57 & $\begin{array}{l}\text { MAX } \\
\text { AYE } \\
M Y N\end{array}$ & $\begin{array}{l}1.13 E+D 0 \\
9.93 E=11 \\
0.80 E-B !\end{array}$ & $\begin{array}{l}1 . \Delta 0 E+B 2 \\
1.5 U E+\Delta z \\
1.4 \partial E+d 2\end{array}$ & $\begin{array}{l}1.80 E+02 \\
1.53 E+02 \\
1.4 \partial E+22\end{array}$ \\
\hline$b$ & 99 & 79 & $\begin{array}{l}\operatorname{MAX} \\
\text { RYE } \\
\operatorname{MIN}\end{array}$ & . & $\begin{array}{l}<2.10 E+01 \\
<2.17 E+20 \\
<5.90 E-01\end{array}$ & $\begin{array}{l}9,1 U E+21 \\
3,9 \partial E+01 \\
3,9 \partial E+01\end{array}$ \\
\hline$b$ & 50 & $2 \otimes B$ & $\begin{array}{l}M A X \\
M V E \\
M I N\end{array}$ & $47.50 E=12 *$ & $\begin{array}{r}3,29 t+01 \\
6,28 E+00 \\
<5,9 \Delta E-91\end{array}$ & $\begin{array}{r}2,20 E+a D \\
1, b 2 E+0 a \\
-5,20 E-01\end{array}$ \\
\hline$b$ & 50 & 30 & $\begin{array}{l}\text { MAX } \\
\text { AVE } \\
\text { MIN }\end{array}$ & & $\begin{array}{l}<1,30 E+90 \\
<9,33 E-01 \\
<6,10 t-01\end{array}$ & $\begin{array}{r}5,42 E+80 \\
3,23 E+00 \\
<5,00-01\end{array}$ \\
\hline 0 & 52 & 42 & $\begin{array}{l}\text { MAX } \\
\text { AVE } \\
\text { MIN }\end{array}$ & & $\begin{array}{r}1.10 E+00 \\
8.65 E-01 \\
<7.30 E-0 !\end{array}$ & $\begin{array}{l}5 ., U E-21 \\
5.8 J E=01 \\
<5,3 D E=01\end{array}$ \\
\hline 0 & 50 & 53 & $\begin{array}{l}\text { MAX } \\
\text { MVE } \\
\text { MIN }\end{array}$ & $\begin{array}{r}1, B 2 E-01 \\
1.41 E=0 ! \\
+1,50 E=02\end{array}$ & $\begin{array}{r}3,70 E+00 \\
1.63 E+00 \\
\times 7.82 E-01\end{array}$ & $\begin{array}{l}5,12 E+71 \\
3,73 E+Q 1 \\
2,32 E+01\end{array}$ \\
\hline 6 & 50 & 85 & $\begin{array}{l}\operatorname{MAX} \\
A V E \\
M I N\end{array}$ & & $\begin{array}{l}<1.4 U E+110 \\
<1.74 E+119 \\
<7.10 E-91\end{array}$ & $\begin{array}{l}2,10 E+Z 1 \\
1.70 E+01 \\
1.13 E+01\end{array}$ \\
\hline$b$ & 51 & 63 & $\begin{array}{l}\text { MAX } \\
\text { AVE } \\
\text { AIN }\end{array}$ & & $\begin{array}{l}1.20 E+00 \\
\times 9.58 E-11 \\
<7.8 B E-B 1\end{array}$ & $\begin{array}{r}4,50 E+02 \\
2,43 E+20 \\
<5,78 E-21\end{array}$ \\
\hline 6 & 51 & 75 & $\begin{array}{l}\text { MAX } \\
\text { AVE } \\
\text { MIN }\end{array}$ & & $\begin{array}{l}<1.52 E+919 \\
<9.79 E-01 \\
<5.87 E-111\end{array}$ & $\begin{array}{l}<.20 E-71 \\
<5, \partial G E-71 \\
<5,0 \partial E-21\end{array}$ \\
\hline$b$ & 53 & 35 & $\begin{array}{l}\text { RAX } \\
\text { AVE } \\
\text { MIN }\end{array}$ & & $\begin{array}{r}60,72 E-21 \\
7,90 E-9 ! \\
7.30 E=01\end{array}$ & $\begin{array}{l}<5,0.0 E=21 \\
<5,90 E=21 \\
<5,04 E-01\end{array}$ \\
\hline$b$ & 53 & 47 & $\begin{array}{l}\text { MAX } \\
\text { AVE } \\
\text { MIN }\end{array}$ & & $\begin{array}{l}<8.3 D E-91 \\
<7.2 M E-D 1 \\
<5.81 E-91\end{array}$ & $\begin{array}{l}<5,0 \triangle E-91 \\
<5, B \nabla E-\square 1 \\
<5,20 E-b 1\end{array}$ \\
\hline
\end{tabular}




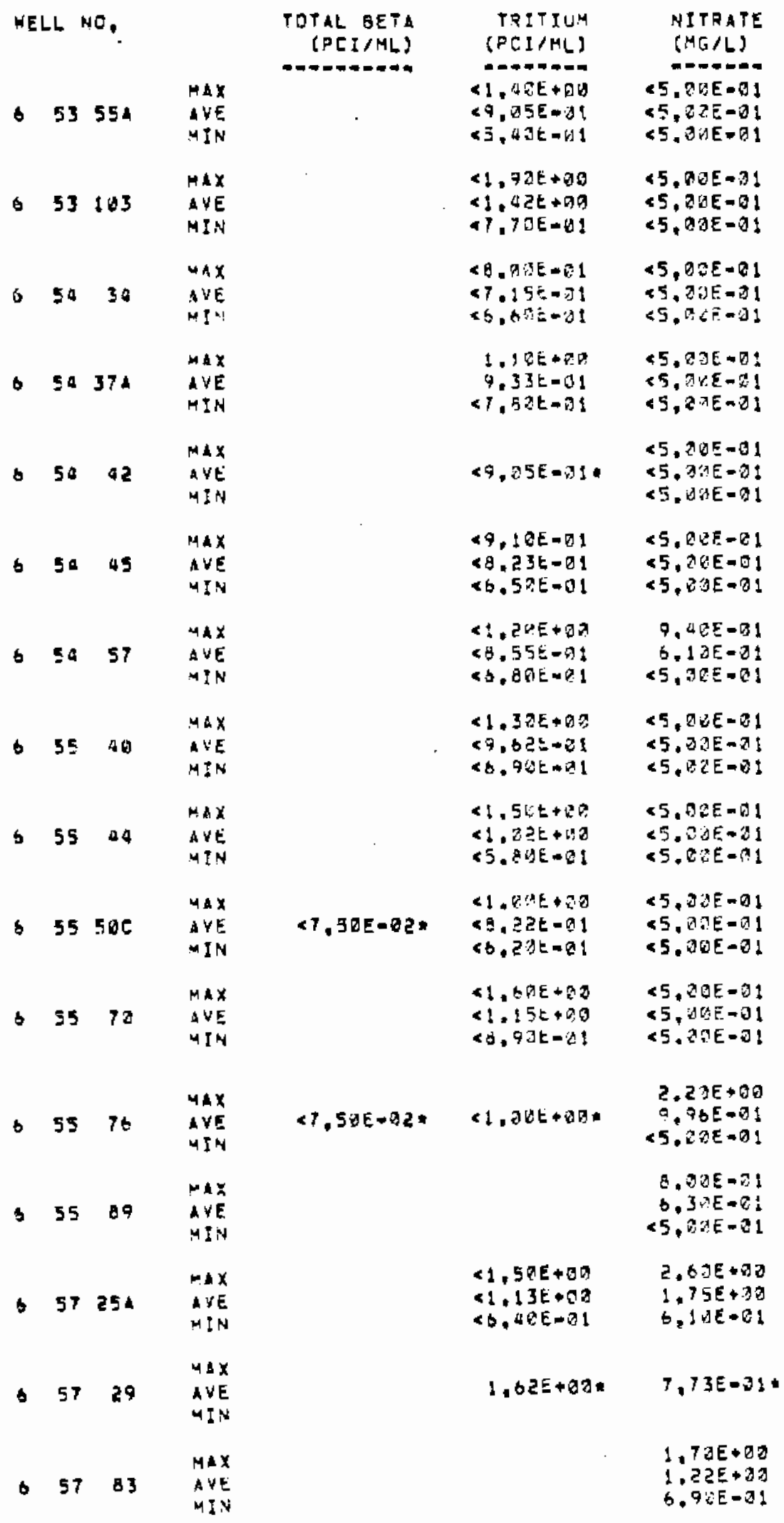


MELL NO.

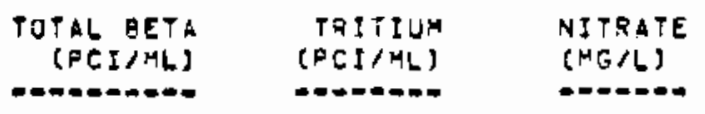

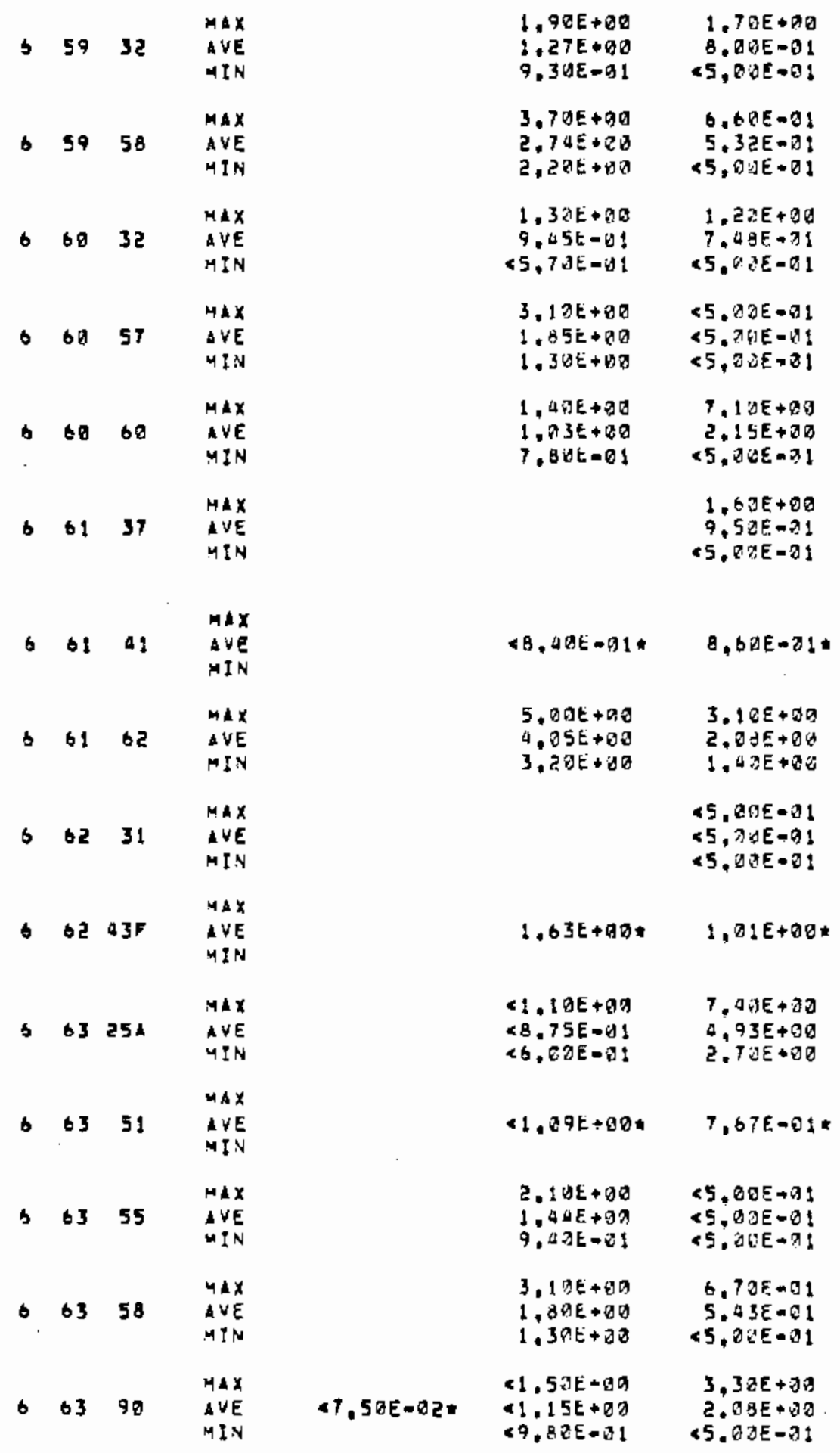


HELL NO.

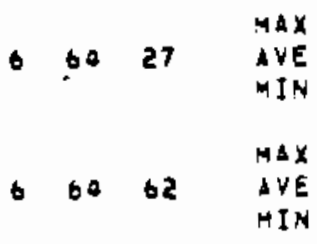

$6 \quad 6522$ MAX

$605.38 \quad M V E$

66550

ax

$6 \quad 559$ AVE

$M I N$

- 6572 HAX

MIN

$6583 \quad$ MAX
GIE

MIN

66638 AVE

MIN

66639 MYE

CAX

b G6 58 AVE

b to ba M MEX

666123 MVE

\begin{tabular}{|c|c|}
\hline 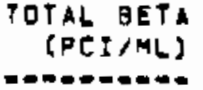 & $\begin{array}{l}\text { TRIT!UM } \\
\text { (FCI/HL) } \\
\text { - }\end{array}$ \\
\hline
\end{tabular}

$4.98 E-01 * \quad 2.27 E+00 *$

$\begin{array}{ll}2.50 E+00 & 8.00 E-0 ! \\ 2.03 E+00 & 6.55 E-01 \\ 1.50 E+20 & 5.81 E-01\end{array}$

$\angle, B Z E-D I$ : $8,40 E+O B$.

$\angle 0,10 E-0.40 \quad<5,00 E-9 !$

$\begin{array}{ll}7.00 E+0 \theta & 9.30 E-0 !\end{array}$

$1.42 E+00 \quad 5.65 E-01$

$2.33 E+00 * \quad 5.25 E-01 *$

$1.3 B E+00 \quad 5,03 E+00$

$9.45 E-81 \quad 9.73 E+Q 8$

Q7.DUE-RI $4,3 \times E+90$

$1.8 V E+20 \quad 3.30 E+30$

$1.31 E+00 \quad 1.60 E+00$

$9.50 E-01<5,00 \varepsilon-2 !$

$<5,205-21 *$

<. ACE-จ!

<. $20 E-91$

$<5.205-0 !$

3. $D A E+Q 0$

$2.32 E+00$

$7.70 E-0 !$

6. टTE-3!

$5,2 U E N \rightarrow$ !

$1.5 \pi E+20$

$8,905-01$

$1,23 E+20 \quad 7,83 E-01$

$8,2 \Delta E-015,80 E-D 1$

<8, 15E-82* <5, A2E-B!* 


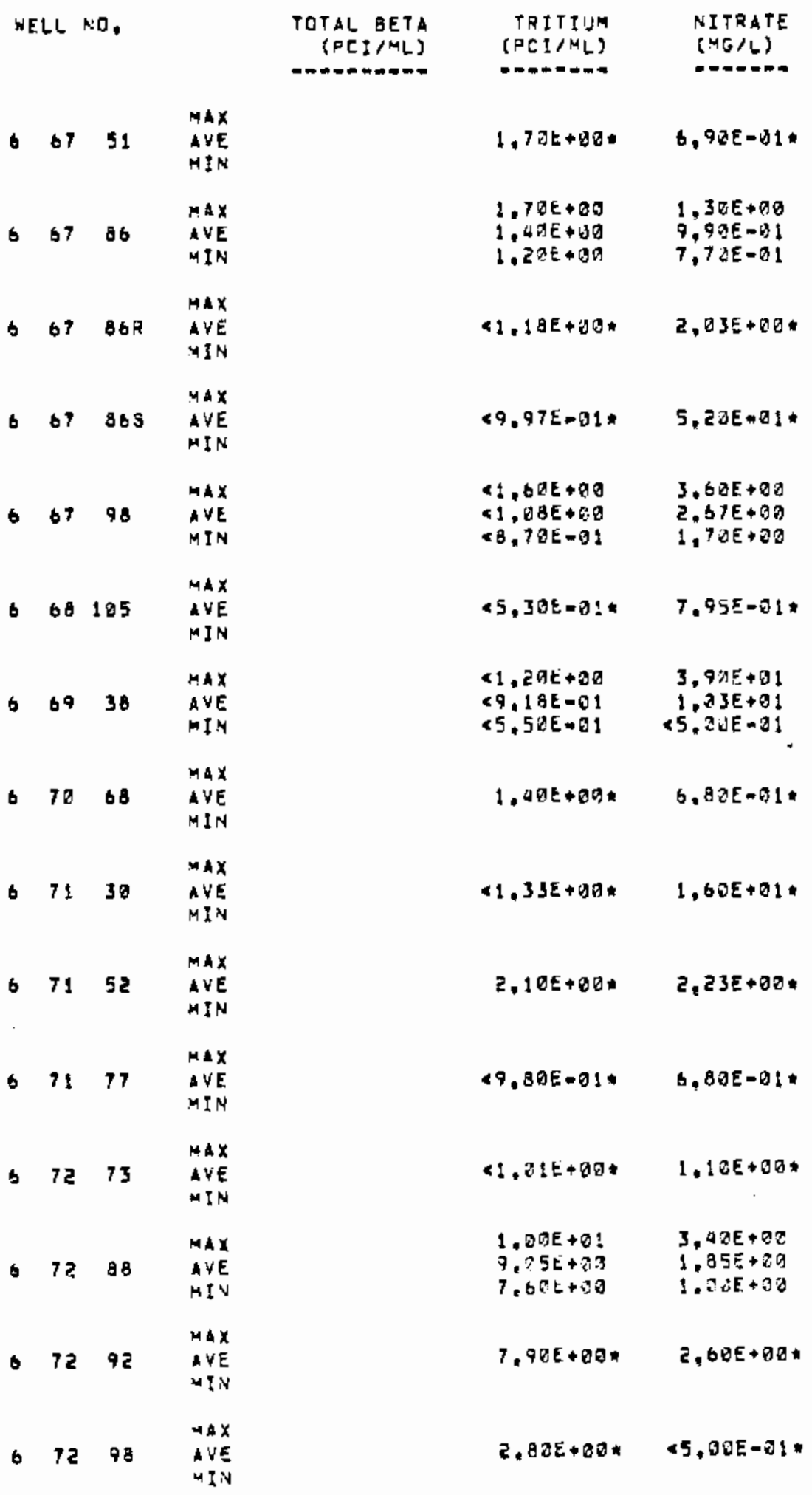


AELL NO.

- 73 OI AVE

b 74 A4 AVE

$74 \quad H A X$

$M ! N$

$B 7730$ MVE

64 4 AX

$6775 a \quad 4 V E$

MAX

- Ta G2 AVE

MIN

G $\operatorname{MAX}$

680435 AVE

$M I N$

- 1 so MAX

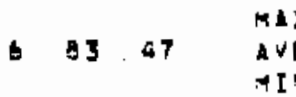

- 007540 MAX

G IVE

- 3755 AVE

MIN

$\checkmark A x$

- $89 \quad 35 \quad 2 V E$

$M A$

- $90 \quad 45 \quad A V E$

MIV

$44 X$
$M I N$

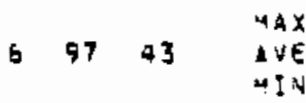

TOTAL BETA TRITIUM NITRATE
(PCI/ML) SPCI/ML)

(M-O)

$\angle B, 2 \partial E-01 * 2.30 E+\partial \theta \star$

$<1.70 E+03 \quad<5.00 E-01$

$\angle 1.10 E+0 B \quad \angle 5,00 E-01$

$\angle 5, \triangle A E=01<5,00 E-91$

$\angle 1,60 E+28+\quad \pm, 60 E+60 *$

$<1.70 E+90 \quad 2.29 E+92$

$<1.58 t+09 \quad 2,325+92$

$<5,905-01 \quad 1.825+02$

$3,77 \varepsilon+00 \%$

$3.135+80$

$2,09 E+00+$

$<1,14 t+90 * \quad 5,20 E-01 *$

$<1.6 G E \leftrightarrow A D$.

$<1,00 E+00 * \quad 5,20 E-01 *$

$6.97 \varepsilon+8: * \quad 1,17 E+01 *$

$3.906+90 *$

$2.35 E+21 * \quad 5.028-31 *$

$2,37 E+3 ! * 7,33 E-81$

$9.3 \partial E+00 * \quad 3,90 E+00 *$ 


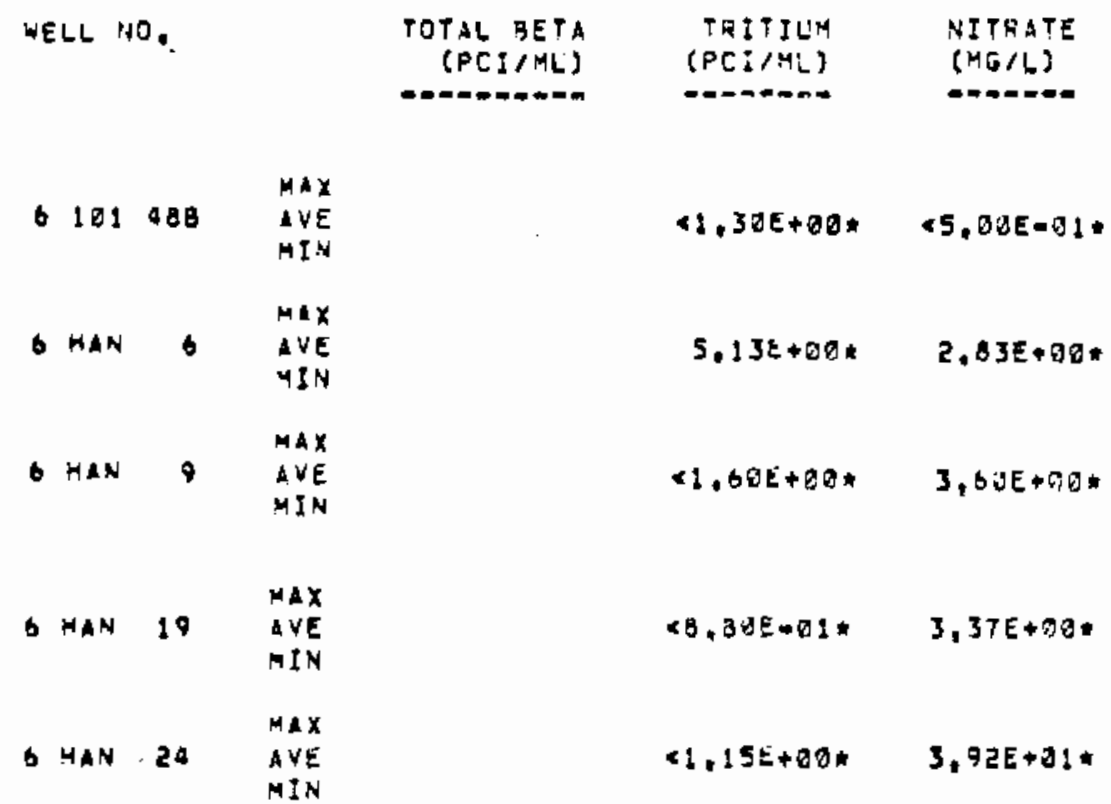


. 
APPENDIX B

B-1 
Total Alpha, Strontium, Cesium, Cobalt, Uranium, Ruthenium, Chromium and Fluoride Concentrations in the Ground-Water Unconfined Aquifer, Calendar Year 1978.

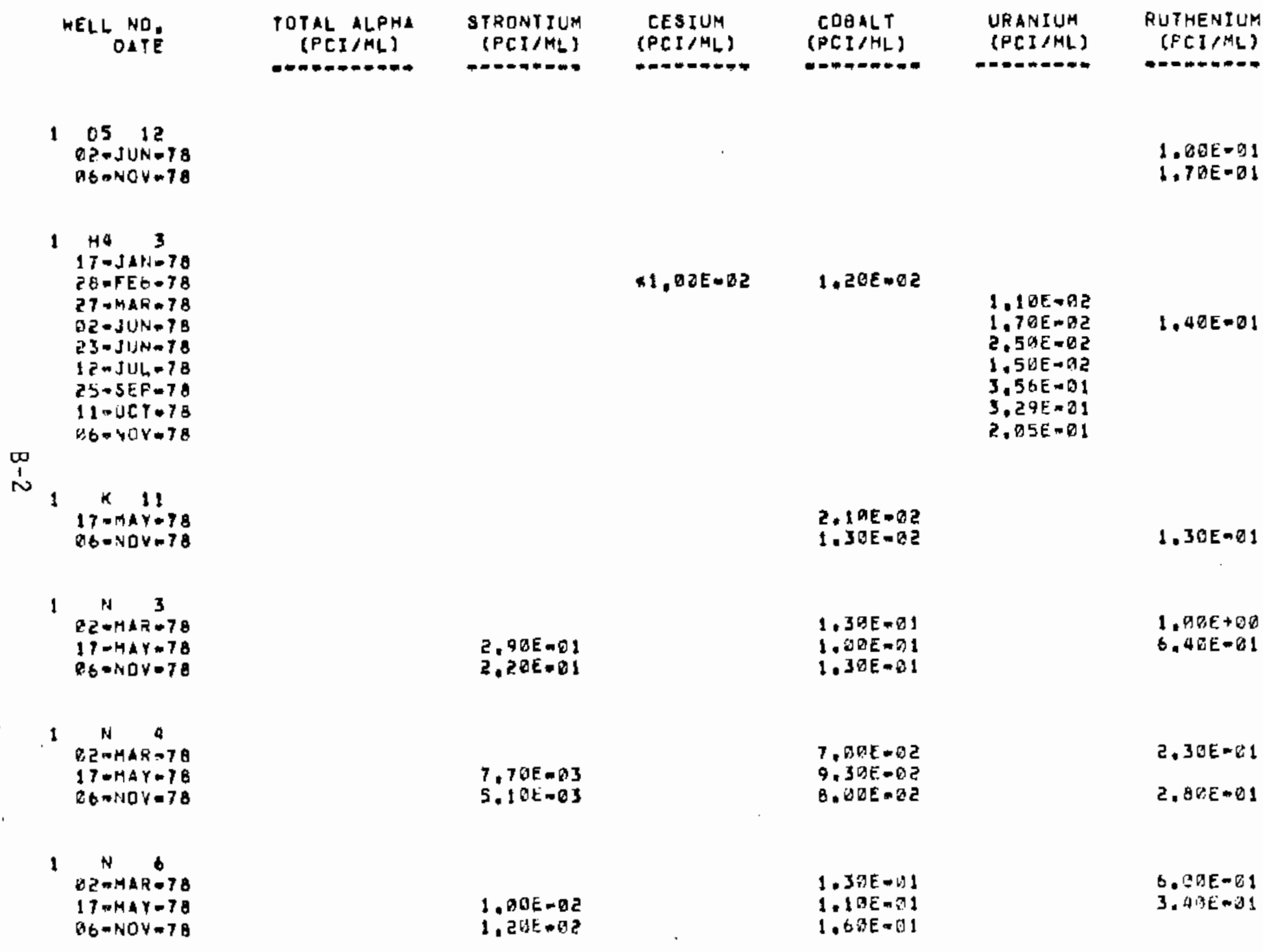

FLUORTDE (HG/L) ( $M G / L$ ) m-n-m-nom 


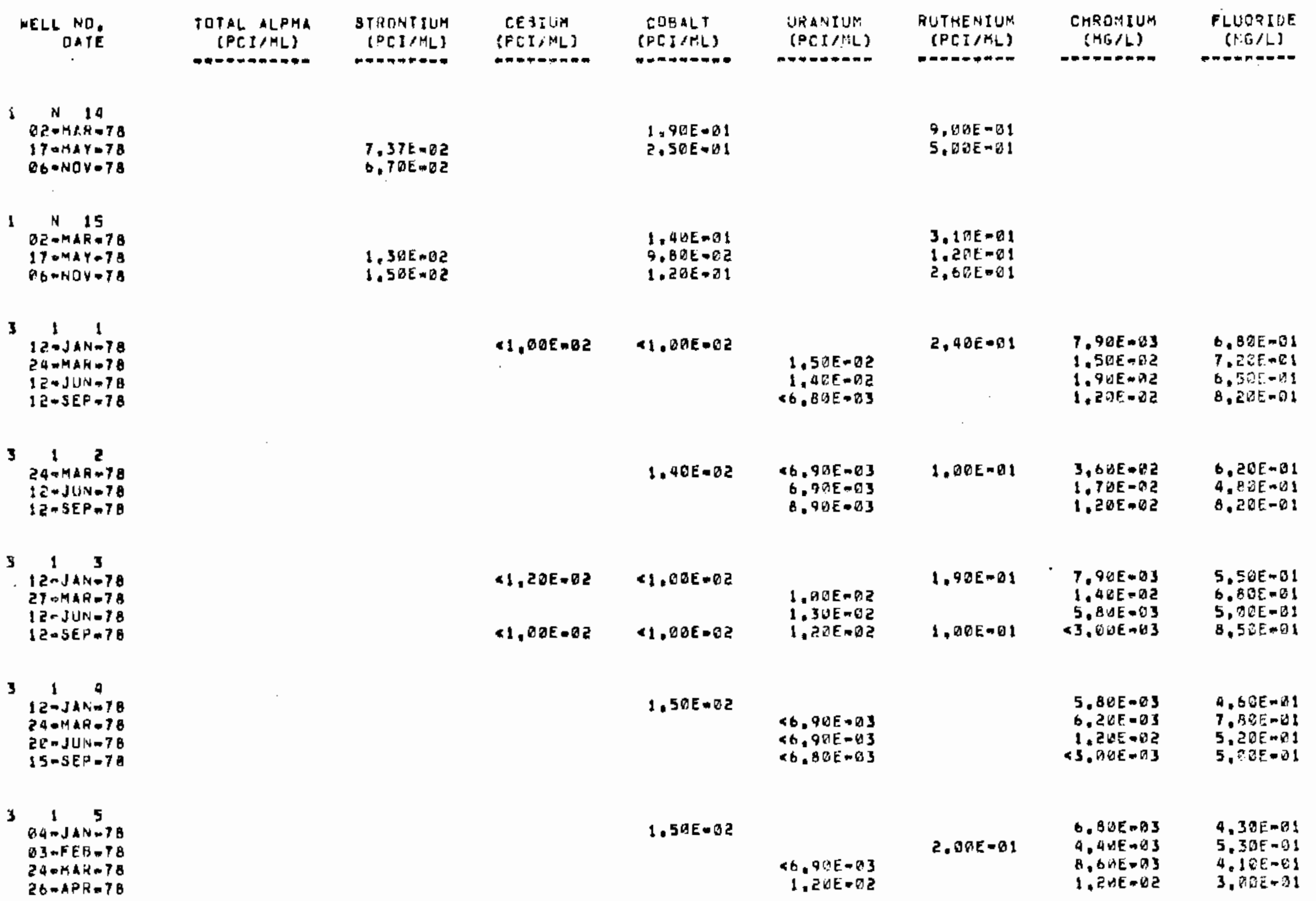




\section{HELL NOE \\ 315 \\ $16-M A Y=78$ 12-JUN-TB 11-JUL-18 07-AUG-18 15 $5 \mathrm{EP}-\mathrm{TA}$ $13-0 C T-78$ Ct $\rightarrow$ NOV $=7$ a $28-1,0 y-7$}

TOTAL ALPHA (PCI/ML)

316 12-JAN-TB Q8-AAR-T8 $24-\mathrm{HAK}-7 \mathrm{~B}$ $26-10 N=78$ 16-MAY-78 $3 x-J U N-78$ $20-J \mathrm{~N}=78$ $11-J U L-78$

co $15.5 E P=78$ $15-S E P=78$
$13-O C T=78$ $13-0 C T=78$
$A B-N Q V-18$ 2a-NOV-78

\begin{tabular}{|c|c|}
\hline 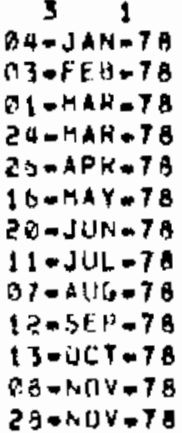 & 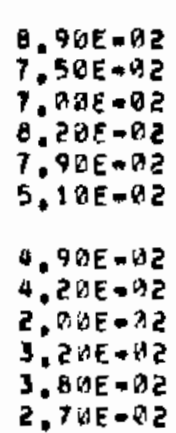 \\
\hline
\end{tabular}

332 $1 Z=\sqrt{2} 2$

\section{STRONTIUM} (PCI/ML)

\section{CESIIJH}

(PCI/ML)

COEALT

(PCI/ML)

(PCJ/ML)

RUTHEN IUM

(PCI/ML)

CHRDHIUM

(MG/L)

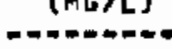

FLUORIDE

(MG/L)

-TM-P.

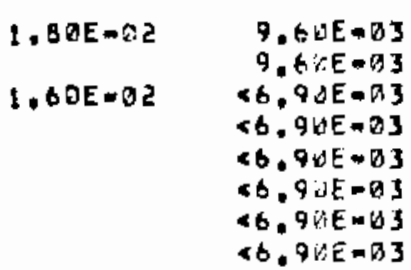

1. $18 E-G 2$

$1.16 E=22$

2, BUE $=2$ Z

$1,4 \triangle E-A 2$

$6,20 E=03$

C,

9. 3 , EE $=B 3$

$1.50 E=0 !$

$7,4 n E-13$

$0.305=81$

$1,23 E+23$

$1.00 t+3 \pi$

150E 51

$4,305-01$

$3,53 E \times B$

$5, \pi\left(x^{x}[-3)\right.$

$1.50 E$. 31

$\triangle 1,00 E-02$

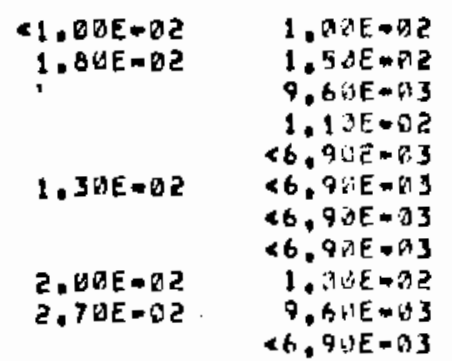

9.6OE- 13

$\theta \cdot z \theta E-\theta z$

1. IUENAE

$3.7 U E=92$

$1,7 \& E=Q 2$

$9.2 A E-A 3$

2.7 טE-Ra

$2.4 \Delta E=\mathrm{H} 2$

$2,245-92$

$1.60 E=01$
$1.55 E=01$

\section{$4.5 \forall E=013$}

<. $0.4 E-93$

$1.00 E=\square 2$

$4.5 .6 E=02$ $0,505-62$ $4.12 E-41$ $4.25 E-91$ $5,50-01$
$5,7 k=01$ $5.63 E-41$

$0.80 E-61$

4. *3ere! $5.43 \equiv-31$ $1,30=01$

$43,[10 E=B 3$

$5, B V E-B 3$

Q3. $A G E \operatorname{CH} 3$

$4,0 \triangle E=02$

<3. BAE-A3

$5.10 E-63$

1,1 HE $=\mathrm{GI}$

3. $1 H E=B 2$

Q. $4 G E=B 3$

$1.0 O E$ CA

$\angle 3, A B E=Q 3$

$\triangle 3, E=$ S

63 , UUERES

5. BดE $\rightarrow$ E 1

$7,325-01$

$4.60 E+81$

T. 2AE-31

1. 3., $12+110$

7. $20 E-D 1$

$7,20 E-D 1$

$5.50 E-41$

$6.50=01$

$7.50 E-81$

$4.23 E_{+} 81$

1. Bilk-

$1,7, A E=02$

$1.43 E-B)$

9. $52 \mathrm{E}-31$

$1.605 .01 \quad 3,42 E=01$ 


\begin{tabular}{|c|c|c|c|c|c|c|c|c|}
\hline WELL NOFE & 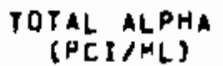 & $\begin{array}{l}\text { STRONTIUM } \\
\text { (PCI } / M L)\end{array}$ & $\begin{array}{l}\text { CESIUM } \\
(P C I / M L)\end{array}$ & $\begin{array}{l}\text { COHALT } \\
\text { (PCIMMIS) }\end{array}$ & $\begin{array}{l}\text { URANIUH } \\
\text { (PCIfML) }\end{array}$ & $\begin{array}{l}\text { RUTHENIUM } \\
\text { (PCI } / M())\end{array}$ & $\begin{array}{c}\text { CHROMIUY } \\
\text { (HG/L) }\end{array}$ & $\begin{array}{c}\text { FLUURDOE } \\
(N: G / L)\end{array}$ \\
\hline$\cdot$ & $\theta++\infty+\infty+\infty+\infty$ & 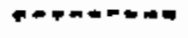 & 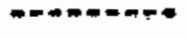 & $=-\infty+\infty+\infty \pi n$ & $-\infty+\infty+-0.00$ & 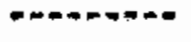 & $n=-\infty+\infty+\infty$ & $-0-0-0.0 \%$ \\
\hline 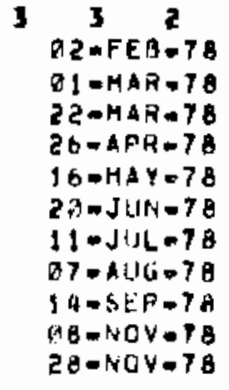 & 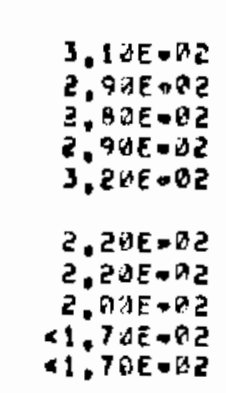 & & $<2,20 E-02$ & $3.00 E-02$ & 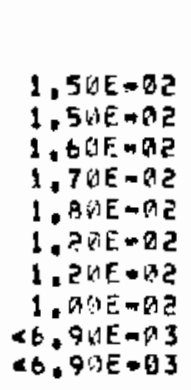 & $2.00 E-21$ & 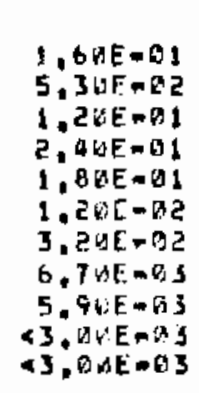 & 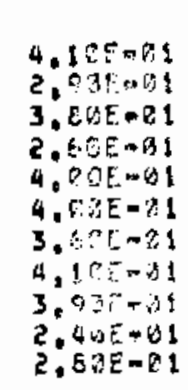 \\
\hline 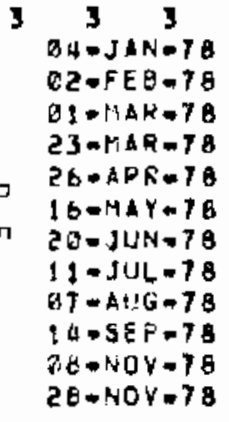 & 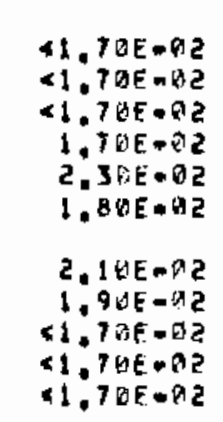 & & $<1,50 E=02$ & $3.00 E=02$ & 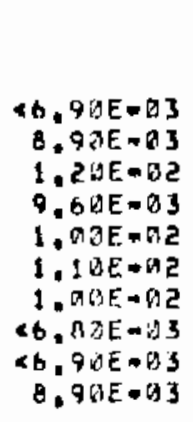 & $1.70 E=01$ & 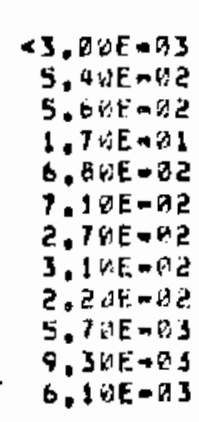 & 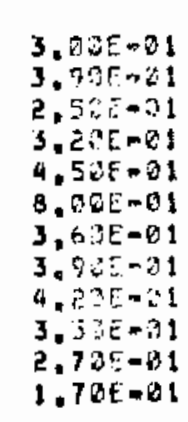 \\
\hline $3{ }_{3 \theta-M A R=78}^{3}$ & & & & & $26.93 \mathrm{En}, \mathrm{A} 3$ & & $<3,00 E=03$ & $2, \pi O E=61$ \\
\hline 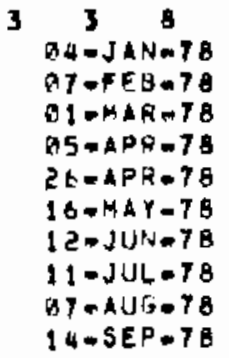 & 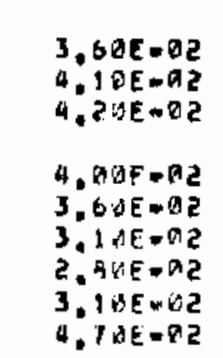 & $\begin{array}{l}0.16 E=02 \\
1,20 E=01 \\
1.12 E=01 \\
1.03 E=01 \\
0,70 E=01 \\
1,77 E=01 \\
1,40 E-01\end{array}$ & $\begin{array}{l}<1,50 E=02 \\
<1,50 E=02\end{array}$ & $\begin{array}{r}<1.00 E-02 \\
1.80 E-02\end{array}$ & 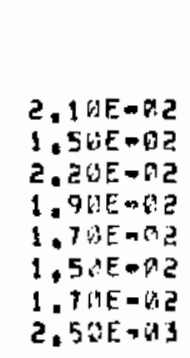 & $\begin{array}{l}1.00 E=01 \\
1.20 E=01 \\
8, U Q E-02\end{array}$ & 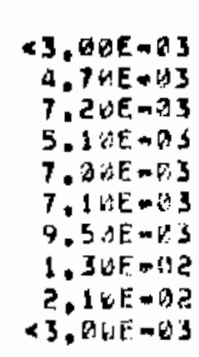 & 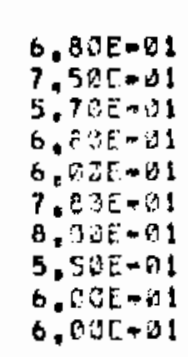 \\
\hline
\end{tabular}




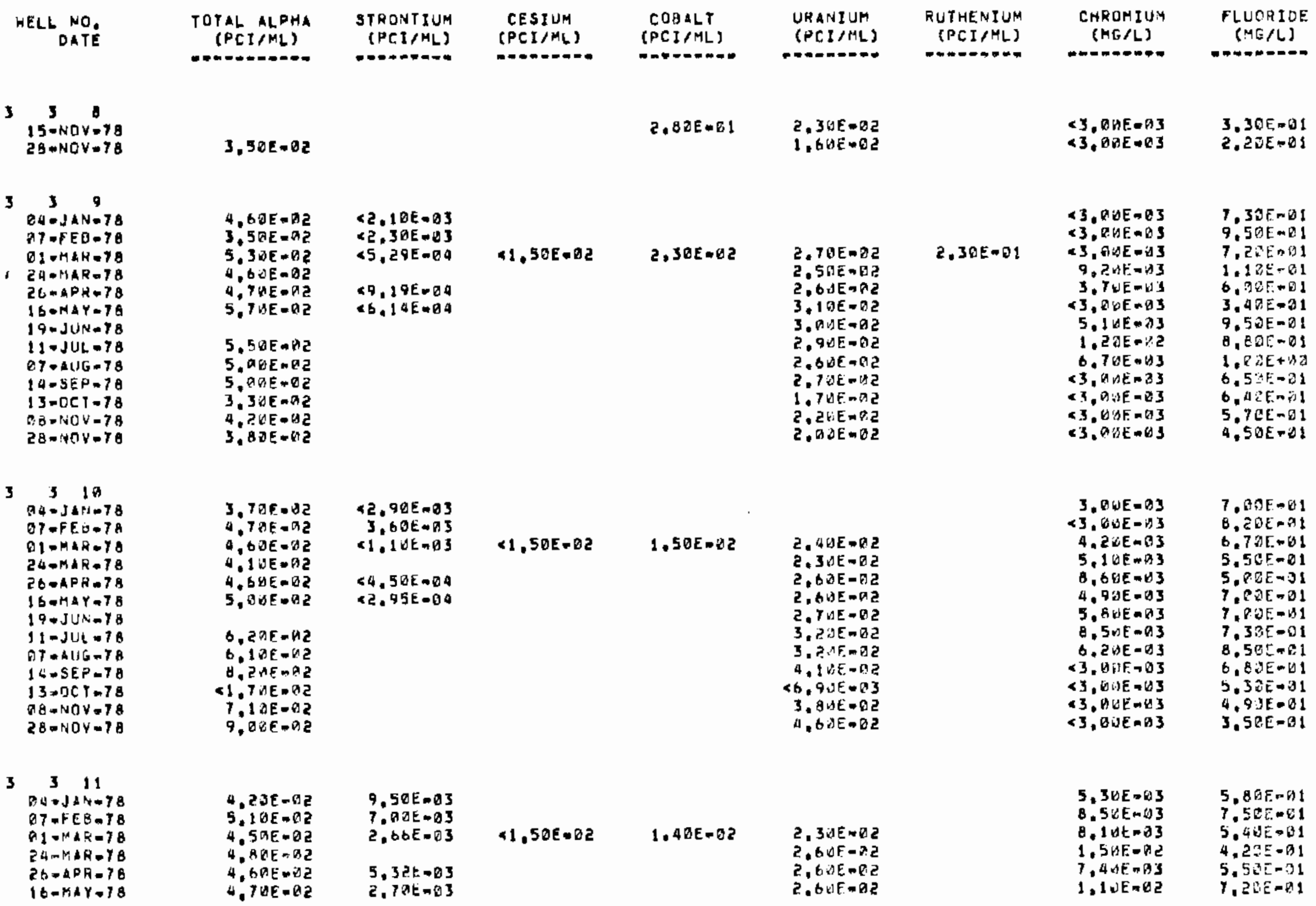


WELL NO, DATE

TOTAL ALPHA

(OEI $I M L)$

3311

19-JUN-78
$07=A \cup G=78$

34

11-JAN-78 $D B-M A H=7 B$

25-14A-7B

26 WAPR=78

16-MAYTIS

$19 m$ JUN-70

1 1) $-3 \cup L=7 B$

P T-AUG-7B

14 SEP-7

13-UCT-78

$D B=N D Y-73$

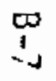

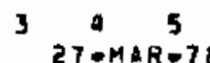

$20-J U N-78$

ด)-AUG-78

347

- $4-J A N-7 B$

97-FE $6-78$

AI THAR=7B

$24-M A R=7 \theta$

$2 b-A P \bar{X}-78$

$26-M 1 Y-78$

$2 B=J U N-7 \theta$

$11-514=78$

$07-146-78$

14 SEF-7日

$13-0 C T=78$

AB-NLY -78

$2 B M N O V-7 A$

$3{ }^{4}{ }^{9}$

$5.30 E-02$

9. $20 E-182$

$6,50 E=12$

$0.20 \mathrm{En} 2$

$6.50 E-B 2$

6. $8 \partial E-02$

$5,60 E-02$

$5.918 E-05$

6. $10 E-22$
STRONTIUM

(PCI/RL)

CESIUN

FCI/ML)

COBALT

(PCI/AL)

URAAIUS

(PCI/HL)

RUTHENIUM

(PCI/ML)

CHROMIUM

(MG/L)

-

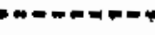

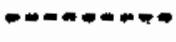

$1.90 E N B z$

$1.50 E-02$

$4.20 E=02$

$1.90 E-62$

$0.90 E=03$

$6.920=03$
$.6 .911 E A G 3$

$1.70 E-02 \quad 0.914 E M Q 3$

$46.93 E=03$

$0.9 .8 \mathrm{EMBS}$

$7.506-03$

$1.4 W E=92$

$1.5 \mathrm{SCO}=0$

1,3 E -8

3.006 .02

1,3
$1,3 E A D$

$1.20 E=01$

$1.20 E-62$

$1.0 \partial E=02$

1.27E-OJ

$1,50 \mathrm{E}=02$

$2.10 \varepsilon-02$

$3,3 \cup E=02$

3. $44 E=62$

3. $4 A E-\theta Z$

3. $1 \cap F=92$

5. $906-90$

$3,90 E-32$

Z. 3पF $\rightarrow$ G C

$46.8 \mathrm{E}=0 \mathrm{Z}$

$3,10 E-02$

3 1 1 DE-OZ

$3,308-02$
$3,00 E-82$

(n)

$9.20 E-03$

$4,80 E-93$

z. $20 E=05$

1. $5 \angle E-O L$

$1,206-01$

9, ZUE-OZ

$7.50 E-82$

$9,90 E=02$

$2.7 D E=92$

$43, A D E-B]$

$<3,4 \cup E=25$

$9,310 E-33$

2. 2 a $E=D 2$

$5,4 U E=03$

$9,90 E-92$

$1.90 E-103$

$8.50 E \rightarrow 03$

b. $2 \Delta E-B 3$

1. $2 U E+2$

$3,4 \Delta E=92$

$9 . Z Y E=13$

1. $50 E=33$

2. $24 E-D C$

$1,3,0=0 a$

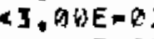

Q. QUE $A B 3$

4. $9 \& E=\square 3$

5. OHE.D 3

$9.00 E-02$

$6.10 E-03$

7. AGE +31

6, REFOI

$6,80 E+D 1$

4. IDEMDI

$3.73 E-D 1$

2. DoEनतa

3. तीe $=1$

4. $6,3 E-91$

4.28[- 2 [1

4, IUE-A!

3. QDE DDI

$4.50 E-81$

$3,30 E-0 !$

3. $3 J E=0$ !

$2,73 E-81$

$7.50 E \mathrm{DOL}$

$4.23 E-01$

$6.50 E-01$

$8,300-01$

$6,5{ }^{2} E-21$

$7.53 E=0 ?$

$5, C E E+21$

1.56E+R

6. $50 E-B 1$

B. Q2AE-OI

$7, \angle C E=01$

$6,5 B E-101$

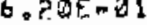

$3.82 E-01$
ATDE (MG/L)

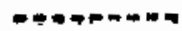

$1,88 E-03 \quad 4,20 E=02 \quad 1.60 E-02$

Q. BOE 
WELL ND.

TOTAL ALPHA
(PCIAML)
(PCIAML)

340

QT $A F E U=75$

OI MAHATS

2A-MHR-?B

$26 \rightarrow 104=78$

$16-M A Y-78$

19-JUN-7B

$11-\mathrm{JUL}=78$

ว7-AUG-7B

$15-5 F P=1 A$

$1300 C 7.7 B$

AB-NOY-78

$28=N O Y-18$

3210

94-JANI-7B

Q7 -FEU-78

BIFMAR 78

2 $4-M A R=78$

2E - APR $=78$

$160.44 Y=78$

GPYAY-1B

$15-J U N-78$

1) $-5 U L-1 B$

DT-AUSATB

1S-SEP-7Q

DE. NOY.7\%

28. NOY-TO

351

11. JAN-7B

ER-JUN-78

$14-5 E P-78$

3
$\underset{1=J A N A T B}{2}$
23.M4R.78
$26 \cdot J U ! U=78$
$12 \rightarrow S E P-7 B$

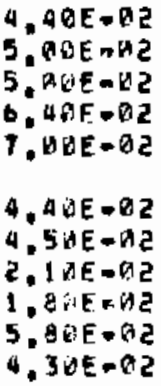

$12,10 E=03$

$44,53 t=04$

$41.502-03$

$2.90 E-03$

$<7.22 t-94$

$2, B A E=\sin$

$9,7 \cup E A B 2$

$4,6 a E-22$

$0.0 P E-02$

$\times 3,26 E=04$ $<2,526.03$ $47.73 z-09$

2. BOE-AS

$3,7 H E=82$

$3,6 \Delta E=02$

- Bar-a

$7, \triangle Q E=02$
$1.40 E-02$

$5,06 E=05$

$2.7 D E-D 2$

$3 . \Delta \cup E=\square ट$

$3.7 B E-02$

$3.7 \mathrm{AT}-8 \mathrm{Z}$

$2.4 .0 E-H E$

$2.49 E-92$

1. $1 F^{\circ} F_{-}-2$

$9, G B E-O B$

3. 1 तE $\triangle B$

$2,3 J E=D 2$

4.50E-02 2.70E-02 2.4UEN02

2. $40 E-62$

$1.06 E-03 \times 3.84 E+03$

]. $3 A E-D 2$

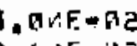

$5, b \cup E \rightarrow$ G

2. $2,1 \mathrm{E}-\mathrm{BI}$

$1,90 \mathrm{COC}$

$3.60 E-O Z$

3. $9 \cup E-02$

$41,20 E=02$

$2,10 E-T 2$

$1,70 E=02$

$<6,94 E-a 3$

$\angle 6.91 E=93$

$2.50 t-02$

$46.8 d E=03$

$\times 1,20 E+02$

$\operatorname{s.9} 9 E-95$

1.उดEन

$46,905=03$

$<6.9 A E-A 3$
RUTHER:IUM

(PCI/AL)

CHROMIUH

(MG

n-O-OAm

rLUOPICE

[NGtis

nam

9.1UEROS B.SBF-OI

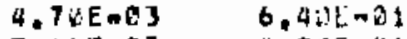

$5.4 A E=23 \quad 4.96 E-D 1$

2.3 $3 E=02 \quad 5.0 E=-11$

Q.2QE-0.3 7.2QF-R1

$1,4,1 E-\pi 2$ G. OOE- 1

1. $40 E M A 2$ G. $D O E-\theta 1$

1.6KEnHE $7.912-131$

$<3$.

<3. $\sin x \cos 3$

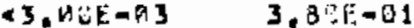

$\times 3.04 E-13$ 2. $2 E E-1$

4. THENOB

7. $4 \backsim E \cap D S$

$6.2 \cup E-B 3$

$1.3 \cap E=V ?$

$9,8 J E=03$

$2,39 \varepsilon-81$

$6.6,4 E-93$

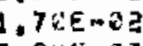

$5,9 \cup E-D 3$

3. $20 E=13$

$<3,64 E R O 3$

$5,0.0 E-03$

$7,3 x E=51$

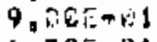
$6.725 m b 1$

$6.06 E-E^{2} !$

$5,53 E-d 1$

$6,205+61$

6. 50E-01

$9.50 \mathrm{~mol}$

$6.45 E-\angle 1$

$4.90 E-81$

$4.10 \mathrm{E}$ -

7. 9UE-OS

$2.5 \mathrm{DE} \cdot 0 \mathrm{CZ}$

$1.60 E-02$

$43,018 E-B 3$

$2,52 \mathrm{c}-31$

$3,10 \tau-01$

$3,50 E=0$ !

$3,63 E=01$

$1.40 E-81$

$5,00 E 003$

$7,80 E-b 3$

G, GUE + PS

$3,0 D E=31$

$6.60 E-21$

2. $B D E-3 !$

3. $\triangle 0 E-d:$ 


\begin{tabular}{|c|c|c|c|c|c|c|c|c|}
\hline \multirow[t]{2}{*}{$\begin{array}{l}\text { WELL NO, } \\
\text { OATE }\end{array}$} & $\begin{array}{c}\text { TOTAL ALPHA } \\
(P C J / M L)\end{array}$ & $\begin{array}{l}\text { 9TRONTIUM } \\
\text { (PCI/ML) }\end{array}$ & $\begin{array}{l}\text { CESIUM } \\
(P \subset Y / H L)\end{array}$ & $\begin{array}{c}\text { COAALT } \\
(\text { PCI/ML) }\end{array}$ & $\begin{array}{l}\text { URANIUM } \\
(P C I / M L)\end{array}$ & $\begin{array}{l}\text { RUTHENIUM } \\
\text { (PCII/HL) }\end{array}$ & $\begin{array}{c}\text { CHROMIUM } \\
\text { (MG/L) }\end{array}$ & $\begin{array}{l}\text { FLUORILEE } \\
\text { (HGLL) }\end{array}$ \\
\hline & & n & 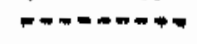 & 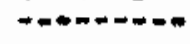 & ט- & ה & 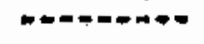 & 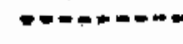 \\
\hline $\begin{array}{c}8 \\
11-J A N=7 B \\
23=M A R=78 \\
20=J U N=78 \\
10-S E P=78\end{array}$ & & & & & $\begin{array}{l}\angle 6,9 E E-03 \\
\angle 6,90 E=03 \\
6, \theta: E=93\end{array}$ & & 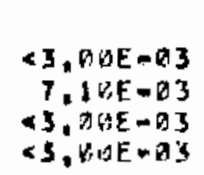 & 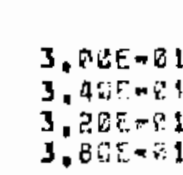 \\
\hline $\begin{array}{cc}8 & 2 \\
11-J A N-78 \\
27-M A R=78 \\
20=J U N=78 \\
12=S E P=78\end{array}$ & & v & $-1.00 E-02$ & $\therefore 1.00 E-02$ & $\begin{array}{l}<6,90 E-03 \\
\times 5,99 E=03 \\
<6,80 E=03\end{array}$ & $9.90 E-82$ & $\begin{array}{r}5,8 U E-03 \\
8,6, E=03 \\
7,4 W E-83 \\
43,20 E=83\end{array}$ & $\begin{array}{l}3.49 E-01 \\
3.29 E-2 ! \\
3.96[-31 \\
4.2 U E-0 !\end{array}$ \\
\hline $\begin{array}{c}B \\
11-J A N-18 \\
24 M M A R=78 \\
20-J U N=78 \\
12-5 E P=7 B\end{array}$ & & & & $\begin{array}{l}1.7 B E=02 \\
3.0 Q E=02\end{array}$ & $\begin{array}{l}\angle 6,96 E=03 \\
\angle 6,90 E=03 \\
\angle 6,80 E=03\end{array}$ & & $\begin{array}{r}4,70 E=03 \\
1,10 E=03 \\
5, B N E=03 \\
<3,0 \Delta E=-23\end{array}$ & 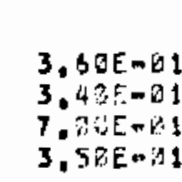 \\
\hline $\begin{array}{l}83 U E 15 A \\
11-J A N=78 \\
21-M A R=78 \\
21=J U N=78 \\
12-8 E F=78\end{array}$ & & & & & 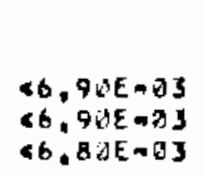 & & $\begin{array}{r}1.0 \Delta E-03 \\
1,3 \Delta E=02 \\
1,20 E-R 2 \\
<3,0 \partial F+\theta 3\end{array}$ & $\begin{array}{l}1.22 E-b 1 \\
1,82[-\pi 1 \\
1,40[-\pi 1 \\
1,805-01\end{array}$ \\
\hline $\begin{array}{l}329 E 12 \\
11=J A N=78 \\
21-M A R=78 \\
21-J U N=78 \\
12 \pi S E P=78\end{array}$ & & & & & $\begin{array}{l}\angle 6.9 \square E-83 \\
\angle 6.94 E-93 \\
<6.80 E=03\end{array}$ & & & $\begin{array}{l}2,60 E-01 \\
3,00 E=01 \\
2,80 E=41 \\
3,40 E-01\end{array}$ \\
\hline $\begin{array}{l}827 E 19 \\
11=J A N=78 \\
98 * 4 A R=78 \\
21=M A R=78 \\
26-A P R=78 \\
17=N A Y=7 B \\
21=J U N=78 \\
11=J U L=78 \\
97=A \cup G=7 B\end{array}$ & & & & & $\begin{array}{l}<6.90 E=03 \\
<6.96 E=03 \\
<6.961 E-03 \\
<6.90 E=03 \\
<6.90 E+0,3 \\
<6,90 E=03\end{array}$ & $1.40 E=01$ & 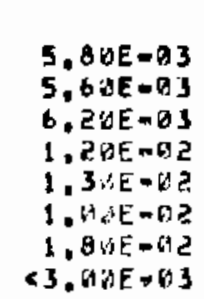 & 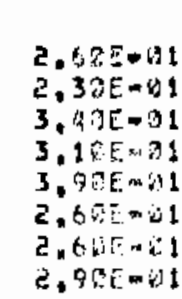 \\
\hline
\end{tabular}


WELL NO

DATE

- S27 E10

15-SEP-78

วด्NOV=?

$6819 E 13$

$12-J A N=78$
$21-H A F-78$

2U-JUN-78

12-SEP-78

- 36 EAG 21 TMAR-TB $26-5 E P-78$

656 E4D

Z1-MAK-78

2i-JUN-70

19-SEP 78

6508

$20-5 E P=1 \theta$

- 901

DSOJANAT 78

21 OMARMIB

$\rightarrow 23$

96-JAN-7S

द I $\triangle M A R=78$

$41,705=02$

25-SEP-7B

- 817

$2 I=M A R-7 B$
CESIUM COBALT URATIUM RUTHENIUM

(PCI/ML)

CHROMIUH

(HG/L)

FLUDPIOE.

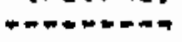

non-nom-a

m-m+nata

$66,8 \mathrm{ijE}=0 \mathrm{G}$

$60,90 E=03$

ct. 9ดE-ด3

$46,90 E+03$

×3. $\triangle G E=Q B 3$

$<3,910 E-03$

$43, A \Delta F \backsim B 3$

$43,000-03$

$2.40 E+01$

5. $20 E-\theta i$

$1.93 E=1$

1. 12EnGI

$46,96 E-B 3$

$46.91 E-63$

$26, a \leq 1 \varepsilon-03$

$<6,9 J E-135$

$46.8 J E=03$

46. 90E-83

$46.90 E=03$

$<6.84 E-03$

$2.1 B E=92$

$<1.50 E-02<1.406-02$

$1.30 E=02$

$1.60 E=01$

3.0SE-01

3. ZXE-DI

3. $52 E-01$

$4,12 \mathrm{E}-9 \mathrm{l}$

$1.40 E-02$ 
MELL NDE

TOTAL ALPHA STRONTIUM
(PEI/ML)
(PCI/ML)

$b \quad 13 \quad 14$ $13-J A N=78$ $19-A P C=18$

$6 \quad 1526$ $23 M M A R=70$ $21-S E P=78$
210

$6 \sum_{13} 5$ $2 B+M A R=7 B$

$6 \quad 1980$ $17-\mathrm{HAY}=7 \mathrm{~B}$

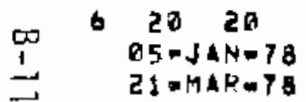
$2 \theta=9 E F-78$

$6 \quad 5859$ $05=J U L=78$

62433 $05-\mathrm{JAN}-76$ $52 \rightarrow M A R=7 B$ $5 C-S E P-78$

b Es 15 $13-J A N=7 B$ $25=M A R-7 B$ $21=S E P=78$

6278 $13-J A N-7 \theta$
CA-HAR- 78
CESIUM COBALT UHANIUM RUTHENIUM $[P[I / M L]$ a*n-..... $(P L I M L)$

(PC $(P, M L)$

\{P[I/HL\}

CHROMIUM

(MO/L)

FLUDR IOE

- (P.)

-oomente-

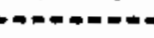

(MG/L)

द. $S A E-Q 21$

$1,00 E-01$

$3.40 E-02$

$3,60 E-02$

$11.50 E 002$

$5.50 E-102$

$1.82 \mathrm{E}-02$

$1,00 E \operatorname{DI} 2$

$3.00 E-01$

2. 8मE०त?

$3,70 E=02$

3,5 B $=52$

$0,60 E-02$

$1.40 E-69$

$1,60 E m 22$

$1,50 E-O Z$

2. BOE-OZ

$\therefore 1,50 E-02$

$5,4 A E=A 2$

$5.50 E \rightarrow D 2$

$3,60 E-72$

2. 60ENOD

$8,20 E-02$

$1,58 E-32$

2.7.7E-6

3.บวE-อ1 


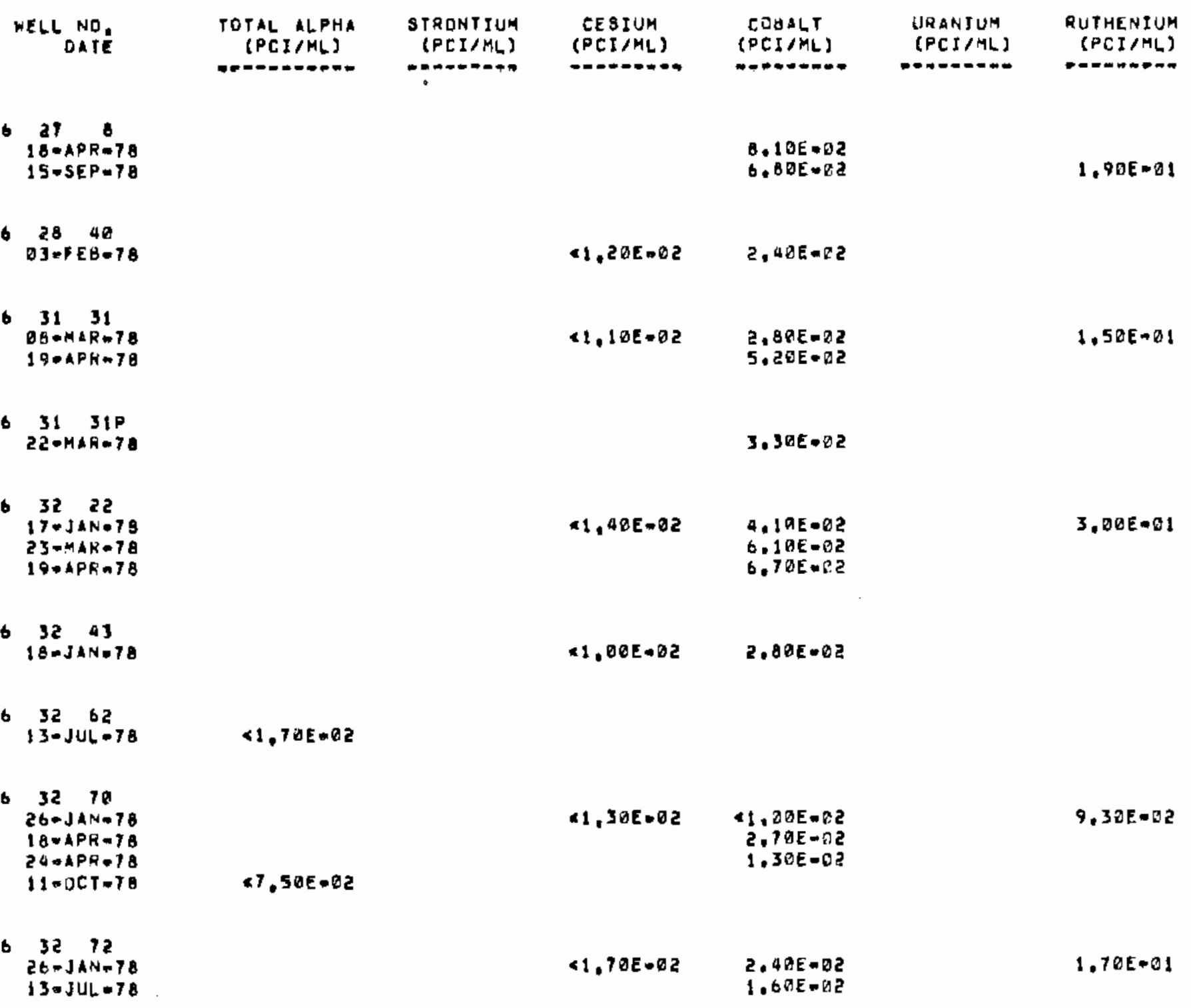




\begin{tabular}{|c|c|c|c|c|c|c|c|c|}
\hline $\begin{array}{l}\text { WELL NOE } \\
\text { OATE }\end{array}$ & $\begin{array}{l}\text { POTAL ALPHA } \\
\text { (PCLAML) }\end{array}$ & $\begin{array}{l}\text { SIPONTIUH } \\
\text { (PCI/HL) }\end{array}$ & $\begin{array}{l}\text { CESIUM } \\
\text { (PCI/ML) } \\
\text { (PC) }\end{array}$ & $\begin{array}{c}\text { CDEALT } \\
(P C I / P L) \\
\forall+\infty+\infty+\infty+\infty\end{array}$ & $\begin{array}{l}\text { URANIUM } \\
\text { (PIISKL) }\end{array}$ & $\begin{array}{l}\text { RUTHENIUH } \\
\text { (PCI } P \text { ML) } \\
\text { P=- }\end{array}$ & $\begin{array}{c}\text { CHAOHIUM } \\
\text { (MEIL) }\end{array}$ & $\begin{array}{c}\text { FLUORIDE } \\
(H E / L)\end{array}$ \\
\hline $\begin{array}{c}3277 \\
31=J A N=78 \\
13=J U L=78 \\
12-0 C Y-78\end{array}$ & & & $\times 1, D 0 F-02$ & $\begin{array}{l}1,60 E=92 \\
1.53 E=02 \\
2.10 E=02\end{array}$ & & $1,1 \mathrm{BE}=01$ & & \\
\hline $\begin{array}{c}33 \quad 42 \\
18-J A N-78 \\
20=A P R=78 \\
2 Z=S E P=78\end{array}$ & & & $41,005-92$ & $\begin{array}{l}1.90 E-92 \\
2.99 E-02 \\
2.00 E-02\end{array}$ & & $\begin{array}{l}8,20 E-02 \\
1,20 E-01\end{array}$ & & \\
\hline $\begin{array}{l}3356 \\
1 B=J A N=78 \\
27-M 4 P-78 \\
05-J U L=78\end{array}$ & & & $41,20 E=02$ & $\begin{array}{l}1.39 E-02 \\
1.59 E-0 ? \\
4.00 E=02\end{array}$ & & $1,20 E=01$ & & \\
\hline $\begin{array}{l}34394 \\
17-34 H-78 \\
21=5 E P-78\end{array}$ & & & $=1,50 E-02$ & $11,59 E=02$ & & $\begin{array}{l}2.90 E-0 ! \\
9.00 E-D 2\end{array}$ & & \\
\hline $\begin{array}{c}3 A 4 Z \\
1 B \rightarrow J \triangle N \rightarrow 18\end{array}$ & & & $41,0 D E-02$ & 4.ZBE-OZ & & $8.00 E-52$ & & \\
\hline $\begin{array}{c}35 \stackrel{9}{15} \\
13-J A N=78 \\
28-M A R=78\end{array}$ & & & $\angle 1,3 B E+102$ & $\begin{array}{l}2.40 E=02 \\
1.80 E=02\end{array}$ & & $1.1 B E-D 1$ & 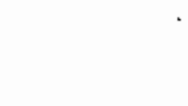 & \\
\hline $\begin{array}{l}3966 \\
1 A=A P R=78 \\
13-J U L=78 \\
11=0 E T=78\end{array}$ & $47.50 E=02$ & & & $\begin{array}{l}2.90 E-92 \\
1.40 E-\$ 2 \\
2.80 E-02\end{array}$ & & & & - \\
\hline $\begin{array}{l}35 \quad 10 \\
26-J A N=78 \\
24-4 P R=78 \\
13-J U L=78 \\
11-0 C T=7 \theta\end{array}$ & & & $<1,50 E=02$ & 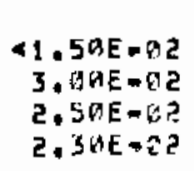 & & $\begin{array}{l}2,30 E-01 \\
4, \text { DEE-D1 } \\
1,60 E-B 1\end{array}$ & & \\
\hline
\end{tabular}




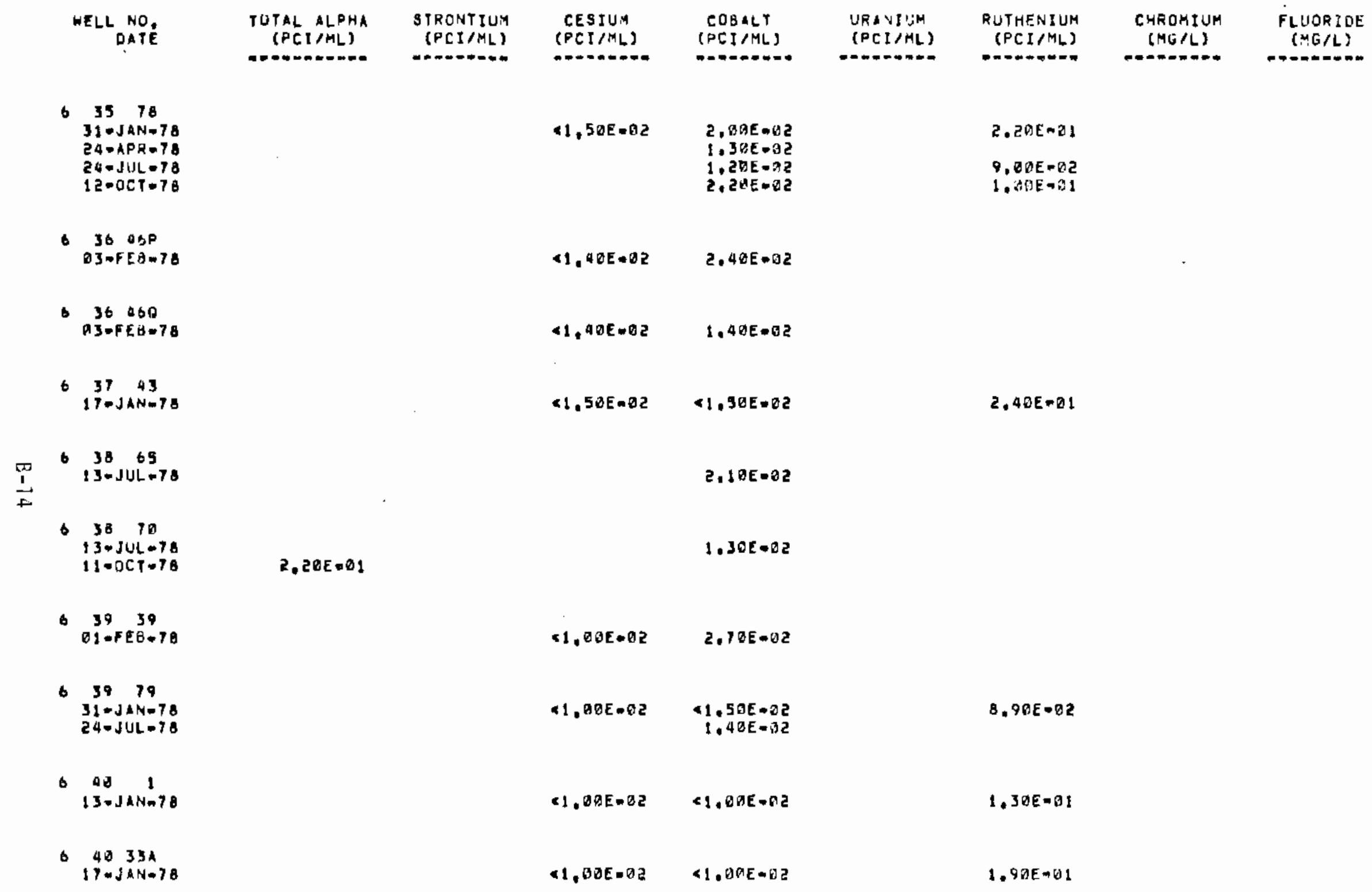




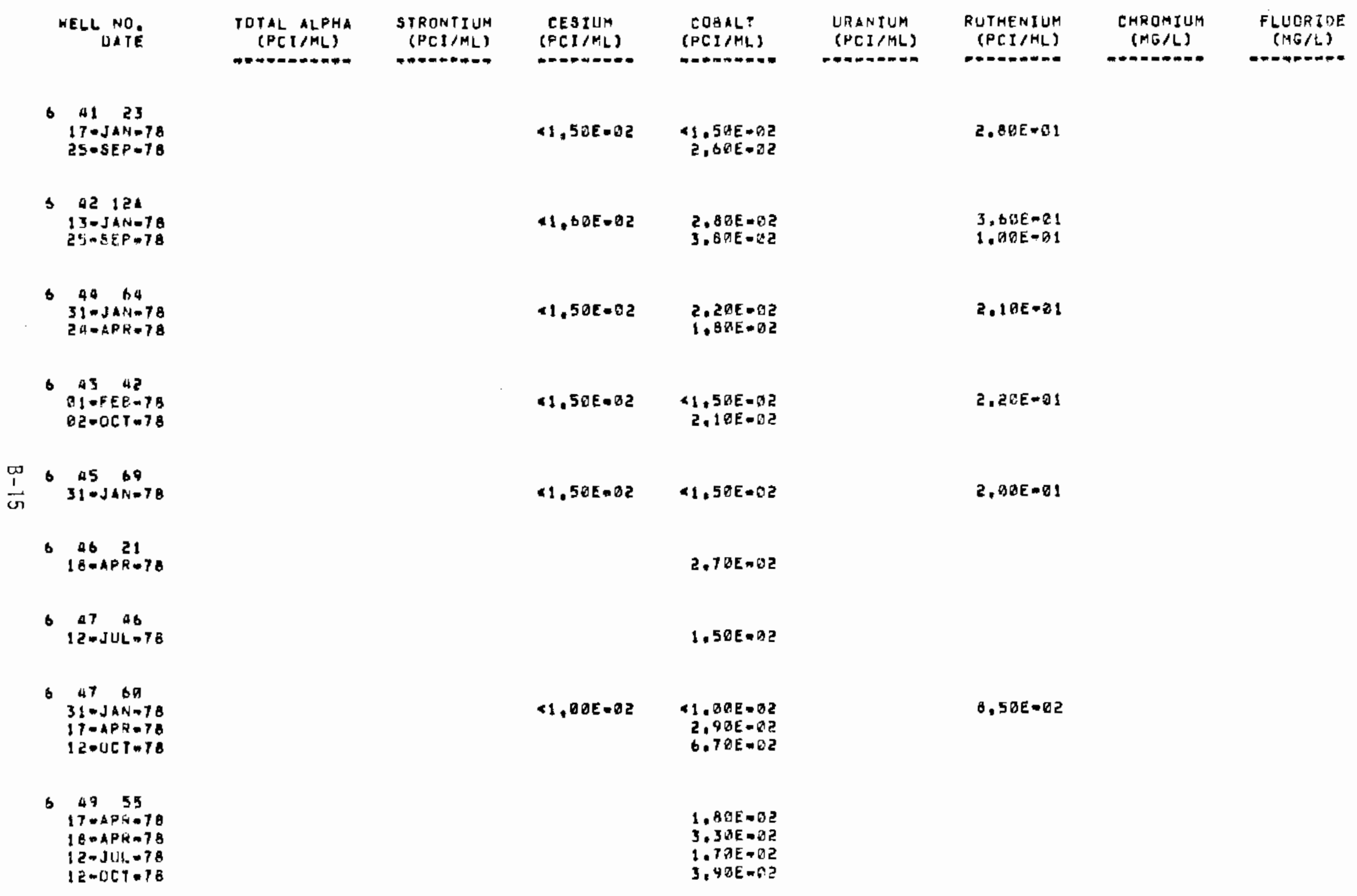




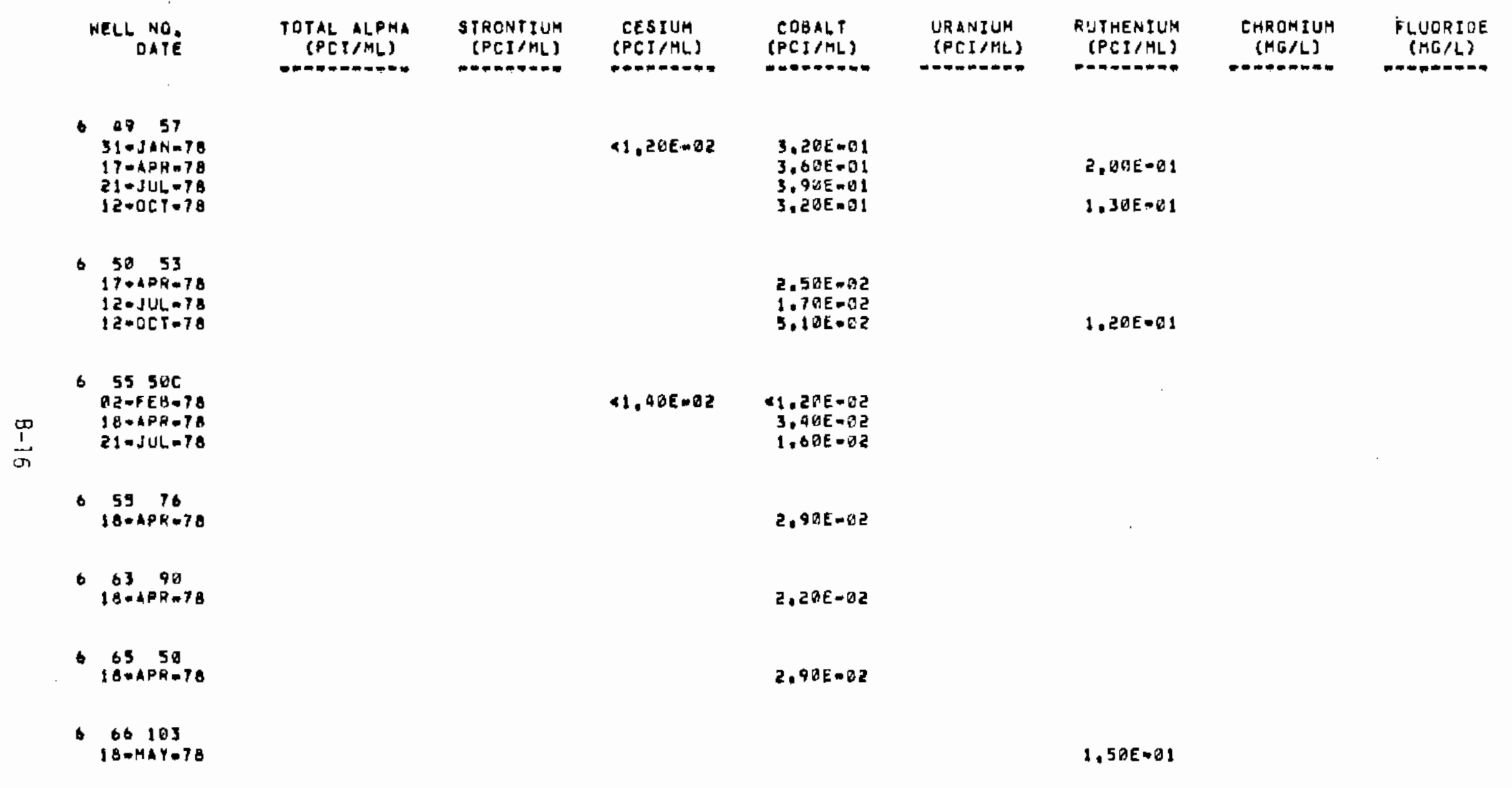


APPENDIX C

C-1 


\section{Chemical and Spectrographic Analyses from Various Wells Sampled}

\begin{tabular}{|c|c|c|c|c|c|c|c|}
\hline Constituents & $\ln i \div 5$ & $699-63-90$ & $699-46-21$ & $099-55-500$ & $699-27-8$ & $699-35-65$ & $699-49-55$ \\
\hline ALK, TOT (AS CACO, ) & $m g / i$ & 120 & 120 & 113 & 123 & 140 & 57 \\
\hline Al uminum & a & 70 & 70 & 50 & 70 & 70. & 130 \\
\hline Antimony & & 30 & 30 & i) & 30 & $.30^{\circ}$ & 30 \\
\hline Arsenic & $. .7 /:$ & 4 & 5 & 5 & 9 & 4 & 11 \\
\hline Barium & g/i & $i \mathrm{i}$ & 50 & $?$ & 50 & 30 & 30 \\
\hline Deryl lium & \lrcorner $G /:$ & $\therefore 1$ & .1 & $i$ & -1 & 1 & .1 \\
\hline Bicarbonate & $m g i$ & 150 & 150 & 130 & 150 & 170 & 59 \\
\hline Bismuth & $\therefore 9 /$ & $\therefore 1.000$ & $\cdot 1,000$ & $.1,000$ & :,000 & i, 853 & 1,000 \\
\hline Boron & $9 /$ & 10 & 10 & in & 30 & 10 & 30 \\
\hline Bromide & mat: & 3.1 & $0 . i$ & 0.1 & 0.1 & 0.1 & $0 . ?$ \\
\hline Cadmidr- & $.9 /:$ & 3 & 3 & 1 & 1 & 1 & 1 \\
\hline Calcitum & तigु/. & 36 & 40 & 23 & 56 & $\because 3$ & 62 \\
\hline Sarbonate & $\operatorname{migh/.}$ & $\hat{\jmath}$ & ก & 9 & ? & 5 & 5 \\
\hline Chloride & $\mathrm{mg} /$. & $\bar{\nexists} .1$ & $1 \%$ & $\therefore 7$ & 11 & 11 & 25 \\
\hline Ehromium & $.9 i$ & 50 & 50 & 30 & 50 & 50 & 50 \\
\hline Chromium Hexavalent & . & ] & 3 & $\ddot{z}$ & $\exists$ & $\hat{3}$ & 3 \\
\hline Coosit & $a /$. & $\vdots$ & 5 & 5 & $\Xi$ & $\Sigma$ & $\Xi$ \\
\hline Solor & & $i$ & $:$ & $i$ & 1 & 3 & 2 \\
\hline Copper & $.9 /$ & 0 & 3 & 了 & 1] & (i & 0 \\
\hline Syantise & / / & 2. 30 & 3.90 & 0.8 & 3. 32 & $0 . \hat{\jmath}$ & 0.70 \\
\hline Fluoride & $70 /$ & 0.2 & 2.5 & 3.2 & 7.3 & i. 6 & 0.5 \\
\hline Gallium & $-9 /$ & 30 & 30 & $3 \pi$ & 30 & 30 & 30 \\
\hline Germanium & $9 /$ & $7 n$ & 70 & $5 c$ & jo & 75 & 50 \\
\hline Hardness Noncarb & $n q /$. & 20 & 43 & $\because$ & 55 & $2 !$ & 130 \\
\hline Hardqes 5 Tota I & $\mathrm{mg} /$ : & 140 & 170 & ?:กิ & 90 & $i 60^{\circ}$ & 190 \\
\hline Iodide & $m g /:$ & 3.90 & 0.31 & 3.70 & ?.1]? & 3.91 & 0.00 \\
\hline Iron & $-9 /$ & 10 & 16 & 3 & 10 & 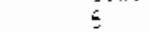 & 7 \\
\hline Iron Ferrous & $.9 i:$ & 10 & 30 & $i i$ & 3 & 3 & - \\
\hline Lead & $.9 /$ & 30 & 30 & 30 & 30 & 30 & 3i) \\
\hline Litnium & $9 /:$ & 7 & 10 & $\vdots$ & 0 & $i$ & 7 \\
\hline Magnesium & $\mathrm{ng} /$. & 13 & 16 & $\therefore ?$ & 13 & 13 & $? . ?$ \\
\hline Mangarese & . & $?$ & 3 & $\vdots$ & : & 30 & 5 \\
\hline Molybdenum & $9 /$ & $\because 气$ & דו̣ו & is o & 15 & 13 & 30 \\
\hline vickel & . $9 /$ & 50 & 50 & 50 & 50 & 50 & $5 \bar{J}$ \\
\hline Nitrate & $\pi q /$. & $\therefore .29$ & 2. & 0.16 & $2 . i$ & 5.5 & 3,7 \\
\hline DH rield & & 7.2 & 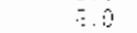 & 7.3 & 7.9 & 7.8 & 3.1 \\
\hline $\mathrm{pH}$ LoO & & $? .9$ & 7.9 & 3.8 & $\therefore 9$ & 7.9 & 5.7 \\
\hline Potass : up & . & $=.7$ & 4.9 & 4.7 & $\overline{0} . \overline{7}$ & 5.9 & $: 2$ \\
\hline Residue faic Sum & $\mathrm{mal}_{\mathrm{O}}$ : & $2: \underline{E}$ & 255 & $\vdots 5 !$ & 252 & $\geq 42$ & 295 \\
\hline Residue Ton/Aft. & & 1]. 29 & 3.53 & ถ. & i), $: 1$ & 5.35 & 3.52 \\
\hline Residue $180 \mathrm{C}$ & $m: g /$ & $2 ! 5$ & 243 & 39 & 302 & 256 & 291 \\
\hline Residue ot $f i]$ losc & $m_{1 ;}$ & 303 & 350 & 150 & $3.0 \hat{\mathrm{j}}$ & 360 & 480 \\
\hline$\triangle A R$ & & 0.: & $\therefore ?$ & 了. & $\because .6$ & 6. & 1.4 \\
\hline Seleniugra & $-9 /$ & i & $\Sigma$ & $\hat{j}$ & $?$ & $\vdots$ & $i 2$ \\
\hline silica & $m g /$ & 42 & $\overline{3}$ & $2 ?$ & 34 & $3 \dot{8}$ & 29 \\
\hline Siver & $. .3 /$ & 10 & i.) & is & 9 & 0 & 10 \\
\hline Sodium & $\operatorname{mg} /$ & $\because \mathrm{i}$ & $2 ?$ & E. : & $2 i$ & 20 & 12 \\
\hline Sotium Percent & & 14 & $2 !$ & 10 & 13 & 37 & 32 \\
\hline So. Conductanca fid. & & $32 n$ & $? 3 ?$ & $\therefore 2$ & $\therefore \equiv i$ & tijo & E说 \\
\hline Sp. Conductance Lao. & & 323 & 395 & 256 & $4: 3$ & .204 & 588 \\
\hline Strontiunt & $.4 \%$ & 1.30 & 50 & 190 & $32 n$ & 00: & 300 \\
\hline S!d fate & $\pi i$. & 25 & $5: 4$ & $\because$ & 13 & 27 & 30 \\
\hline Tin & $3 i$ & 70 & $7 n$ & 50 & $\because$ & 50 & 50 \\
\hline -izanium & $-9 i$ & $\Xi$ & 5 & $\vdots$ & $\vdots$ & 5 & 5 \\
\hline Turbidtiy & $j+1$ & $=$ & $i$ & $i$ & $\vdots$ & 25 & $2 a$ \\
\hline Vח & d & $3 . j$ & בי & 10 & 13 & 30 & 10 \\
\hline sater Temp & 8 & 17.4 & 17.2 & 6.4 & $\dot{r} .+$ & 21.2 & -7.6 \\
\hline Zine & $3 i$ & 5 & 5 & 5 & 3 & 5 & .5 \\
\hline Zirconium & $-9 /$ & 5 & 5 & 5 & $\because$ & $\approx$ & 5 \\
\hline resiur:-?37 & DE: $;$ & 2 & 2 & $\hat{\vdots}$ & - & $?$ & 2 \\
\hline Cobait-60 & $x<i$ & 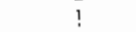 & 1 & 1 & sil & $?$ & 1 \\
\hline sross $8,0,65-137$ & $p C i ;$ & $\hat{6},:$ & 7.5 & 5.2 & $1 ! 3$ & $1:$ & 13 \\
\hline Circss $5,3, S R-9 C$ & $\mathrm{pSi} /$. & $3 . ?$ & $5 . i$ & 45 & It & $2 . i$ & 1.3 \\
\hline Gross Alpna IJ-?AT & . $/$ & $3 . ?$ & i. 3 & $\therefore=$ & $\therefore i$ & 8.2 & $\cdot \hat{L} \hat{L}$ \\
\hline Friticris & 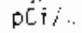 & 480 & $2: .900$ & 490 & 1. 30,90 & 90,500 & 485 \\
\hline Strontisum-90 & pili. & $\therefore .7$ & 1). & 3.4 & .2 .1 & 0.. & .3 .4 \\
\hline
\end{tabular}




\begin{tabular}{|c|c|c|c|c|c|c|c|c|}
\hline Constituents & Units & $699.13-1 \mathrm{~A}$ & $599-14-38$ & $699-33-56$ & $699-50-283$ & $699-50-8$ & $699-32-22$ & $599-34-51$ \\
\hline$A L K, \rightarrow D T \quad\left(\mathrm{~A}_{5} \quad \mathrm{CACO}_{3}\right)$ & $m g / i$ & 130 & 140 & 170 & 130 & 130 & 110 & 160 \\
\hline Al LAR inum & . & 70 & 70 & 70 & 75 & 70 & $: 00$ & 100 \\
\hline Antimony & & 30 & 30 & $: 30$ & 30 & $\therefore 30$ & $<30$ & 30 \\
\hline Arsenic & ..q/: & 14 & 4 & 5 & 7 & 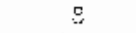 & 5 & 6 \\
\hline Barium & $-g / i$ & 52 & 70 & 70 & 50 & 50 & 50 & 50 \\
\hline Beryllium & $j /$ & $\because 1$ & 1 & $\because 1$ & -1 & $\therefore$ & $\therefore 1$ & 1 \\
\hline Bicarbonate & $\operatorname{mg} /:$ & 160 & 170 & 210 & 160 & 160 & 130 & 200 \\
\hline Bismuth & $-9 / 2$ & $.1,000$ & $\cdot .300$ & 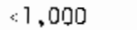 & $\therefore, 000$ & $\cdot 1,300$ & $\therefore 1,000$ & 1,300 \\
\hline Boron & $-g / i$ & 30 & 30 & 30 & 10 & 30 & $3 c$ & 30 \\
\hline Bromide & $\mathrm{mg} / \mathrm{s}$. & 3.1 & D. 1 & 0.1 & 0.1 & 3.1 & 0.1 & 0.1 \\
\hline ìdmi um & - $6 / 1$ & 3 & 3 & 3 & 3 & 3 & 3 & 3 \\
\hline Ca]cium & $\log /$ & 33 & 34 & 47 & 31 & 42 & 50 & 50 \\
\hline Carbonate & $\mathrm{mg} /$. & 0 & 3 & 0 & 0 & 0 & 0 & 0 \\
\hline Chioride & mgi i & 7.7 & 4.2 & 7.3 & ழ. 4 & 11 & 14 & 8.2 \\
\hline Conomitum & $-9 i$ & 50 & $5 i$ & 50 & 50 & 53 & $\therefore 50$ & $50 \hat{v}$ \\
\hline Chroni ur: Hexavalent & $-C / 2$ & 3 & 0 & 6 & 5 & 7 & $\vdots$ & 5 \\
\hline Cobalt & $-\mathrm{g} /$ & .5 & 5 & 5 & 5 & $\Xi$ & $\therefore 5$ & $\therefore$ \\
\hline Color & & & 5 & 2 & $\hat{i}$ & 1 & 2 & 1 \\
\hline Copper & $-9 / 2$ & 0 & $\hat{\jmath}$ & 0 & 3 & 9 & 3 & C \\
\hline Syanide & $n g / ;$ & 0.00 & 5.90 & 0.00 & 0.00 & 3.00 & C. .22 & 0. 35 \\
\hline Fluoride & $\lg /$. & 0.4 & 0.5 & 9.5 & 0.6 & 0.4 & 0.4 & 0.5 \\
\hline Ga 111 um & $0 j$ & .30 & 30 & 30 & 30 & 30 & -30 & $<30$ \\
\hline Germanjum & $g /=$ & $5 \mathrm{C}$ & 70 & 70 & 70 & 70 & 70 & 70 \\
\hline Mardress koncarb & $\operatorname{mg} /:$ & 5 & 3 & 3 & 3 & 23 & 引 & 23 \\
\hline Hardress Total & $\mathrm{mg} /$. & 140 & $: 33$ & 180 & $: 20$ & 150 & 190 & 190 \\
\hline Iodide & $n q i$ & .. .00 & 0.01 & 9.00 & 0.01 & 9. & וניט & 0.00 \\
\hline Iron & $g /$ & .5 & 50 & 7 & $\cdot 5$ & .5 & :0 & $: 0$ \\
\hline Iron Ferrous & $\ddot{q} / x$ & 10 & 20 & 10 & 10 & 10 & 0 & 0 \\
\hline Lead & $. \mathrm{g} / \mathrm{l}$ & -30 & 30 & 30 & 33 & -30 & 30 & 30 \\
\hline Lithi uta & . $g /:$ & 10 & 12 & 10 & 15 & 10 & 7 & 10 \\
\hline Hagnesidum & $7 \mathrm{~g} / \mathrm{s}$ & 13 & $\because$ & 14 & $\because !$ & 12 & 14 & 15 \\
\hline Mąnganese & glo & $i$ & 70 & 3 & 1 & $i$ & 5 & 3 \\
\hline Molyodenur: & $g /$ & הַ1 & 10 & 30 & 30 & $i 2$ & $\$ 0$ & 10 \\
\hline Nickel & ... & 50 & 50 & 50 & 50 & 50 & .50 & .50 \\
\hline Nitrate & $\pi \mathrm{s} i$ & 2.0 & 3.00 & 2.4 & 3.72 & 3.0 & 16.5 & 2.4 \\
\hline pit Field & & 7.5 & 7.3 & $7 . \hat{0}$ & 7.8 & 3.0 & 7.9 & 7.8 \\
\hline $\mathrm{pH}: \mathrm{ab}$ & & 7.8 & 7.8 & 7.9 & 7.8 & 7.8 & 7.8 & 7.7 \\
\hline Potassium & $\mathrm{mg} /:$ & 6.5 & 5.2 & 6.3 & 4.2 & 6. 9 & 6.9 & 5.9 \\
\hline Residue Calc Sum & $\mathrm{mg} /$ : & 232 & 224 & 270 & 221 & 253 & 273 & 296 \\
\hline Residue Ton/Aft & & 0.31 & 1]. & 0.26 & 1. 28 & 0.34 & 0.44 & 0.38 \\
\hline Residue $180 \mathrm{c}$ & mg/. & 225 & 292 & 251 & 28. & 251 & 180 & 270 \\
\hline Residue Tot Fil 105C & $m g /$. & 200 & $22 n$ & 380 & 790 & 370 & 430 & 380 \\
\hline SAR & & 0.8 & 0.6 & 3.8 & 0.9 & 0.8 & 1.0 & 0. ? \\
\hline Selenidum & 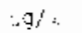 & $?$ & 0 & 2 & 7 & 2 & 1 & 3 \\
\hline Silfca & $\pi \mathrm{m} /$ & 36 & 17 & $4 \hat{6}$ & $3 \bar{i}$ & 57 & 30 & 40 \\
\hline silver & $\pi /$ & .70 & 16 & 10 & 10 & 10 & .11] & 0 \\
\hline Soditimi & $q /:$ & $? 2$ & $\vdots 7$ & 24 & 22 & 22 & 30 & 21 \\
\hline Sodiunt Percent & & 治 & $?$ & 22 & 27 & 23 & 25 & 19 \\
\hline So. Sonductance fld. & & 348 & 300 & 430 & 290 & 390 & $\Xi 2 E$ & 424 \\
\hline So. Sonductance Lab & & 352 & $3 ! 5$ & 427 & $32^{7}$ & 397 & $5 ! 2$ & 436 \\
\hline Strontium & $. . G /:$ & 300 & 00 & 300 & 500 & 300 & 300 & 300 \\
\hline Sulfate & $\because g /$ & 33 & 30 & 33 & 28 & 15 & 51 & 47 \\
\hline Tin & $. .9 /:$ & ? & (1) & 105 & 7 & $-\mathrm{C}$ & $7 \mathrm{~J}$ & 100 \\
\hline$T i \tan i$ um & $.9 /:$ & 5 & $\equiv$ & 5 & $\frac{5}{5}$ & 5 & 5 & .5 \\
\hline Turbidity & 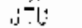 & ) & $?$ & $a$ & 1 & 0 & $\hat{2}$ & i) \\
\hline Vanagri & $-g i i$ & $13 \hat{j}$ & 18 & 30 & $3 \%$ & 10 & $: \overline{0}$ & 30 \\
\hline water emp & $e^{2}$ & 7.4 & $\because 9.2$ & 21.2 & Ig.? & 1.2 .2 & 18.4 & ?].? \\
\hline tine & $\exists /$ & 5 & $\because$ & 10 & 300 & 5 & 5 & 5 \\
\hline Zirconism & . $3 i<$ & $\vdots$ & 5 & 5 & $\Xi$ & 5 & 5 & 5 \\
\hline Cesium-i37 & $p C i /$ & 2 & 2 & ? & $\hat{2}$ & 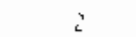 & $?$ & $\therefore 2$ \\
\hline Cota $7 \mathrm{t}-60$ & $\mathrm{ptoij}$ & i & $:$ & 1 & $?$ & 5 & 70 & .1 \\
\hline Gross $3,0,[5-13]$ & $\mathrm{pCi}$ & 3.1 & 3.4 & 5.3 & 1.6 & 16 & 150 & 6.0 \\
\hline Gross $3 . J, S R-30$ & $\mathrm{pCi}$ & 7 & 3.3 & 5.8 & 3.3 & 1 & $:] 0$ & 5.1 \\
\hline Gross A1pha i-i. & $-9 /$. & 11 & 1.4 & 7,3 & 4.3 & 4. 1 & 5.1 & 3.5 \\
\hline Fitium & pCiri. & 170.300 & 435 & 480 & 400 & 72,300 & $1,200,300$ & $\therefore 480$ \\
\hline $5:$ rant: $: 1,90$ & pti: & 3.4 & 0.1 & .0 .4 & .9 & .3 .4 & 2.4 & 3. 4 \\
\hline
\end{tabular}




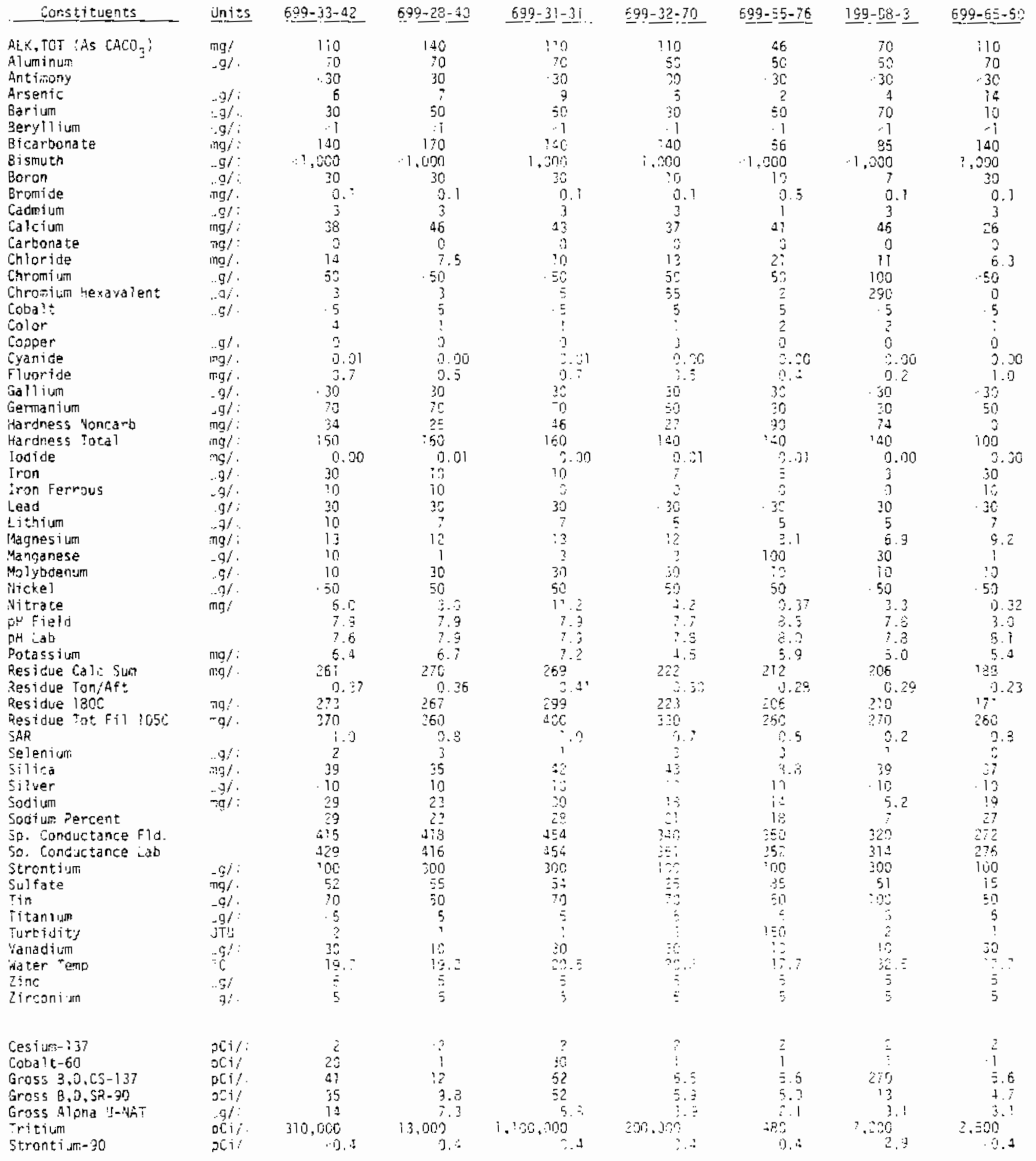


PNL-2899

\section{DISTRIBUTION}

No. of

Copies

OFFSITE

A. A. Churm

DOE Chicago Patent Group

9800 South Cass Avenue

Argonne, IL 60439

D. H. Slade

DOE Division of Biomedical and Environmental Research

Washington, DC 20545

2 G. W. Cunningham

DOE Div. of Waste Management, Production \& Reprocessing

Washington, DC 20545

R. H. Engleken

NRC Directorate of Regiona? Operations, Region $V$

1990 N. California Blvd.,

Suite 202

Walnut Creek, CA 94596

J. D. Griffith

Asst. Dir. of Reactor Development and Technology

Washington, DC 20545

27 DOE Technical Information Center

R. E. Tiller

DOE Idaho Operations

Operationa? Safety Division

Idaho Falls, ID 83401

C. Sherman

DOE Headquarters Library

Mail Station G-043

Washington, DC 20545

4 H. M. MCCOol

DOE Division of Operational and

Environmental Safety

Washington, DC 20545
No. of

Copies

A. A. Schoen

DOE Division of Operational and Environmental Safety

Washington, DC 20545

G. Facer

DOE Div, of Military Applications

Washington, DC 20545

W. J. Larkin

DOE Nevada Operations Office

Office of Safety

P.0. Box 14100

Las Vegas, NV 89114

5 E. Cowan

Environmental Protection Agency Region $X$

Seattle, WA 9810 ]

H. S. Jordan

Los Alamos Scientific Laboratory

Los Alamos, NM 87544

L.8. Day, Director

Oregon State Department of Environmental Quality

1234 SW Morrison

Portland, OR 97205

G. Toombs

Oregon State Health Division

P.D. Box 231

Portland, OR 97207

M. W. Parratt

Oregon State Health Division

P.0. Box 231

Portland, OR 97207

R. R. Mooney

Washington State Department of

Social and Health Services

1514 Smith Tower

Seattle, WA 98104 
No. of

Copies

c. Lewis

Washington State Department of Social and Health Services

P.0. Box 1788, MS 56-1

Olympia, WA 98504

T. Strong

Washington State Department of

Social and Health Services

P.0. Box 1788, MS 56-1

01 ympia, WA 98504

R. C. Will

Washington State Department of Social and Heaith Services

P.0. Box 1788 , MS 56-1

01 ympia, WA 98504

G. L. Fiedier

Washington State Department of Ecology

01ympia, WA 98504

N. G. Hallauer

Washington State Department of Ecology

0lympia, WA 98504

G. Hansen

Washington State Department of Ecology

Olympia, WA 98504

‥ Wallace

Washington State Department of Ecology

Olympia, WA 98504

J. C. Ebert

U.S. Geological Survey

1201 Pacific Ave., Suite 600

Tacoma, WA 98402

V. E. Michael

Benton-Frankl in Health Center

Pasco, WA 99301
No. of

Copies

R. A. Chitwood

Washington Public Power Supply

Systern

3000 George Washington Way

Richland, WA 99352

D. D. Tilson

Washington Public Power Supply

System

3000 George Washington Way

Richland, WA 99352

X. R. Engstrom

City of Richland

Water and Sewer Department

505 Swift Blvd.

Richtand, WA 99352

i1. L. Smith

Exxon Nuclear

Horn Rapids Rd.

Richland, WA 99352

R. H. Poirier

Battelle Memorial Institute

505 King Avenue

Columbus, $\mathrm{OH} 43201$

M. 0. Fretwell

U.S. Geological Survey

345 Middlefield Rd.

Menlo Park, CA 94025

J. B. Robertson

U.S. Geological Survey

345 Middlefield Rd.

Menlo Park, CA 94025

R. D. Paris

Oregon State Health Division

$1400 \mathrm{~S} . \mathrm{W}$. Fifth Avenue

Portland, OR 97201 
No. of

Copies

ONSITE

16 DOE Richland Operations Office

0. J. Elgert (2)

D. R. Elle (5)

R. L. Ferguson

M. G. White (5)

H. E. Ransom

R. E. Gerton

M. H. Tiernan

9 Rockwel 1 Hanford Operations

D. J. Brown

K. Kover

A. L. Law

G. L. Hanson

F. A. Spane

J. V. Panesko (2)

B. J. Saueressig

RHO File

2 Hanford Environmental Health Foundation

L. J. Maas

B. D. Reinert

5 United Nuclear Industries, Inc.
Ho. of

Copies

3 Westinghouse Hanford Company

R. 0 . Budd

G. Carpenter

R. B. Hall

38 Pacific Northwest Laboratory

G. E. Backman

J. R. Berry

P. J. Blumer

P. E. Bramson

D. B. Cearlock

J. P. Cortey

P. A. Eddy (10)

D. W. Dragnich (5)

J. R. Houston

L. J. Kirby

H. V. Larson

N. R. Legato

V. L. McGhan

D. A. Myers

K. R. Price

B. D. Robertson

C. M. Unruh Technical Information (5)

P. E. Bramson--Historical File Publishing Coordinator (2)

La

T. E. Dabrowski

A. E. Engler

E. A. Weakley

W. G. Westover

UNI File 
